\title{
Effects of Fe(III) Oxide Mineralogy and Phosphate on Fe(II) Secondary Mineral Formation during Microbial Iron Reduction
}

\author{
Edward J. O’Loughlin ${ }^{1, *(1)}$, Maxim I. Boyanov ${ }^{1,2}{ }^{(}$, Christopher A. Gorski $^{3,+}{ }^{+}$, Michelle M. Scherer ${ }^{3}$ \\ and Kenneth M. Kemner ${ }^{1}$ (D) \\ 1 Biosciences Division, Argonne National Laboratory, Lemont, IL 60439-4843, USA; \\ mboyanov@anl.gov (M.I.B.); kemner@anl.gov (K.M.K.) \\ 2 Institute of Chemical Engineering, Bulgarian Academy of Sciences, 1113 Sofia, Bulgaria \\ 3 Department of Civil and Environmental Engineering, University of Iowa, Iowa City, IA 52242-1527, USA; \\ gorski@psu.edu (C.A.G.); michelle-scherer@uiowa.edu (M.M.S.) \\ * Correspondence: oloughlin@anl.gov; Tel.: +1-630-252-9902 \\ + Present address: Department of Civil and Environmental Engineering, The Pennsylvania State University, \\ University Park, State College, PA 16802-7304, USA.
}

check for updates

Citation: O'Loughlin, E.J.; Boyanov, M.I.; Gorski, C.A.; Scherer, M.M.; Kemner, K.M. Effects of Fe(III) Oxide Mineralogy and Phosphate on Fe(II) Secondary Mineral Formation during Microbial Iron Reduction. Minerals 2021, 11, 149. https://doi.org/ $10.3390 / \min 11020149$

Academic Editor: Malin Bomberg Received: 29 December 2020

Accepted: 27 January 2021

Published: 31 January 2021

Publisher's Note: MDPI stays neutral with regard to jurisdictional claims in published maps and institutional affiliations.

Copyright: (c) 2021 by the authors. Licensee MDPI, Basel, Switzerland. This article is an open access article distributed under the terms and conditions of the Creative Commons Attribution (CC BY) license (https:// creativecommons.org/licenses/by/ $4.0 /)$.

\begin{abstract}
The bioreduction of Fe(III) oxides by dissimilatory iron-reducing bacteria may result in the formation of a suite of $\mathrm{Fe}(\mathrm{II})$-bearing secondary minerals, including magnetite (a mixed $\mathrm{Fe}(\mathrm{II}) / \mathrm{Fe}(\mathrm{III})$ oxide), siderite (Fe(II) carbonate), vivianite (Fe(II) phosphate), chukanovite (ferrous hydroxy carbonate), and green rusts (mixed $\mathrm{Fe}(\mathrm{II}) / \mathrm{Fe}(\mathrm{III})$ hydroxides). In an effort to better understand the factors controlling the formation of specific Fe(II)-bearing secondary minerals, we examined the effects of $\mathrm{Fe}(\mathrm{III})$ oxide mineralogy, phosphate concentration, and the availability of an electron shuttle (9,10-anthraquinone-2,6-disulfonate, AQDS) on the bioreduction of a series of Fe(III) oxides (akaganeite, feroxyhyte, ferric green rust, ferrihydrite, goethite, hematite, and lepidocrocite) by Shewanella putrefaciens CN32, and the resulting formation of secondary minerals, as determined by X-ray diffraction, Mössbauer spectroscopy, and scanning electron microscopy. The overall extent of $\mathrm{Fe}(\mathrm{II})$ production was highly dependent on the type of Fe(III) oxide provided. With the exception of hematite, AQDS enhanced the rate of Fe(II) production; however, the presence of AQDS did not always lead to an increase in the overall extent of $\mathrm{Fe}$ (II) production and did not affect the types of $\mathrm{Fe}$ (II)-bearing secondary minerals that formed. The effects of the presence of phosphate on the rate and extent of $\mathrm{Fe}(\mathrm{II})$ production were variable among the $\mathrm{Fe}(\mathrm{III})$ oxides, but in general, the highest loadings of phosphate resulted in decreased rates of Fe(II) production, but ultimately higher levels of $\mathrm{Fe}(\mathrm{II})$ than in the absence of phosphate. In addition, phosphate concentration had a pronounced effect on the types of secondary minerals that formed; magnetite and chukanovite formed at phosphate concentrations of $\leq 1 \mathrm{mM}$ (ferrihydrite), < 100 $\mu \mathrm{M}$ (lepidocrocite), $500 \mu \mathrm{M}$ (feroxyhyte and ferric green rust), while green rust, or green rust and vivianite, formed at phosphate concentrations of $10 \mathrm{mM}$ (ferrihydrite), $\geq 100 \mu \mathrm{M}$ (lepidocrocite), and $5 \mathrm{mM}$ (feroxyhyte and ferric green rust). These results further demonstrate that the bioreduction of Fe(III) oxides, and accompanying Fe(II)-bearing secondary mineral formation, is controlled by a complex interplay of mineralogical, geochemical, and microbiological factors.
\end{abstract}

Keywords: green rust; siderite; magnetite; chukanovite; vivianite; dissimilatory iron reduction; iron oxide

\section{Introduction}

Iron(III) oxides-a term which we use to include formal Fe oxides, oxyhydroxides, and hydroxides-are common constituents of soils and sediments and are present in a variety of mineralogical forms, including ferrihydrite, goethite $(\alpha-\mathrm{FeOOH})$, akaganeite $(\beta-\mathrm{FeOOH})$, lepidocrocite $(\gamma-\mathrm{FeOOH})$, feroxyhyte $\left(\delta^{\prime}-\mathrm{FeOOH}\right)$, hematite $\left(\alpha-\mathrm{Fe}_{2} \mathrm{O}_{3}\right)$, and maghemite $\left(\gamma-\mathrm{Fe}_{2} \mathrm{O}_{3}\right)$. The biogeochemistry of $\mathrm{Fe}$ in most aquatic and terrestrial environments is 
driven largely by microbial activity, and the presence of Fe(II) in near surface suboxic and anoxic environments is typically the result of the activity of iron(III)-reducing bacteria (IRB) and archaea. These phylogenetically diverse microorganisms couple the oxidation of an electron donor (organic compounds or molecular hydrogen, $\mathrm{H}_{2}$ ) to the reduction of $\mathrm{Fe}(\mathrm{III})$ to $\mathrm{Fe}(\mathrm{II})$ [1-15]. The Fe(II), resulting from the microbial reduction of Fe(III) oxides, can be present as a broad range of $\mathrm{Fe}(\mathrm{II})$ species, including soluble and adsorbed $\mathrm{Fe}(\mathrm{II})$ and mineral phases containing structural $\mathrm{Fe}(\mathrm{II})$ (e.g., magnetite $\left(\mathrm{Fe}_{3} \mathrm{O}_{4}\right)$, siderite $\left(\mathrm{FeCO}_{3}\right)$, vivianite $\left[\mathrm{Fe}_{3}\left(\mathrm{PO}_{4}\right)_{2} \cdot 8 \mathrm{H}_{2} \mathrm{O}\right]$, green rust, chukanovite $\left[\mathrm{Fe}_{2}(\mathrm{OH})_{2} \mathrm{CO}_{3}\right]$, and $\mathrm{Fe}(\mathrm{II})$-bearing clays) [16-25].

Many factors have been identified as contributing to the formation of specific $\mathrm{Fe}(\mathrm{II})$ bearing secondary minerals during the microbial reduction of Fe(III) oxides, including $\mathrm{Fe}(\mathrm{III})$ oxide mineralogy [19,25,26]; Fe(III) oxide particle aggregation [27]; the presence of electron shuttles [17]; the rate and extent of Fe(II) production [17,19,28-30]; the extent of Fe(II) sorption on the parent Fe(III) oxide [25]; the species of IRB and the number of cells present [31-33]; the concentration and type of electron donor [34-37]; the type of organic matter present (including humic substances and microbially-produced extracellular polymeric materials) $[31,33,38]$; and the presence of phosphate and other oxyanions (silicate, molybdate, arsenate, etc.) [17,31,39-41].

Under the conditions typical of near surface aquatic and terrestrial environments, Fe(III) oxides are relatively insoluble, which makes their use as terminal electron acceptors for anaerobic respiration more challenging than for soluble terminal electron acceptors that are easily transported into the cell (e.g., molecular oxygen, nitrate, sulfate, etc.). Some IRB utilize outer-membrane reductases [42] or electrically conductive structures (often described as nanowires) $[43,44]$ to transfer electrons to Fe(III) oxides via direct physical contact with the oxide surface. The need for physical contact with the Fe(III) oxide can be readily overcome by the use of soluble compounds or materials that can be reversibly oxidized and reduced, often called electron transfer mediators or electron shuttles. The oxidized form of the electron shuttle can be reduced by the organism, and then, in its reduced form, can transfer electrons to the Fe(III) oxide at a distance, and is thus reoxidized. Due to the fact that electron shuttles can be cycled repeatedly, the presence of even relatively low concentrations of electron shuttles can have a substantial effect on Fe(III) oxide reduction. A wide variety of organic and inorganic compounds (both endogenous and exogenous) have been shown to function as electron shuttles in the bioreduction of Fe(III) oxides, including humic and fulvic acids [45-50]. The ability of humic substances to act as electron shuttles has largely been attributed to quinone groups within their structures, [51-53] and model quinones, such as 9,10-anthraquinone2,6-disulfonate (AQDS), have been widely used as analogs for quinone groups in humic substances $[17,45,54,55]$.

In soils and sediments, phosphate is commonly found in association with Fe(III) oxides. The interactions between phosphate and Fe(III) oxides in aquatic and terrestrial systems are highly dynamic and involve multiple processes, including adsorption/desorption, the precipitation/dissolution of surface Fe-phosphate phases, and the occlusion/incorporation of phosphate within Fe(III) oxides [56,57]. Indeed, the interactions of phosphate with $\mathrm{Fe}(\mathrm{III})$ oxides has significant effects on the mineralization pathways of Fe phases during $\mathrm{Fe}$ redox transformations [58-64]. Several studies have shown a close association between the presence of phosphate and the formation of green rust during the reduction of ferrihydrite, lepidocrocite, and akaganeite by IRB [17,31,40,65-67].

Green rusts are layered Fe(II)-Fe(III) hydroxides with a pyroaurite-type structurei.e., alternating positively charged $\mathrm{Fe}(\mathrm{II})-\mathrm{Fe}(\mathrm{III})$ hydroxide layers and hydrated anion layers with the general composition $\left[\mathrm{Fe}_{4}^{\mathrm{II}} \mathrm{Fe}_{2}(\mathrm{OH})_{12}\right]^{2+}\left[(A)_{2 / n} y \mathrm{H}_{2} \mathrm{O}\right]^{2-}$, where $A$ is an $n$-valent anion (e.g., $\mathrm{Cl}^{-}, \mathrm{SO}_{4}{ }^{2-}$, or $\mathrm{CO}_{3}{ }^{2-}$ ) and $y$ denotes varying amounts of interlayer water ( $y=2$ to 4 ). They are found in $\mathrm{Fe}(\mathrm{II})$-Fe(III) transition zones in a variety of aquatic and terrestrial environments, including groundwater [68,69], surface waters [70], soils [71-76], and sediments [77-79]. In these environments, green rust minerals, such as 
fougérite, trébeurdenite, and mössbauerite [80-82], may play a central role in Fe redox cycling. Despite their importance in Fe biogeochemistry (including a possible role in the emergence of life on Earth [83]), many questions remain about the processes leading to their formation during microbial Fe(III) reduction, including the role(s) of phosphate and Fe(III) oxide mineralogy.

In this study, we examine the effects of Fe(III) oxide mineralogy (in the presence and absence of an electron shuttle) and the presence of phosphate on the bioreduction of hematite, goethite, maghemite, ferrihydrite, lepidocrocite, feroxyhyte, and ferric green rust by the Shewanella putrefaciens strain CN32, an IRB isolated from subsurface sediment [84], and the subsequent formation of secondary minerals using X-ray diffraction (XRD), ${ }^{57} \mathrm{Fe}$ Mössbauer spectroscopy, and scanning electron microscopy (SEM).

\section{Materials and Methods}

\subsection{Fe(III) Oxides}

Ferrihydrite was prepared by titrating $0.5 \mathrm{M} \mathrm{FeCl}_{3}$ to $\mathrm{pH} 7.5$ via the dropwise addition of $1.0 \mathrm{M} \mathrm{KOH}$ with continuous mixing, which is based on the procedure described by Schwertmann and Cornell [85]. Goethite was synthesized by aging ferrihydrite under alkaline conditions at $70^{\circ} \mathrm{C}$ for $60 \mathrm{~h}$ [85]. Hematite was synthesized by the forced hydrolysis of a $0.02 \mathrm{M}$ solution of $\mathrm{FeCl}_{3}$ in $0.002 \mathrm{M} \mathrm{HCl}$ at $98{ }^{\circ} \mathrm{C}$ for 10 days [85]. Lepidocrocite was synthesized by the air oxidation of a ferrous chloride solution using a modified version of the procedure in Schwertmann and Cornell [85]. Briefly, $30 \mathrm{~g}$ of $\mathrm{FeCl}_{2} \cdot 4 \mathrm{H}_{2} \mathrm{O}$ was dissolved in $900 \mathrm{~mL}$ of water and the resulting solution was filtered through a $0.2 \mu \mathrm{m}$ nylon filter to remove any $\mathrm{Fe}(\mathrm{III})$ solids present. The $\mathrm{pH}$ of the solution was adjusted to 6.0 with $0.5 \mathrm{M} \mathrm{NaOH}$ and the resulting blue/green suspension was sparged with air. The $\mathrm{pH}$ of the suspension was maintained at $\mathrm{pH} 5.5-6.0$ by the dropwise addition of $0.5 \mathrm{M} \mathrm{NaOH}$ until base consumption ceased $(\sim 1 \mathrm{~h})$. Maghemite was prepared by heating lepidocrocite at $190^{\circ} \mathrm{C}$ under an ambient atmosphere for $4 \mathrm{~h}$ followed by $1 \mathrm{~h}$ at $240^{\circ} \mathrm{C}$. Feroxyhyte was prepared by the rapid oxidation of $\mathrm{Fe}(\mathrm{OH})_{2}$ by hydrogen peroxide. Briefly, in a glove box containing an anoxic atmosphere (Coy Laboratory Products, Grass Lake, Michigan, 3-5\% $\mathrm{H}_{2}$ in $\mathrm{N}_{2}$ and $\mathrm{Pd}$ catalyst to maintain $\mathrm{O}_{2}$ in the box $\left.<1 \mathrm{ppm}\right), 400 \mathrm{~mL}$ of $0.5 \mathrm{M} \mathrm{FeSO}_{4}$ was titrated to $\mathrm{pH} 6.5$ with anoxic $1.0 \mathrm{M} \mathrm{NaOH}$ to remove $\mathrm{Fe}(\mathrm{III})$, which precipitated as green rust and was subsequently removed by filtration. The filtered $0.5 \mathrm{M} \mathrm{Fe}$ (II) solution was then titrated to $\mathrm{pH} 12$, which was accompanied by the precipitation of $\mathrm{Fe}(\mathrm{OH})_{2}$ (white rust). The white rust suspension was removed from the glove box and $100 \mathrm{~mL}$ of $40 \%$ $\mathrm{H}_{2} \mathrm{O}_{2}$ was immediately added with rapid mixing on a magnetic stirplate, resulting in the near instantaneous formation of reddish brown feroxyhyte. Ferric carbonate green rust was prepared as described by Latta et al. [86]. Subsequent to synthesis, all phases (except maghemite) were repeatedly washed by centrifugation and resuspension in $\mathrm{ddH}_{2} \mathrm{O}$, then dried at $60{ }^{\circ} \mathrm{C}$ and ground to pass a 200-mesh sieve; ferrihydrite was washed, but not dried (to avoid the irreversible agglomeration of ferrihydrite particles).

The specific surface areas of the iron oxides were determined by multipoint Brunauer, Emmett, and Teller (BET) analysis of $\mathrm{N}_{2}$ adsorption with a Micromeritics Tristar II Surface Area Analyzer (Micromeritics Instruments Corporation, Norcross, GA, USA); all samples were degassed under vacuum $(50 \mathrm{mTorr})$ at $30{ }^{\circ} \mathrm{C}$ for at least $30 \mathrm{~h}$ prior to analysis. The morphology of the iron oxide crystals was examined by scanning electron microscopy (SEM). Samples for SEM were prepared by depositing $~ 500 \mu \mathrm{L}$ of an aqueous suspension of the iron oxide on aluminum specimen mounts, allowing the solids to settle, removing the overlying liquid with a pipette, and drying the solids under an ambient atmosphere before imaging on a Hitachi S-4700-II FEG-SEM (Hitachi High-Technologies Corporation, Tokyo, Japan). The identities of the iron oxides were confirmed by powder X-ray diffraction (pXRD) with a Rigaku MiniFlex X-ray diffractometer (Rigaku Corporation, Tokya, Japan) using $\mathrm{Ni}$-filtered $\mathrm{Cu} \mathrm{K} \alpha$ radiation, scanned between $5^{\circ}$ and $80^{\circ} 2 \theta$ at a speed of $0.1^{\circ} 2 \theta \cdot \mathrm{min}^{-1}$. The XRD patterns were analyzed with the JADE 9 software package (MDI, Livermore, CA, USA) to remove the background through polynomial fitting and the $\mathrm{K} \alpha_{2}$ components. 


\subsection{Bioreduction Experiments}

The bioreduction experiments were conducted in sterile $160 \mathrm{~mL}$ serum bottles containing $100 \mathrm{~mL}$ of sterile defined mineral medium (DMM) [55] with $80 \mathrm{mM} \mathrm{Fe(III)} \mathrm{in} \mathrm{the}$ form of the corresponding Fe(III) oxide, $75 \mathrm{mM}$ formate as the electron donor, phosphate (0-10 mM depending on the experimental system), and $100 \mu \mathrm{M}$ AQDS as an electron shuttle in AQDS-amended systems. The DMM was prepared by combining all components (except the electron donor, phosphate, and AQDS), and the $\mathrm{pH}$ was adjusted to 7.5 by titration with $1 \mathrm{M} \mathrm{NaOH}$, portioned into serum bottles, and autoclaved. After the medium cooled to ambient temperature, the electron donor, phosphate, and AQDS were added from filter-sterilized stock solutions; all systems amended with phosphate also contained AQDS. The bottles were sealed with rubber septa and aluminum crimp caps and made anoxic by sparging with sterile argon. All experimental systems were prepared in duplicate. After $24 \mathrm{~h}$, a $2 \mathrm{~mL}$ sample of suspension was removed from each of the bottles that had been amended with phosphate to determine the extent of phosphate uptake by the Fe(III) oxides. The sample was filtered through a $0.22 \mu \mathrm{m}$ nylon filter and the filtrate was saved for the measurement of phosphate concentration. The inoculum was prepared from latelog-phase cultures of S. putrefaciens CN32 (American Type Culture Collection BAA-543), as described by $\mathrm{O}^{\prime}$ Loughlin et al. [12]. Experiments were initiated by spiking each bottle with the volume of inoculum needed to achieve a cell density of $\sim 5 \times 10^{9}$ cells $\mathrm{mL}^{-1}$. The bottles were placed on a roller drum and incubated at $30^{\circ} \mathrm{C}$ in the dark. Samples of the suspensions-for monitoring $\mathrm{Fe}$ (II) production, as well as for the identification of secondary minerals by pXRD, SEM, and ${ }^{57} \mathrm{Fe}$ Mössbauer spectroscopy-were collected with sterile syringes. Unless otherwise indicated, sample collection and processing were conducted in a glove box containing an anoxic atmosphere.

\subsection{Analytical Methods}

The reduction of Fe(III) was monitored by measuring the total Fe(II) content of $0.75 \mathrm{M}$ $\mathrm{HCl}$ extracts of the suspensions (Fe(II) $)_{\text {tot }}$, referred to hereafter as $\mathrm{Fe}(\mathrm{II})$ ). Samples for Fe(II) analysis were prepared by adding $0.75 \mathrm{~mL}$ of anoxic $1 \mathrm{M} \mathrm{HCl}$ to $0.25 \mathrm{~mL}$ of suspension (the addition of $100 \mu \mathrm{L}$ of concentrated $\mathrm{HCl}$ to samples containing magnetite was needed to ensure the dissolution of all $\mathrm{Fe}(\mathrm{II})$ phases). After 1 week, the samples were centrifuged at $25,000 \times g$ for $10 \mathrm{~min}$. The Fe(II) concentrations in the supernatants were determined by the ferrozine assay [87]. Briefly, $1 \mathrm{~mL}$ of HEPES-buffered ferrozine reagent [88] was added to $50 \mu \mathrm{L}$ of supernatant, and the absorbance at $562 \mathrm{~nm}$ was measured. Phosphate concentration was determined by inductively coupled plasma-optical emission spectroscopy using a Perkin Elmer 4300DV instrument.

Changes in the mineralogy of the suspensions were monitored by pXRD with a Rigaku MiniFlex X-ray diffractometer with Ni-filtered $\mathrm{Cu} K \alpha$ radiation. Samples for $\mathrm{pXRD}$ analysis were collected by filtration on $25 \mathrm{~mm}$ diameter, $0.22 \mu \mathrm{m}$ nylon filters and covered with $8.4 \mu \mathrm{m}$ thick Kapton ${ }^{\circledR}$ film under anoxic conditions. Although the pXRD analysis was conducted under ambient atmosphere, samples prepared in this manner showed no evidence of oxidation when scanned between $5^{\circ}$ and $80^{\circ} 2 \theta$ at a speed of $1.25^{\circ} 2 \theta \mathrm{min}^{-1}$. The pXRD patterns were analyzed with the JADE 7 software package (MDI, Livermore, CA, USA) to remove the background through polynomial fitting and also to remove the $\mathrm{K}_{\alpha 2}$ components.

Samples for SEM imaging were prepared by placing $500 \mu \mathrm{L}$ of suspension on aluminum specimen mounts, allowing the solids to settle, removing the overlying liquid with a pipette, and drying the film of solids in a glove box. Specimens were briefly $(<30 \mathrm{~s})$ exposed to air during transfer to the Hitachi S-4700-II FEG-SEM.

Transmission Mössbauer spectroscopy was performed with a variable temperature He-cooled system with a 1024 channel detector. The ${ }^{57} \mathrm{Co}$ source used $(\sim 50 \mathrm{mCi})$ was in a $\mathrm{Rh}$ matrix at room temperature. All center shifts reported are relative to an $\alpha$-Fe foil at room temperature. Samples were prepared by filtering the cell suspension (approx. $4 \mathrm{~mL}$ ) in an anoxic glove box with recoverable filter paper. The filter paper was then sealed between 
two pieces of $5 \mathrm{~mm}$ Kapton tape to avoid oxidation while the sample was mounted. No indication of inadvertent oxidation was observed. Spectral fitting was done using Recoil Software (version 1.01998, University of Ottawa, Ottawa, ON, Canada). Voigt-based fitting was used to model the spectra to determine the hyperfine parameters and the relative areas between phases. The Lorentzian linewidth was held at $0.12 \mathrm{~mm} \cdot \mathrm{s}^{-1}$, as it was the linewidth measured on the spectrometer for an ideally thick $\alpha$-Fe foil. The relative peak areas (1:1 for doublets, 3:2:1:1:2:3 for sextets) were held constant throughout fitting. Each phase was fitted with only a single component (i.e., multiple $\mathrm{QS}$ and $\mathrm{H}$ distributions were not allowed for a single phase in fitting).

\section{Results}

\subsection{Fe(III) Oxide Bioreduction}

The rate and extent of bioreduction of the Fe(III) oxides varied substantially based on mineralogy (Figure 1 and Table 1). Within $~ 80$ days, only 3\% (on a mol Fe(III) basis) of hematite and $10 \%$ of goethite were reduced, compared to $58 \%$ of maghemite, $57 \%$ of ferrihydrite, and $49 \%$ of ferric green rust. The intermediate reduction of $36 \%, 32 \%$, and $30 \%$ of added Fe(III) occurred for akaganeite, lepidocrocite, and feroxyhyte, respectively. The rate of Fe(III) oxide bioreduction was poorly correlated with oxide surface area (Figure 2). These results are consistent with previous studies showing that highly crystalline phases, such as hematite and goethite, are less bioavailable for microbial iron reduction than less crystalline phases, such as ferrihydrite and lepidocrocite [26,84,89-91].
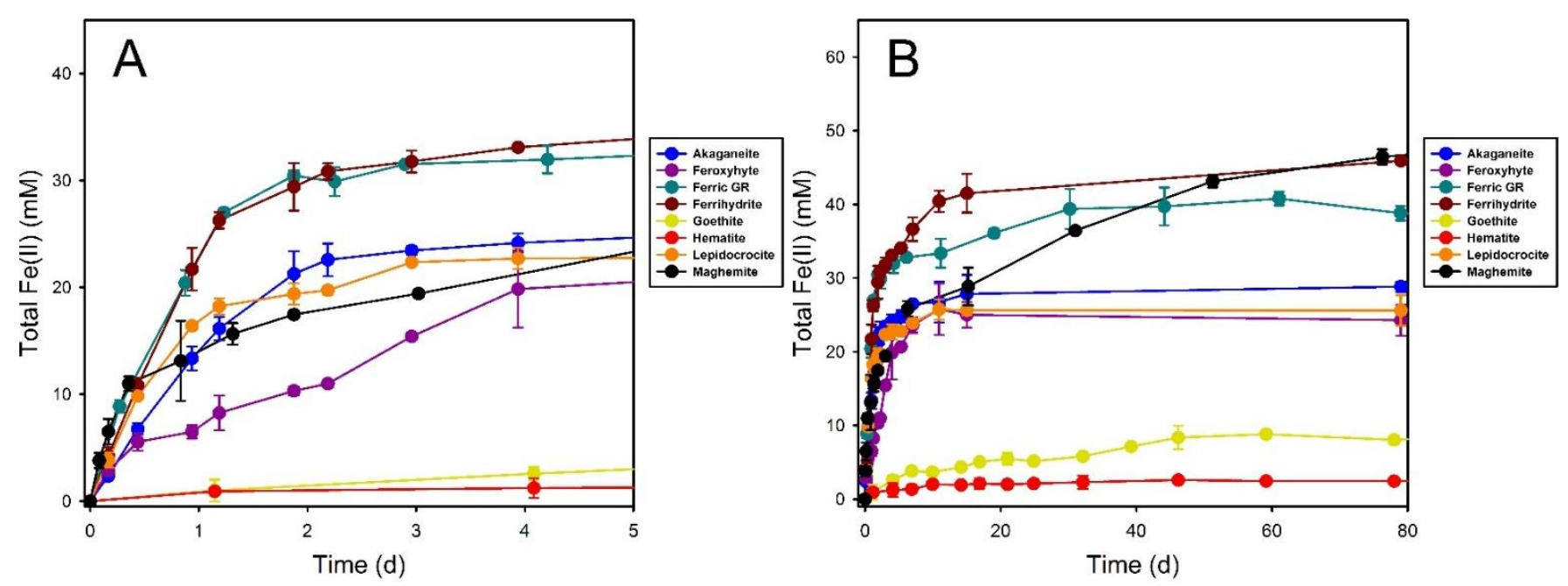

Figure 1. (A) Initial (<5 days) Fe(II) production during the bioreduction of Fe(III) oxides by S. putrefaciens CN32 and (B) over a period of $\sim 80$ days. Data for akaganeite are from O'Loughlin et al. [67].

Table 1. Surface area, Fe(II) production, and maximum Fe(II) production rates.

\begin{tabular}{|c|c|c|c|}
\hline System & Surface Area $(\mathrm{SA}) \mathrm{m}^{2} \cdot \mathrm{g}^{-1}$ & $\mathrm{Fe}(\mathrm{II})_{\text {tot }}{ }^{\mathrm{a}} \mathrm{mM}$ & $\mathrm{Fe}(\mathrm{II})_{\text {tot }}$ Production During Bioreduction ${ }^{\mathrm{b}} \mathrm{mM} \cdot \mathrm{day}^{-1}$ \\
\hline Akaganeite ${ }^{\mathrm{c}}$ & $30.66 \pm 0.33$ & $28.8 \pm 0.7$ & $13.7 \pm 4.3$ \\
\hline Feroxyhyte & $63.85 \pm 0.83$ & $24.3 \pm 2.0$ & $4.15 \pm 0.23$ \\
\hline Ferric Green Rust & $91.52 \pm 1.2$ & $38.8 \pm 1.0$ & $21.3 \pm 1.7$ \\
\hline Ferrihydrite & $290 \pm 0.0^{\mathrm{d}}$ & $45.9 \pm 0.6$ & $22.1 \pm 0.6$ \\
\hline Goethite & $51.13 \pm 0.61$ & $8.0 \pm 0.6$ & $0.60 \pm 0.09$ \\
\hline Hematite & $21.93 \pm 0.21$ & $2.4 \pm 0.2$ & $0.17 \pm 0.08$ \\
\hline Lepidocrocite & $73.13 \pm 0.76$ & $25.6 \pm 0.7$ & $22.4 \pm 0.3$ \\
\hline Maghemite & $79.81 \pm 0.68$ & $46.4 \pm 1.0$ & $30.1 \pm 3.4$ \\
\hline
\end{tabular}

${ }^{a}$ At $\sim 80$ days after inoculation. ${ }^{\mathrm{b}} \mathrm{Fe}(\mathrm{II})$ production rates were calculated by linear regression using least-squares regression of the data during the period of maximum sustained Fe(II) production. ${ }^{c}$ Data for akaganeite are from O'Loughlin et al. [67]. ${ }^{d}$ The value for the surface area of ferrihydrite is from Roden [90]. 


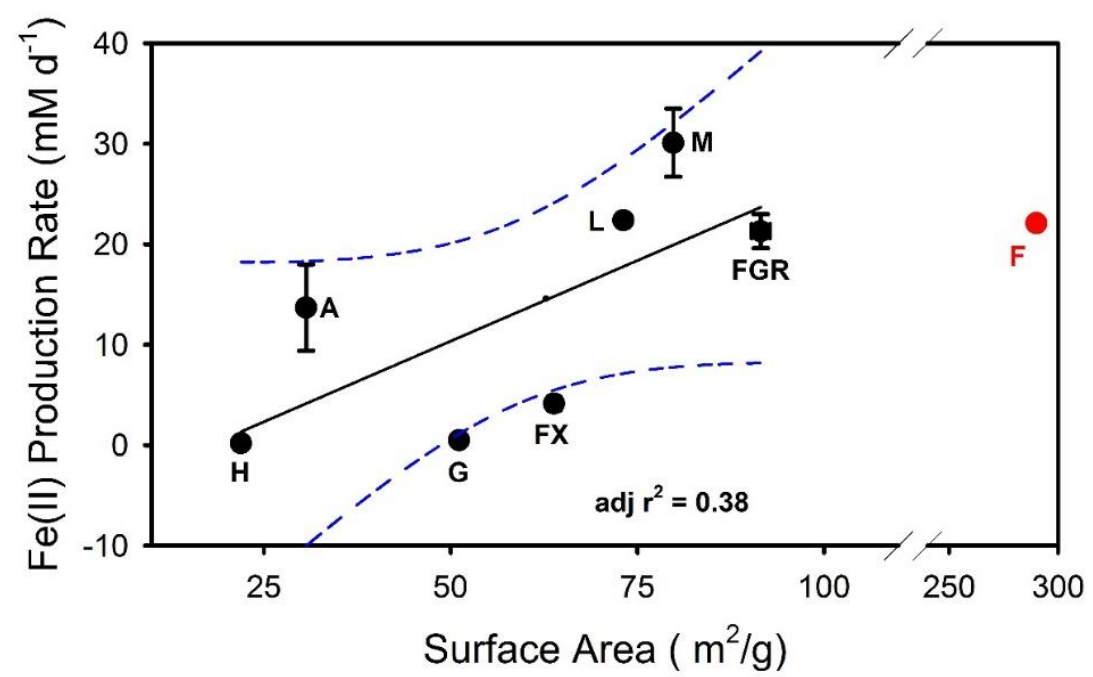

Figure 2. Relationship between Fe(II) production rate and Fe(III) oxide surface area. Ferrihydrite (F) was not included in the correlation. Dashed lines indicate $95 \%$ confidence intervals. $A=$ akaganeite, $\mathrm{FX}=$ feroxyhyte, $\mathrm{FGR}=$ ferric green rust, $\mathrm{G}=$ goethite, $\mathrm{H}=$ hematite, $\mathrm{L}=$ lepidocrocite, and $\mathrm{M}=$ maghemite.

\subsection{Hematite}

Within the first $24 \mathrm{~h}$ of incubation, $11 \mathrm{mM} \mathrm{Fe}(\mathrm{II})$ was produced from the bioreduction of hematite (Figure 3), followed by a more gradual increase in Fe(II) to $2.44 \mathrm{mM}$ by day 78. A final measurement was made 928 days after inoculation, at which point $6.9 \mathrm{mM}$ $\mathrm{Fe}(\mathrm{II})$ was produced, corresponding to a reduction of $8.6 \%$ of the hematite. The presence of the electron shuttle AQDS had essentially no effect on the rate of hematite bioreduction (Table 2); however, over time the extent of Fe(II) production in the AQDS-amended system was significantly greater. The presence of both AQDS and $500 \mu \mathrm{M}$ phosphate resulted in a significant increase in the initial rate of hematite bioreduction and higher levels of Fe(II) through the initial 74 days of the incubation, although by day 744 there was essentially no difference between either AQDS-amended system.
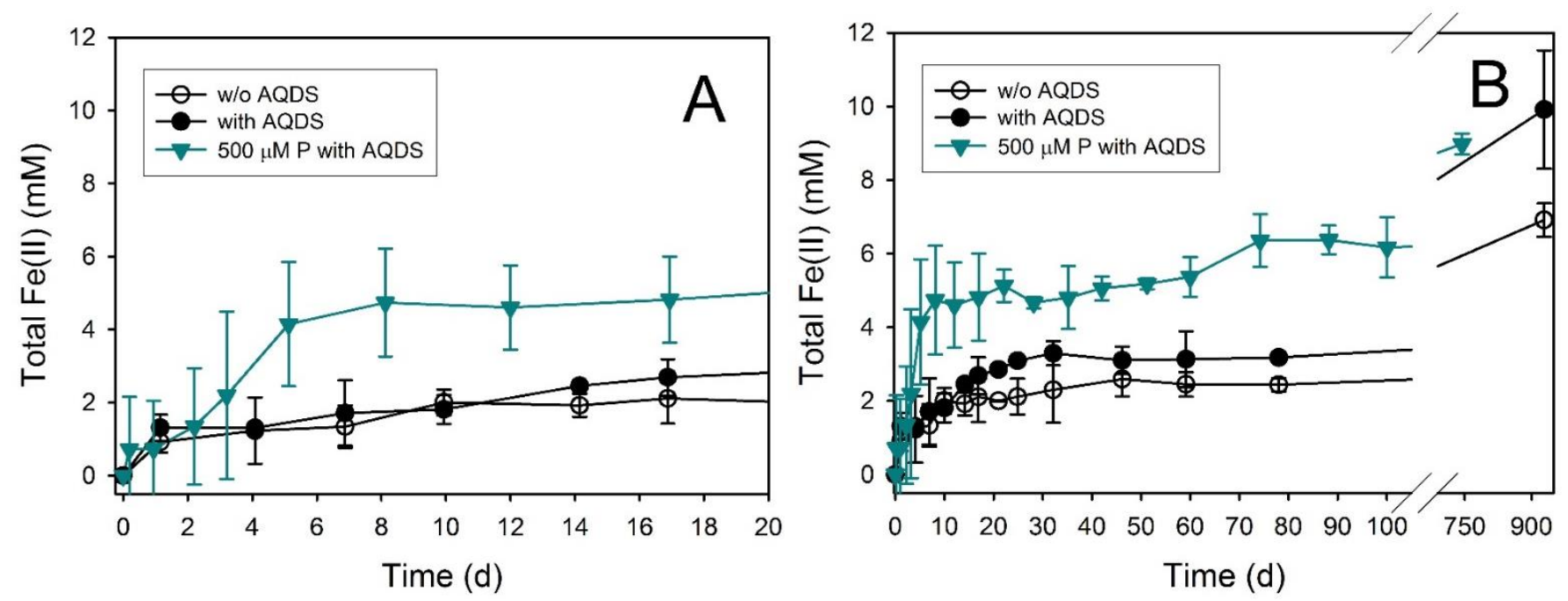

Figure 3. (A) Initial (<20 days) Fe(II) production during the bioreduction of hematite by S. putrefaciens CN32 and (B) over a period of up to 928 days. Error bars indicate one standard deviation. AQDS-9,10-anthraquinone-2,6-disulfonate; $\mathrm{P}$-phosphorous. 
Table 2. Maximum Fe(II) production rates, Fe(II) production, extent of Fe(III) reduction, and identification of secondary minerals.

\begin{tabular}{|c|c|c|c|c|c|c|c|}
\hline \multirow{2}{*}{ System } & \multirow{2}{*}{$\begin{array}{c}\mathrm{Fe}(\mathrm{II})_{\text {tot }} \text { Production } \\
\text { Rate }^{\mathrm{a}} \\
\left(\mathrm{mM} \cdot \mathrm{day}^{-1}\right)\end{array}$} & \multirow{2}{*}{$\begin{array}{c}\text { Final } \\
\text { Measurement } \\
\text { (day) }\end{array}$} & \multirow{2}{*}{$\begin{array}{l}\mathrm{Fe}(\mathrm{II})_{\text {tot }} \mathrm{b} \\
\quad(\mathrm{mM})\end{array}$} & \multirow{2}{*}{$\begin{array}{c}\text { Fe(III) } \\
\text { Reduced }^{b} \\
(\%)\end{array}$} & \multicolumn{3}{|c|}{ Identification of Secondary Minerals ${ }^{c}$} \\
\hline & & & & & XRD & Mössbauer & SEM \\
\hline Hematite & $0.17 \pm 0.08$ & 928 & $6.91 \pm 0.46$ & $8.6 \pm 0.6$ & Sid (trace) & ND & Sid (minor) \\
\hline Hematite + AQDS & $0.19 \pm 0.10$ & 928 & $9.91 \pm 1.61$ & $12.4 \pm 2.0$ & Sid (trace) & ND & Sid (minor) \\
\hline Hematite + AQDS + $500 \mu \mathrm{M} \mathrm{P}$ & $0.73 \pm 0.08$ & 744 & $8.98 \pm 0.28$ & $11.2 \pm 0.3$ & Sid (trace) & ND & Sid (minor) \\
\hline Goethite & $0.60 \pm 0.09$ & 1060 & $21.93 \pm 3.04$ & $27.4 \pm 3.8$ & inconclusive & Chuk & Chuk \\
\hline Goethite + AQDS & $1.05 \pm 0.28$ & 1060 & $32.21 \pm 1.60$ & $40.3 \pm 2.0$ & inconclusive & Chuk & Chuk \\
\hline Goethite + AQDS + 500 $\mu \mathrm{M} \mathrm{P}$ & $1.07 \pm 0.18$ & 744 & $3.20 \pm 0.89$ & $4.0 \pm 1.1$ & inconclusive & ND & Chuk \\
\hline Maghemite & $30.1 \pm 3.4$ & 184 & $58.84 \pm 1.66$ & $73.6 \pm 2.1$ & Mag, Chuk & Mag, Chuk & Mag, Chuk \\
\hline Maghemite + AQDS & $124.3 \pm 12.5$ & 184 & $56.20 \pm 1.43$ & $70.3 \pm 1.8$ & Mag, Chuk & Mag, Chuk & Mag, Chuk \\
\hline Maghemite + AQDS + $10 \mu \mathrm{M} \mathrm{P}$ & $137.8 \pm 11.6$ & 184 & $56.92 \pm 1.03$ & $71.2 \pm 1.3$ & Mag, Chuk & ND & Mag, Chuk \\
\hline Maghemite + AQDS + $100 \mu \mathrm{MP}$ & $141.8 \pm 7.2$ & 184 & $59.60 \pm 2.34$ & $74.5 \pm 2.9$ & Mag, Chuk & ND & Mag, Chuk \\
\hline Maghemite + AODS + 1 mM P & $114.6 \pm 1.1$ & 184 & $60.35 \pm 2.26$ & $75.4 \pm 2.8$ & Mag, Chuk & Mag, Chuk & Mag, Chuk \\
\hline Maghemite + AQDS + 10 mM P & $108.1 \pm 11.2$ & 184 & $39.66 \pm 2.73$ & $49.6 \pm 3.4$ & Mag, Viv & Mag, Viv & Mag, Viv \\
\hline Ferrihydrite & $62.2 \pm 5.8$ & 46 & $29.20 \pm 2.10$ & $36.5 \pm 2.6$ & Mag, Chuk & ND & Mag, Chuk \\
\hline Ferrihydrite + AQDS & $110.6 \pm 3.6$ & 46 & $44.30 \pm 1.02$ & $55.4 \pm 1.3$ & Mag, Chuk & Mag, Chuk & Mag, Chuk \\
\hline Ferrihydrite + AQDS + $10 \mu \mathrm{M} \mathrm{P}$ & $111.2 \pm 3.8$ & 46 & $39.78 \pm 4.86$ & $49.7 \pm 6.1$ & Mag, Chuk & ND & Mag, Chuk \\
\hline Ferrihydrite + AQDS + $100 \mu \mathrm{M} \mathrm{P}$ & $114.8 \pm 6.0$ & 46 & $40.60 \pm 3.42$ & $50.8 \pm 4.3$ & Mag, Chuk & ND & Mag, Chuk \\
\hline Ferrihydrite + AQDS + $1 \mathrm{mM} \mathrm{P}$ & $73.0 \pm 7.8$ & 46 & $40.80 \pm 0.06$ & $51.0 \pm 0.1$ & Mag, Chuk & Mag, Chuk & Mag, Chuk \\
\hline Ferrihydrite + AQDS + 10 mM P & $71.8 \pm 3.4$ & 46 & $61.46 \pm 2.46$ & $76.8 \pm 3.1$ & GR, Viv & GR, Viv & GR, Viv \\
\hline
\end{tabular}

${ }^{a} \mathrm{Fe}(\mathrm{II})$ production rates were calculated by linear regression using least-squares regression during the period of maximum sustained $\mathrm{Fe}(\mathrm{II})$ production. ${ }^{\mathrm{b}}$ At the time of the final measurement. ${ }^{\mathrm{c}}$ Siderite (Sid); Not determined (ND); Chukanovite (Chuk); Magnetite (Mag); Vivianite (Viv); and Green rust (GR).

Analysis of the solids in the hematite bioreactors by pXRD initially showed no evidence of crystalline secondary minerals (Figure 4). Following long-term incubation, indications of siderite are evident in all the treatments. Small, imperfect rhombohedral (pseudocubic) crystals were observed in the solids (Figure 5). The crystals were 200-500 nm on the edge and were dispersed as single crystals in a hematite groundmass. The overall morphology of these crystals is similar to that of siderite formed during the bioreduction of $\mathrm{Fe}(\mathrm{III})$ oxides $[17,92-94]$. Previous studies of the bioreduction of hematite have reported the formation of magnetite and vivianite as secondary minerals [22,95,96]; however, there was no indication that either of these phases formed in any of our hematite bioreduction systems.

\subsection{Goethite}

Within the first seven days after inoculation, the rate of $\mathrm{Fe}(\mathrm{II})$ production during goethite bioreduction was $0.60 \pm 0.09 \mu \mathrm{M} \cdot \mathrm{day}^{-1}$, after which the rate decreased considerably (Figure 6). The presence of AQDS increased the initial rate of Fe(II) production to $1.05 \pm 0.28 \mu \mathrm{M} \cdot \mathrm{day}^{-1}$, and throughout the experiment, the amount of Fe(II) was greater compared to the unamended system (Figure 6 and Table 2). The addition of $500 \mu \mathrm{M}$ phosphate had no effect on the initial rate of Fe(II) production; however, after day 8, the Fe(II) levels remained essentially unchanged.

Although siderite and vivianite have been observed as secondary minerals, resulting from the bioreduction of goethite $[84,93,97,98]$, analysis of the solids in the goethite bioreactors by pXRD provided no conclusive evidence of crystalline secondary minerals (Figure 7). However, there is a small peak at $\sim 34^{\circ} 2 \theta$ in the diffraction pattern of the solids from both the unamended and AQDS-amended bioreactors at 1060 days. This peak corresponds to a prominent chukanovite peak in the diffraction patterns of secondary minerals, formed during the bioreduction of akaganeite, lepidocrocite, and maghemite by S. putrefaciens $\mathrm{CN} 32$ under conditions similar to those in the goethite bioreactors in this study $[31,66,67] .{ }^{57} \mathrm{Fe}$ Mössbauer analysis of the solids in both systems indicated $22 \%$ chukanovite (Table 3). In addition, SEM imaging of the solids in bioreactors with and without AQDS amendment show platy crystallites with a morphology consistent with that of biogenic chukanovite [21,41,66], among residual goethite crystals (Figure 8B,C). There was no evidence of secondary mineral formation in the goethite bioreactors amended with both AQDS and phosphate; however, the goethite did become more crystalline (Figure 7), and goethite crystallite morphology changed from acicular to lath-like (Figure 8A,D). 

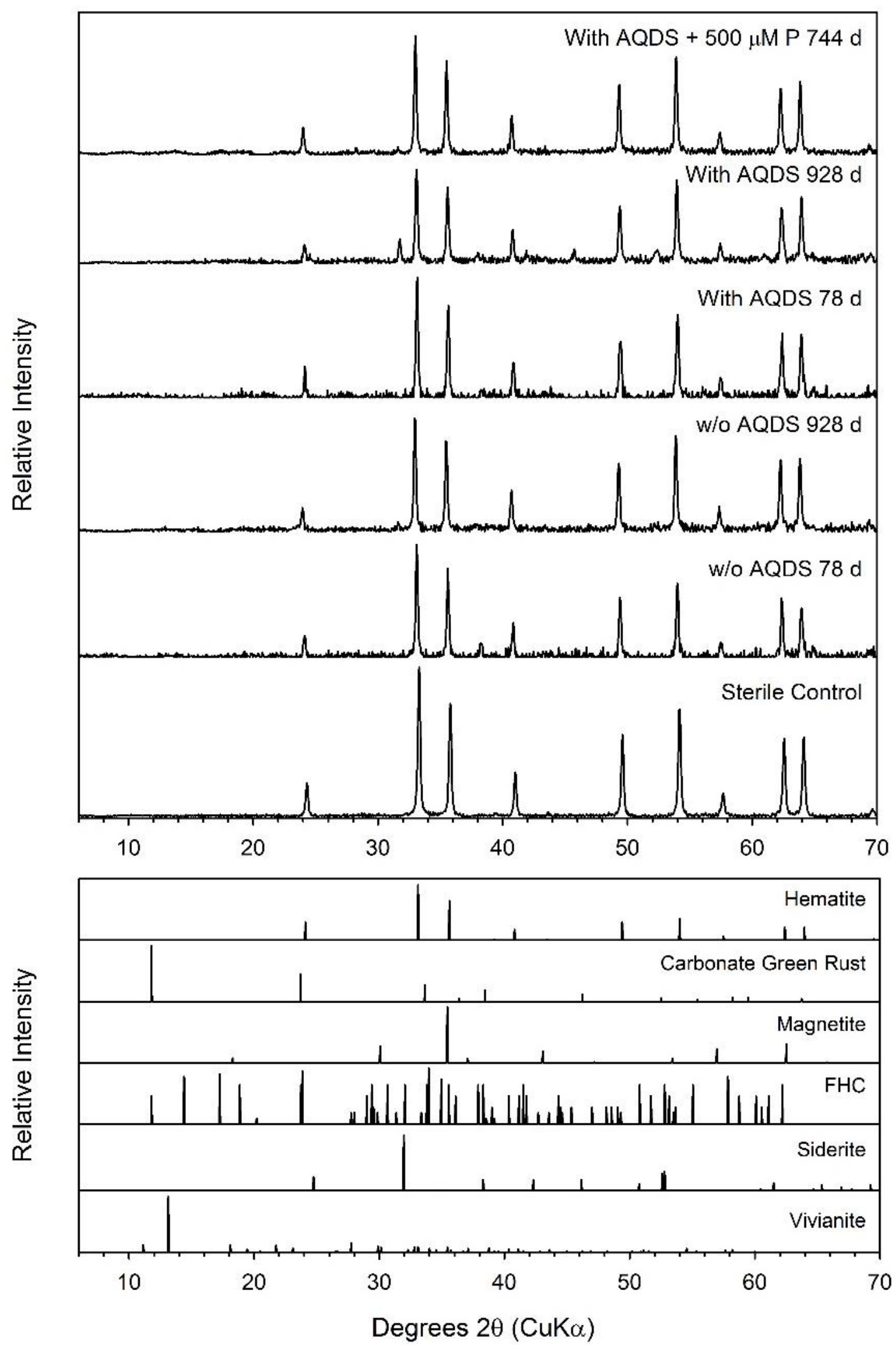

Figure 4. pXRD analysis of the solids in the hematite bioreduction systems at the end of the incubations. FHC is ferrous hydroxy carbonate (chukanovite). 

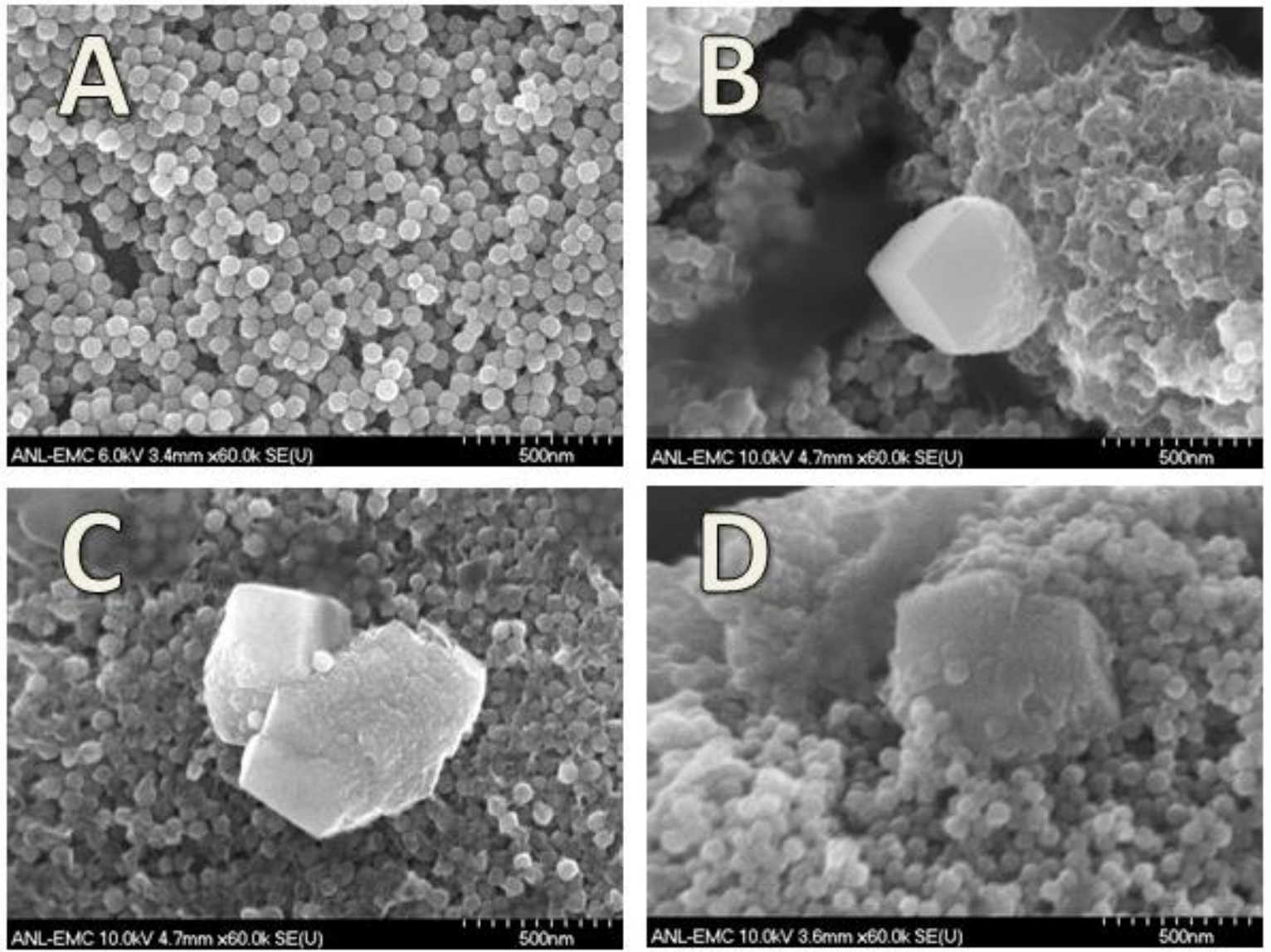

Figure 5. SEM images of the hematite used in this study (A) and the solids at the end of the incubations in the hematite bioreduction systems in the absence (B) and presence of AQDS (C) and AQDS with $500 \mu \mathrm{M}$ phosphate (D).
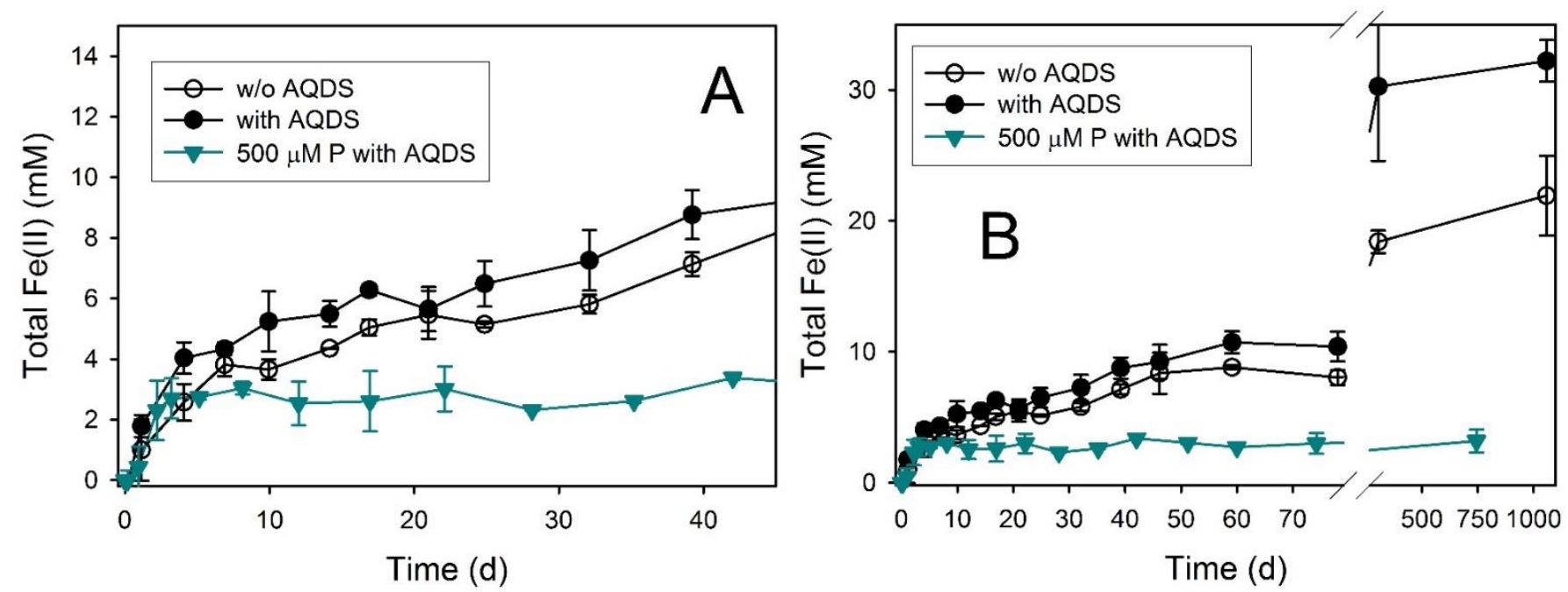

Figure 6. (A) Initial (<45 days) Fe(II) production during the bioreduction of goethite by S. putrefaciens CN32 and (B) over a period of up to 1060 days. Error bars indicate one standard deviation. 

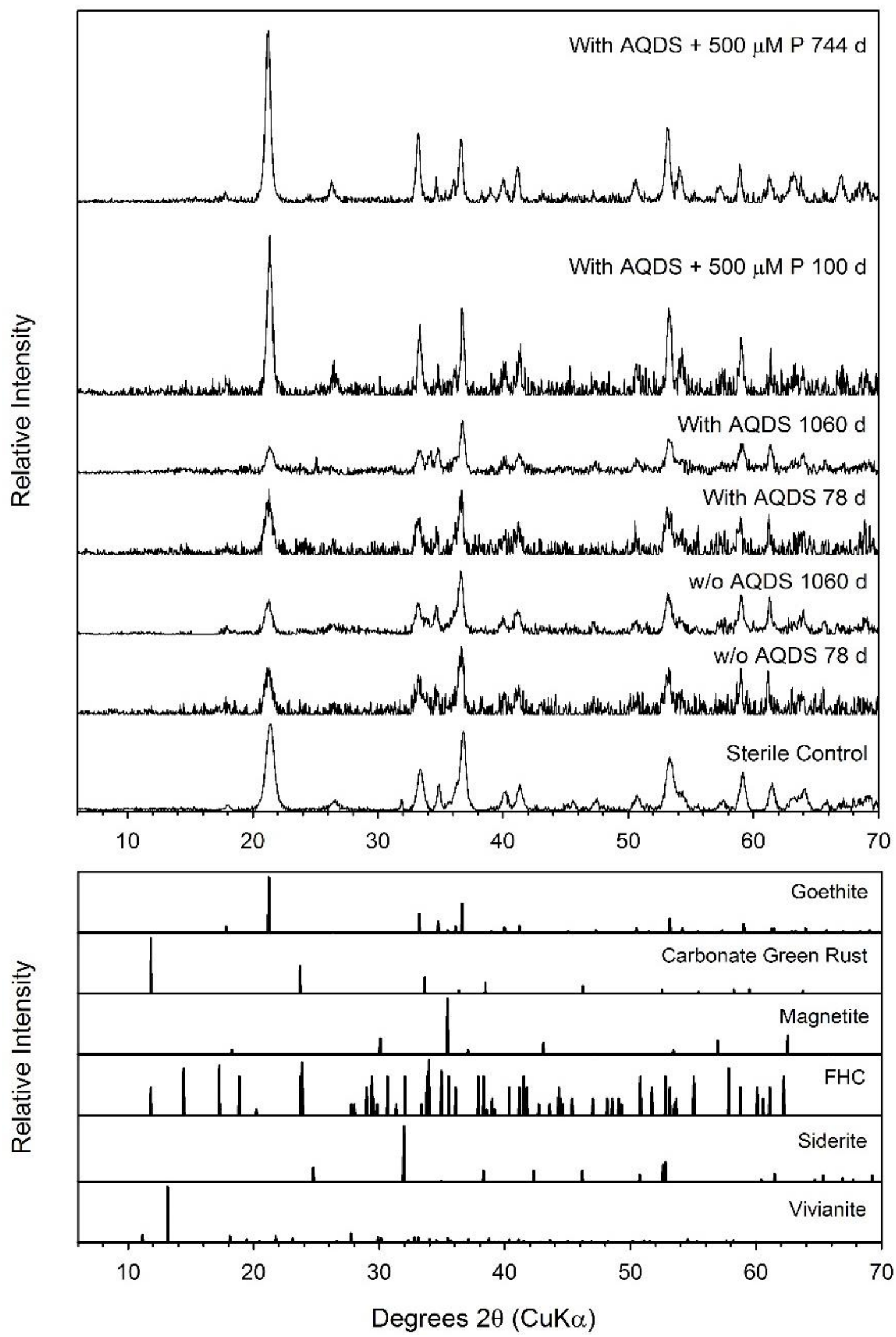

Figure 7. pXRD analysis of the solids in the goethite bioreduction systems at the end of the incubations. FHC is ferrous hydroxy carbonate (chukanovite). 

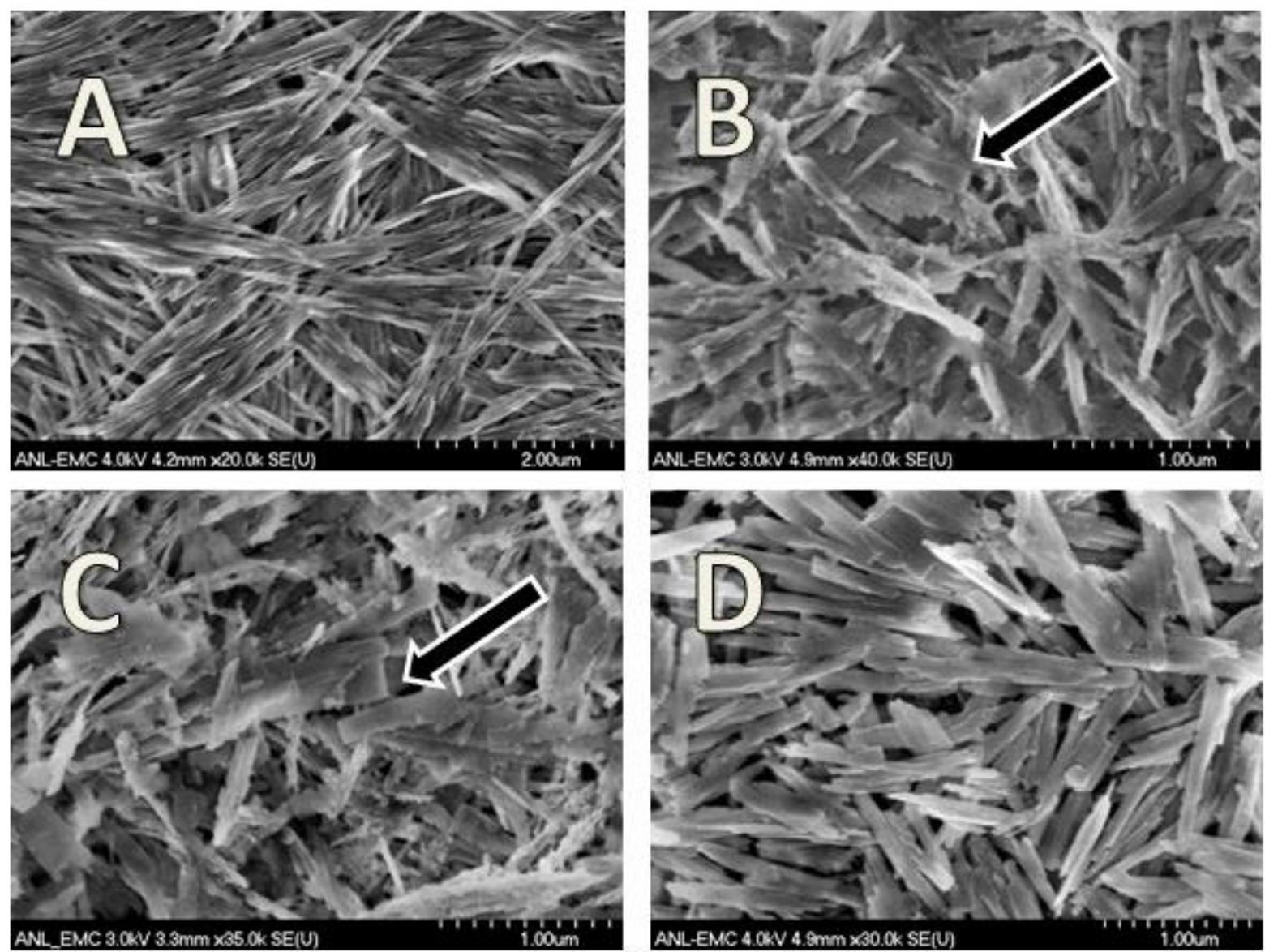

Figure 8. SEM images of the goethite used in this study (A) and the solids at the end of the incubations in the goethite bioreduction systems in the absence (B) and presence of AQDS (C) and AQDS with 500. $\mu \mathrm{M}$ phosphate (D). The arrow in panel $\mathrm{C}$ is pointing to bladed chukanovite crystallites.

Table 3. Fit parameters from Mössbauer analysis of the secondary minerals in the indicated systems.

\begin{tabular}{|c|c|c|c|c|c|c|}
\hline \multirow{2}{*}{ Sample } & Temp & $\mathrm{CS}$ & QS & $\mathrm{H}$ & & RA \\
\hline & (K) & $\left(\mathrm{mm} \cdot \mathrm{s}^{-1}\right)$ & $\left(\mathrm{mm} \cdot \mathrm{s}^{-1}\right)$ & (T) & Mineral & $(\%)$ \\
\hline \multirow[b]{2}{*}{ Goethite } & 140 & 0.46 & -0.12 & 47.9 & Goethite & 80.0 \\
\hline & & 1.25 & 2.28 & & Chukanovite & 20.0 \\
\hline \multirow{6}{*}{ Goethite + AQDS } & 270 & 0.39 & -0.13 & 39.2 & Goethite & 78.4 \\
\hline & & 1.16 & 2.03 & & Chukanovite & 21.6 \\
\hline & 140 & 0.46 & -0.12 & 47.9 & Goethite & 72.6 \\
\hline & & 1.25 & 2.27 & & Chukanovite & 27.4 \\
\hline & 77 & 0.48 & -0.12 & 49.8 & Goethite & 71.0 \\
\hline & & 1.27 & 2.37 & & Chukanovite & 29.0 \\
\hline \multirow{3}{*}{ Maghemite } & 140 & 1.26 & 2.21 & & Chukanovite & 45.7 \\
\hline & & 0.72 & -0.04 & 46.8 & Magnetite (oct 2.5) & 34.8 \\
\hline & & 0.38 & 0.00 & 49.7 & Magnetite (tet 3) & 19.5 \\
\hline \multirow{3}{*}{ Maghemite + AQDS } & 140 & 1.26 & 2.21 & & Chukanovite & 40.8 \\
\hline & & 0.72 & -0.04 & 46.4 & Magnetite (oct 2.5) & 38.9 \\
\hline & & 0.38 & 0.00 & 49.6 & Magnetite (tet 3) & 20.4 \\
\hline \multirow{3}{*}{ Maghemite + AQDS + 1 mM P } & 140 & 1.26 & 2.26 & & Chukanovite & 41.0 \\
\hline & & 0.73 & -0.05 & 46.0 & Magnetite (oct 2.5) & 37.0 \\
\hline & & 0.38 & 0.00 & 49.3 & Magnetite (tet 3) & 22.1 \\
\hline
\end{tabular}


Table 3. Cont.

\begin{tabular}{|c|c|c|c|c|c|c|}
\hline \multirow{2}{*}{ Sample } & Temp & CS & QS & $\mathbf{H}$ & & RA \\
\hline & $(\mathrm{K})$ & $\left(\mathrm{mm} \cdot \mathrm{s}^{-1}\right)$ & $\left(\mathrm{mm} \cdot \mathrm{s}^{-1}\right)$ & $(\mathrm{T})$ & Mineral & $(\%)$ \\
\hline \multirow{3}{*}{ Maghemite + AQDS + 10 mM P } & 140 & 1.28 & 3.00 & & Vivianite & 18.2 \\
\hline & & 0.72 & 0.04 & 45.4 & Magnetite (oct 2.5) & 47.7 \\
\hline & & 0.40 & -0.05 & 49.9 & Magnetite (tet 3) & 34.1 \\
\hline \multirow{3}{*}{ Ferrihydrite } & 77 & 1.28 & 2.29 & & Chukanovite & 60.9 \\
\hline & & 0.39 & -0.01 & 49.9 & Magnetite 1 & 17.1 \\
\hline & & 0.79 & -0.09 & 47.3 & Magnetite 2 & 22.0 \\
\hline \multirow{6}{*}{ Ferrihydrite + AQDS + 1 mM P } & 140 & 1.26 & 2.40 & & Chukanovite & 56.0 \\
\hline & & 0.72 & -0.03 & 46.4 & Magnetite (oct 2.5) & 29.4 \\
\hline & & 0.38 & -0.02 & 49.5 & Magnetite (tet 3) & 14.5 \\
\hline & 77 & 1.29 & 2.48 & & Chukanovite & 47.7 \\
\hline & & 0.38 & 0.02 & 50.0 & Magnetite 1 & 15.1 \\
\hline & & 0.80 & -0.13 & 46.8 & Magnetite 2 & 37.2 \\
\hline \multirow{6}{*}{ Ferrihydrite + AQDS + $10 \mathrm{mM} \mathrm{P}$} & 77 & 0.46 & 0.40 & & Green Rust Fe(III) & 17.0 \\
\hline & & 1.19 & 2.87 & & Green Rust Fe(II) & 40.8 \\
\hline & & 1.39 & 2.98 & & Vivianite & 42.2 \\
\hline & 13 & 0.48 & 0.38 & & Green Rust Fe(III) & 19.2 \\
\hline & & 1.26 & 2.84 & & Green Rust Fe(II) & 65.5 \\
\hline & & 1.47 & 3.04 & & Vivianite & 15.3 \\
\hline
\end{tabular}

\subsection{Maghemite}

Maghemite was readily reduced by CN32 (Figure 9) with an initial rate of Fe(II) production of $\sim 30 \mathrm{mM} \cdot$ day $^{-1}$. The presence of AQDS resulted in a 4-fold increase in the initial rate of $\mathrm{Fe}(\mathrm{II})$ production, but over time the overall extent of $\mathrm{Fe}(\mathrm{III})$ reduction was the same as the non-AQDS-amended system (Table 2). The pXRD patterns of the solids in the AQDS- and AQDS+ systems at the end of the incubation were similar, with both showing remnant maghemite peaks, as well as peaks corresponding to chukanovite (Figure 10). Likewise, ${ }^{57} \mathrm{Fe}$ Mössbauer analysis of the solids in both systems showed similar levels of chukanovite and magnetite (Table 3). Maghemite is isostructural with magnetite and is the fully oxidized end member of a solid solution with stoichiometric magnetite as the fully reduced end member. As such, maghemite can be reduced to magnetite via topotactic transformation. The transformation from maghemite to magnetite is apparent in the Mössbauer spectra, due to the appearance of an octahedral $\mathrm{Fe}^{2.5+}$ signal, which has a center shift $(\sim 0.72 \mathrm{~mm} / \mathrm{s})$ that differs from the center shift for octahedral $\mathrm{Fe}^{3+}$ and tetrahedral $\mathrm{Fe}^{3+}(\sim 0.38 \mathrm{~mm} / \mathrm{s})$. The octahedral $\mathrm{Fe}^{2.5+}$ mixed valence signal is a consequence of electron hopping, occurring between octahedral sites at a rate substantially faster than the characteristic time of Mössbauer spectroscopy [99]. Although the magnetite largely retains the morphology of the parent maghemite crystallites, the edges are more irregular and there is significant pitting (Figure 11A,B). Bladed chukanovite crystallites are evident in both AQDS- and AQDS+ systems (Figure 11C,D).

The effect of phosphate concentration $(0-10 \mathrm{mM})$ on maghemite bioreduction was observed in AQDS-amended systems. Phosphate concentration had essentially no effect within the first $23 \mathrm{~h}$ of incubation (Figure 9A). Fe(II) levels in the $10 \mathrm{mM}$ phosphate system were higher from day 1.5 through day 3 than those in the systems with $1 \mathrm{mM}$ phosphate or less; however, from day 31 through to the end of the incubation, the Fe(II) concentration in the $10 \mathrm{mM}$ phosphate system was significantly lower ( $\sim 40 \mathrm{mM}$ versus $55-60$ at day 184 ). Chukanovite and magnetite were identified as secondary minerals in the $0,0.01,0.1$, and $1 \mathrm{mM}$ phosphate systems; however, the $10 \mathrm{mM}$ phosphate system contained vivianite and magnetite (Table 3, and Figures 10 and 11); the formation of magnetite in the 0.01 and $0.1 \mathrm{mM}$ phosphate systems was not directly observed but inferred from the Mössbauer analysis of the 0,1 , and $10 \mathrm{mM}$ phosphate systems (Table 3 ). 

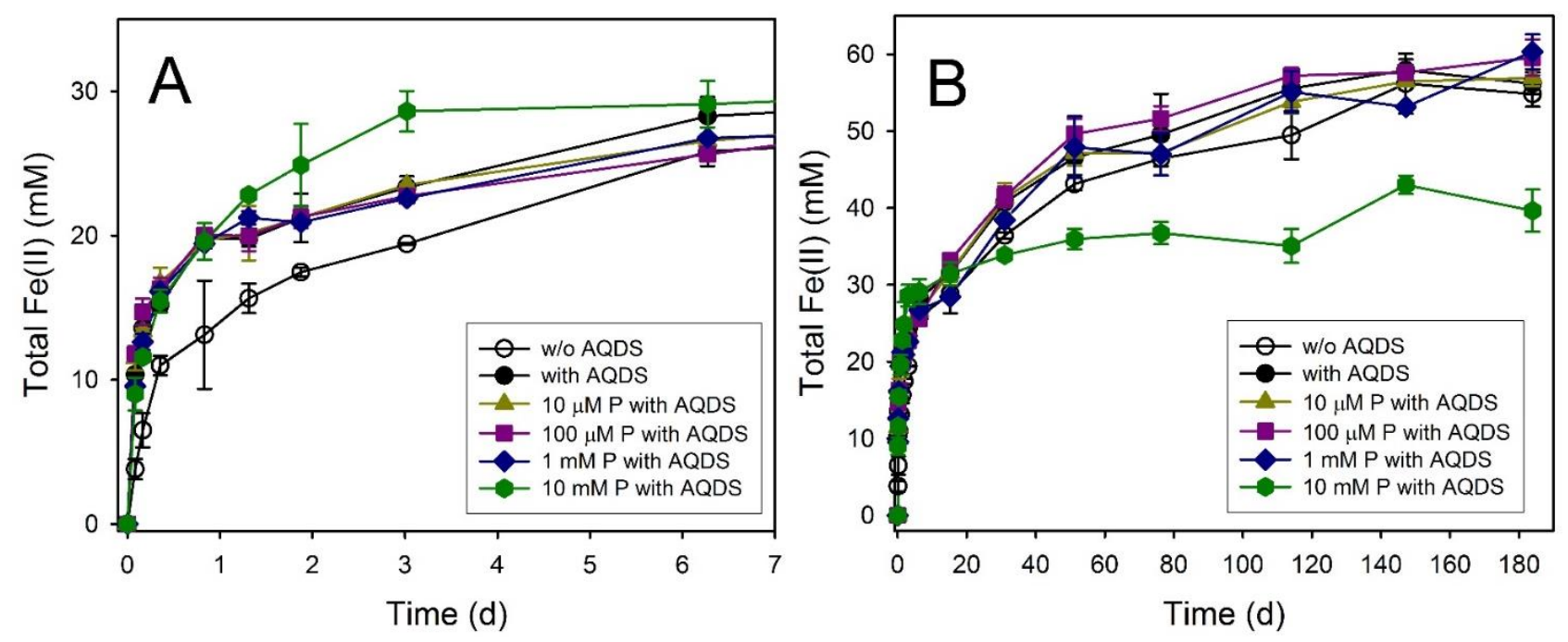

Figure 9. (A) Initial (<7 days) Fe(II) production during the bioreduction of maghemite by S. putrefaciens CN32 and (B) over a period of 184 days. Error bars indicate one standard deviation.

\subsection{Ferrihydrite}

The bioreduction of ferrihydrite produced $\sim 27 \mathrm{mM}$ Fe(II) within $24 \mathrm{~h}$, after which the $\mathrm{Fe}(\mathrm{II})$ concentrations remained essentially stable until the end of the incubation (Figure 12). Analysis of the solids by pXRD 46 days after inoculation indicated the presence of magnetite and FHC (Figure 13). The magnetite was in the form of aggregated, nominally cubic crystallites $\sim 10 \mathrm{~nm}$ (Figure 14A), consistent with the nano-scale magnetite commonly observed as a secondary mineral of ferrihydrite bioreduction $[17,29,100]$. Irregular, bladed chukanovite crystals were dispersed among the magnetite groundmass (Figure 14B). The initial rate of $\mathrm{Fe}(\mathrm{II})$ production was nearly double in the presence of AQDS (Table 2) and the overall extent of $\mathrm{Fe}(\mathrm{II})$ production at the end of the incubation was substantially greater than in the absence of AQDS ( $44 \mathrm{mM}$ versus $29 \mathrm{mM}$ ). Ferrihydrite was transformed to magnetite and chukanovite (Figures 13 and 14C), with chukanovite as the dominant secondary mineral (Table 2). Although the initial rate of Fe(II) production was lower in the presence of $1 \mathrm{mM}$ phosphate, overall, phosphate concentrations from $0.01-1 \mathrm{mM}$ had little effect on the extent of ferrihydrite bioreduction (Figure 12). Magnetite and chukanovite were observed as secondary minerals over this range of phosphate concentrations; however, the phases became less crystalline with increasing phosphate concentration (Figure 13) and the chukanovite crystallites became increasingly irregular (Figure 14D-F). The addition of $10 \mathrm{mM}$ phosphate resulted in a biphasic $\mathrm{Fe}(\mathrm{II})$ production profile. After the initial $6 \mathrm{~h}$ period of rapid Fe(II) production $\left(71.8 \pm 3.4 \mathrm{mM} \cdot\right.$ day $\left.^{-1}\right)$, a rate of $1.58 \pm 0.05 \mathrm{mM} \cdot$ day $^{-1}$ was sustained from day 1 through 23 , resulting in the accumulation of $\sim 60 \mathrm{mM} \mathrm{Fe}(\mathrm{II})$. At this phosphate concentration, green rust and vivianite formed as secondary minerals (Figure 13 and Table 2); magnetite and chukanovite were not evident. The green rust crystallites were platy and nominally hexagonal (Figure 14G,H) but did not have the well-defined edges often reported for biogenic green rust $[17,18,66,101]$. The vivianite was present as tabular crystallites up to $25 \mu \mathrm{m}$ in the longest dimension and occasionally as twins (Figure 14G,H), consistent with previous reports of biogenic vivianite resulting from the bioreduction of ferrihydrite $[19,66,92,94,102]$. 

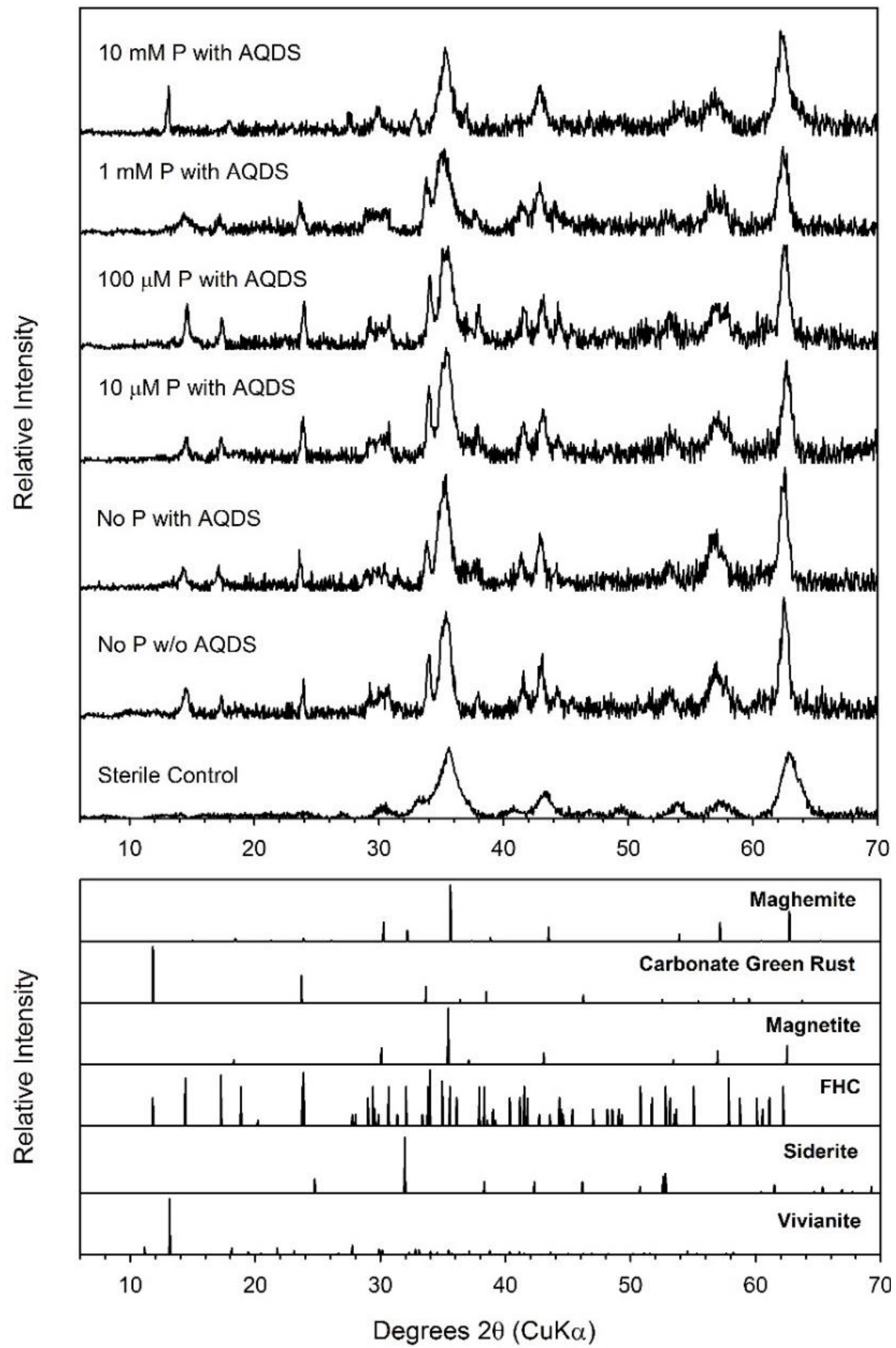

Figure 10. pXRD analysis of the solids in the maghemite bioreduction systems at the end of the incubations (184 days). FHC is ferrous hydroxy carbonate (chukanovite). 

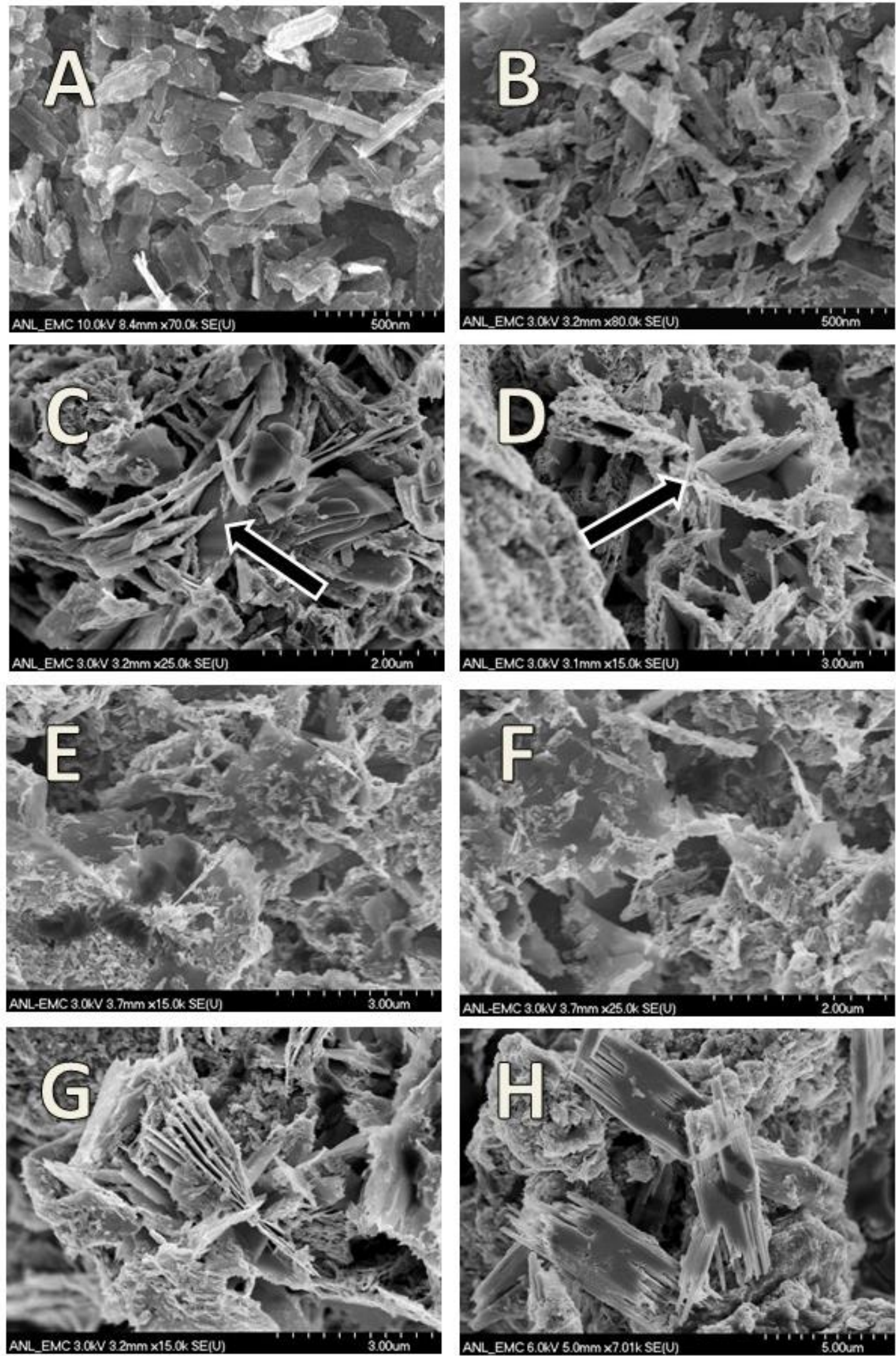

Figure 11. SEM images of the maghemite used in this study (A) and the solids at the end of the incubation (184 days) in the maghemite bioreduction systems with no added phosphate in the absence of AQDS $(\mathbf{B}, \mathbf{C})$ and the presence of AQDS with no added phosphate (D), $10 \mu \mathrm{M}$ phosphate (E), $100 \mu \mathrm{M}$ phosphate (F), $1 \mathrm{mM}$ phosphate (G), and $10 \mathrm{mM}$ phosphate (H). The arrows in panel $\mathrm{C}$ and $\mathrm{D}$ are pointing to bladed chukanovite crystallites. 

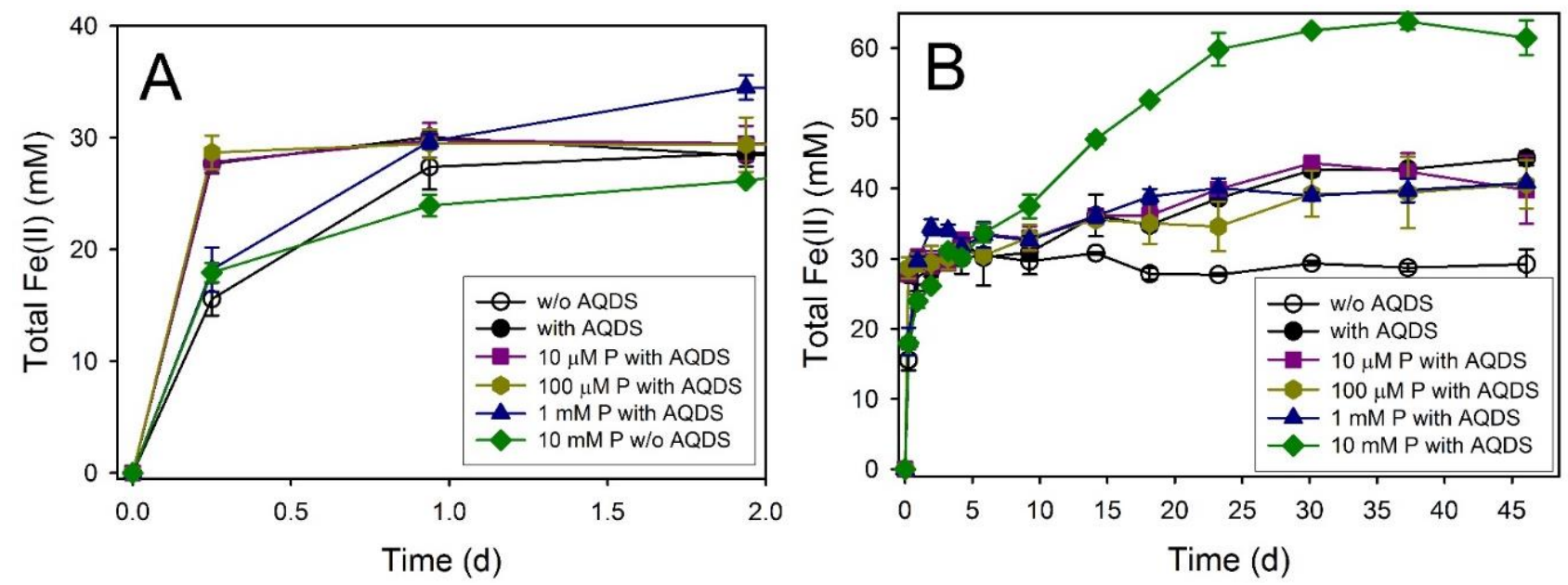

Figure 12. (A) Initial (<2 days) Fe(II) production during the bioreduction of ferrihydrite by S. putrefaciens CN32 and (B) over a period of 46 days. Error bars indicate one standard deviation.

\subsection{Lepidocrocite}

The presence of AQDS significantly enhanced the rate of Fe(II) production during lepidocrocite bioreduction, but resulted in only a minor increase in the overall extent of $\mathrm{Fe}(\mathrm{II})$ production (Figure 15 and Table 4 ): $~ 80 \%$ of Fe(II) production occurred within 0.9 days in the presence of AQDS but it took 4.8 days to achieve the same extent in the absence of AQDS. pXRD analysis of the solids remaining in both systems at the end of the incubation showed the formation of magnetite and no indication of residual lepidocrocite (Figure 16); however, SEM imaging of the solids showed both fine-grained magnetite $(\sim 50 \mathrm{~nm})$ and bladed micron-sized chukanovite crystallites (Figure 17B-D). Magnetite and chukanovite are commonly reported products of the microbial reduction of lepidocrocite $[18,26,27,31,41,66,103]$, but there were no indications of less commonly observed secondary minerals, such as siderite or goethite [97].

Table 4. Maximum Fe(II) production rates, Fe(II) production, extent of Fe(III) reduction, and identification of secondary minerals.

\begin{tabular}{|c|c|c|c|c|c|c|c|}
\hline \multirow[t]{2}{*}{ System } & \multirow{2}{*}{$\begin{array}{c}\text { Fe(II) })_{\text {tot }} \text { Production } \\
\text { Rate }^{\mathrm{a}} \\
\left(\mathrm{mM} \cdot \text { day }^{-1}\right)\end{array}$} & \multirow{2}{*}{$\begin{array}{c}\text { Final } \\
\text { Measurement } \\
\text { (day) }\end{array}$} & \multirow{2}{*}{$\begin{array}{c}\mathrm{Fe}(\mathrm{II})_{\text {tot }} \mathrm{b} \\
(\mathrm{mM})\end{array}$} & \multirow{2}{*}{$\begin{array}{c}\text { Fe(III) } \\
\text { Reduced }^{b} \\
(\%)\end{array}$} & \multicolumn{3}{|c|}{ Identification of Secondary Minerals ${ }^{c}$} \\
\hline & & & & & XRD & Mössbauer & SEM \\
\hline Lepidocrocite & $12.7 \pm 1.9$ & 77 & $27.63 \pm 1.01$ & $34.5 \pm 1.3$ & Mag, Chuk & ND & Mag, Chuk \\
\hline Lepidocrocite + AQDS & $25.9 \pm 6.9$ & 77 & $31.95 \pm 0.40$ & $39.9 \pm 0.5$ & Mag, Chuk & ND & Mag, Chuk \\
\hline Lepidocrocite + AQDS + $1 \mu \mathrm{M} \mathrm{P}$ & $28.6 \pm 3.2$ & 77 & $30.18 \pm 0.86$ & $37.7 \pm 1.1$ & Mag, Chuk & ND & Mag, Chuk \\
\hline Lepidocrocite + AQDS + $10 \mu \mathrm{M} \mathrm{P}$ & $29.9 \pm 1.8$ & 77 & $31.06 \pm 0.81$ & $38.8 \pm 1.0$ & Mag, Chuk & ND & Mag, Chuk \\
\hline Lepidocrocite + AQDS + $25 \mu \mathrm{M} \mathrm{P}$ & $29.2 \pm 1.4$ & 50 & $30.69 \pm 2.05$ & $38.4 \pm 2.6$ & Mag, Chuk & ND & Mag, Chuk \\
\hline Lepidocrocite + AQDS + $50 \mu \mathrm{MP}$ & $12.6 \pm 4.2$ & 50 & $33.00 \pm 2.15$ & $41.3 \pm 2.7$ & Mag, Chuk & ND & Mag, Chuk \\
\hline Lepidocrocite + AQDS + $75 \mu \mathrm{M}$ P Rep 1 & $9.8 \pm 2.7$ & 50 & 37.16 & 46.5 & Mag, Chuk & ND & Mag, Chuk \\
\hline Lepidocrocite + AQ̄DS + $75 \mu \mathrm{M}$ P Rep 2 & $4.4 \pm 1.3$ & 50 & 54.75 & 68.4 & GR & ND & GR \\
\hline Lepidocrocite + AQDS + $100 \mu \mathrm{M} \mathrm{P}$ & $2.0 \pm 0.1$ & 77 & $55.19 \pm 1.19$ & $69.0 \pm 1.5$ & GR & ND & GR \\
\hline Lepidocrocite + AQDS + 1 mM P & $3.3 \pm 0.4$ & 77 & $60.04 \pm 0.07$ & $75.1 \pm 0.1$ & GR & ND & GR \\
\hline Lepidocrocite + AQDS + 10 mM P & $1.9 \pm 0.1$ & 77 & $71.36 \pm 4.30$ & $89.2 \pm 5.4$ & GR, Viv & ND & GR, Viv \\
\hline Feroxyhyte & $4.4 \pm 0.2$ & 78 & $24.28 \pm 2.10$ & $30.4 \pm 2.6$ & Mag, Chuk & ND & Mag, Chuk \\
\hline Feroxyhyte + AQDS & $23.3 \pm 3.2$ & 78 & $24.51 \pm 6.02$ & $30.6 \pm 7.5$ & Mag, Chuk & Mag, Chuk & Mag, Chuk \\
\hline Feroxyhyte + AQDS + $500 \mu \mathrm{M} \mathrm{P}$ & $0.6 \pm 0.01$ & 156 & $55.07 \pm 2.92$ & $68.8 \pm 3.7$ & Mag, Chuk & Mag, Chuk & Mag, Chuk \\
\hline Feroxyhyte + AQDS + 5 mM P & $0.7 \pm 0.03$ & 156 & $59.93 \pm 1.65$ & $74.9 \pm 2.1$ & GR, Viv & ND & GR?, Viv \\
\hline Ferric Green Rust & $18.9 \pm 0.1$ & 98 & $38.01 \pm 1.00$ & $47.5 \pm 3.3$ & Mag, Chuk & ND & Mag, Chuk \\
\hline Ferric Green Rust + AQDS & $91.3 \pm 5.3$ & 98 & $39.12 \pm 2.02$ & $48.9 \pm 1.6$ & Mag & Mag, Chuk & Mag, Chuk \\
\hline Ferric Green Rust + AQDS + $500 \mu \mathrm{M} P$ & $100.4 \pm 5.8$ & 98 & $36.07 \pm 2.10$ & $45.1 \pm 7.6$ & Mag, Chuk & Mag, Chuk & Mag, Chuk \\
\hline Ferric Green Rust + AQDS + 5 mM P & $1.1 \pm 0.1$ & 98 & $64.64 \pm 1.78$ & $80.8 \pm 5.4$ & GR & GR & GR \\
\hline
\end{tabular}

${ }^{a} \mathrm{Fe}(\mathrm{II})$ production rates were calculated by linear regression using least-squares regression during the period of maximum sustained Fe(II) production. ${ }^{\mathrm{b}}$ At the time of the final measurement. ${ }^{\mathrm{c}}$ Magnetite (Mag); Chukanovite (Chuk); Not determined (ND); Vivianite (Viv); and Green rust (GR). 


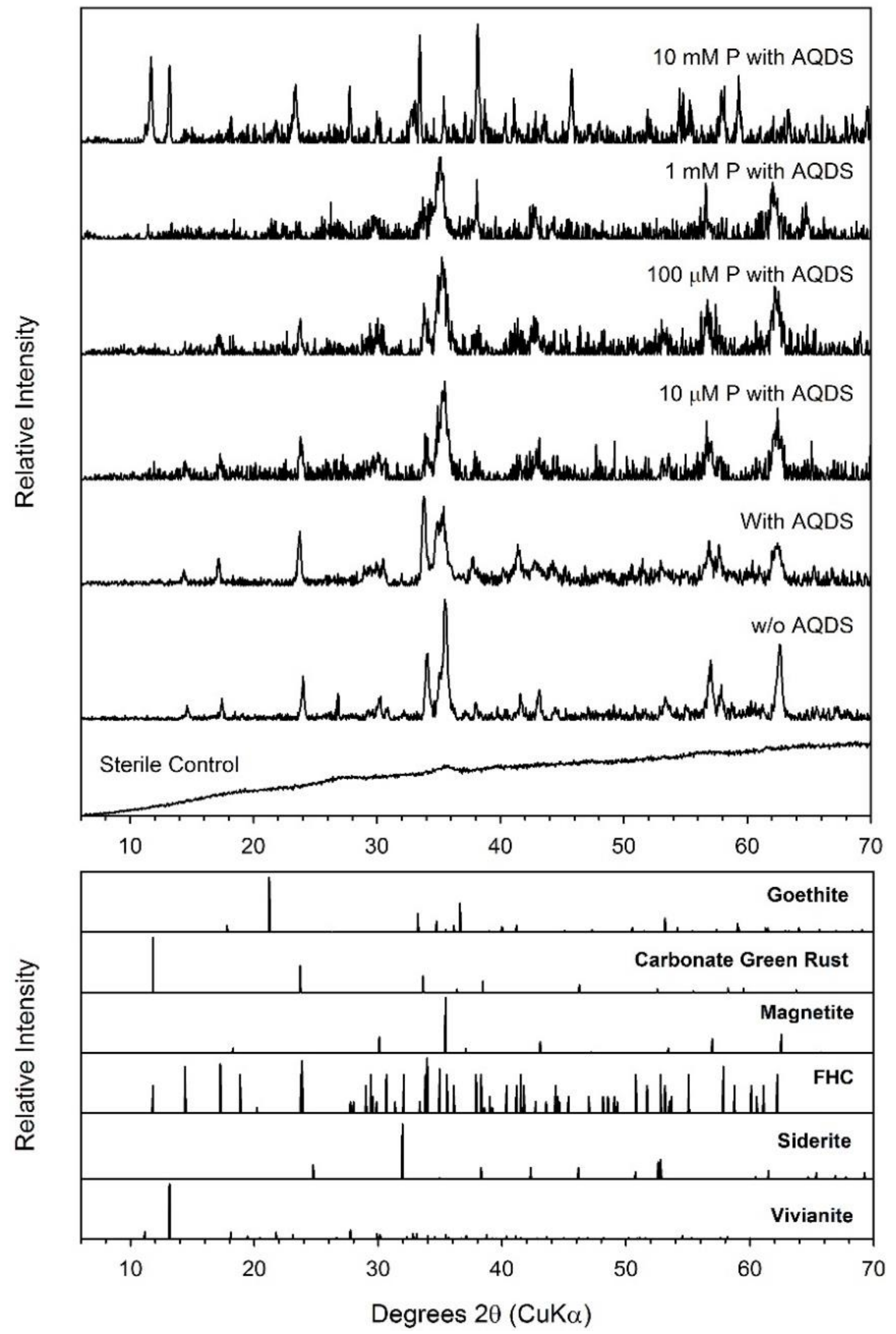

Figure 13. pXRD analysis of the solids in the ferrihydrite bioreduction systems at the end of the incubations (46 days). FHC is ferrous hydroxy carbonate (chukanovite). 

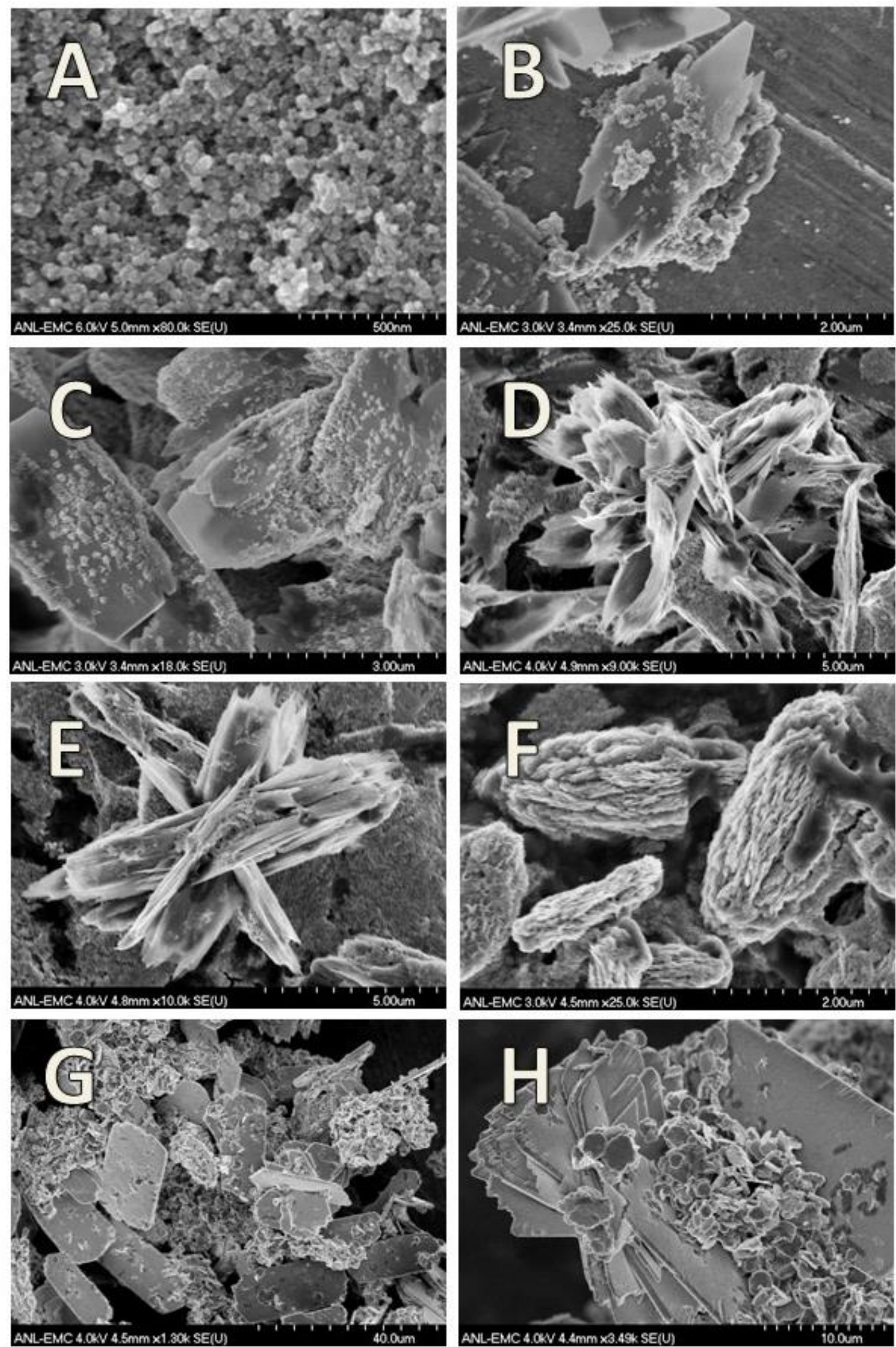

Figure 14. SEM images of the solids at the end of the incubation (46 days) in the ferrihydrite bioreduction systems with no added phosphate in the absence of AQDS $(\mathbf{A}, \mathbf{B})$ and in the presence of AQDS with no added phosphate $(\mathbf{C}), 10 \mu \mathrm{M}$ phosphate (D), $100 \mu \mathrm{M}$ phosphate (E), $1 \mathrm{mM}$ phosphate (F), and $10 \mathrm{mM}$ phosphate $(\mathbf{G}, \mathbf{H})$. 

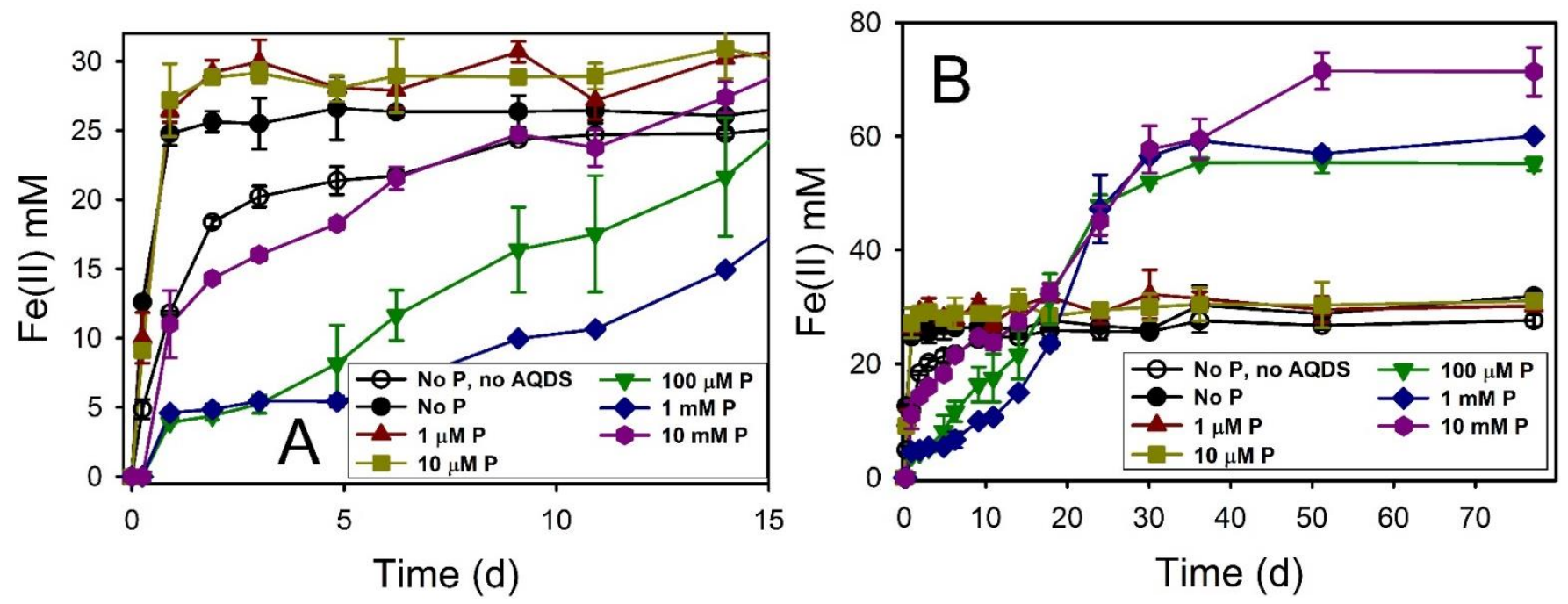

Figure 15. (A) Initial (<15 days) Fe(II) production during the bioreduction of lepidocrocite by S. putrefaciens CN32 and (B) over a period of 79 days. Error bars indicate one standard deviation. Unless otherwise indicated, all systems contained $100 \mu \mathrm{M}$ AQDS.

In a previous study, we observed that the presence of $500 \mu \mathrm{M}$ phosphate had a substantial effect on the rate and extent of $\mathrm{Fe}$ (II) production and the formation of secondary minerals during the bioreduction of lepidocrocite by CN32 [31]. In this study, we examined the effects of a broad range of phosphate concentrations on lepidocrocite bioreduction in systems amended with AQDS. The addition of either $1 \mu \mathrm{M}$ or $10 \mu \mathrm{M}$ phosphate had little effect on the $\mathrm{Fe}$ (II) production profiles compared to the unamended system; the rates of $\mathrm{Fe}(\mathrm{II})$ production and total $\mathrm{Fe}(\mathrm{II})$ concentrations were essentially the same (Figure 15 and Table 4). Likewise, magnetite and chukanovite were the only observed secondary minerals (Figures 16 and 17D). The addition of $100 \mu \mathrm{M}$ phosphate resulted in an order of magnitude decrease in the rate of $\mathrm{Fe}(\mathrm{II})$ production $\left(2.0 \pm 0.1 \mathrm{mM} \cdot \mathrm{day}^{-1}\right.$, compared to $29.9 \pm 1.8 \mathrm{mM} \cdot$ day $^{-1}$ in the $10 \mu \mathrm{M}$ phosphate system), but the final $\mathrm{Fe}(\mathrm{II})$ concentration was nearly double $(55.2 \pm 1.2 \mathrm{mM}$ relative to $31.1 \pm 0.9 \mathrm{mM}$ in the $10 \mu \mathrm{M}$ phosphate system). Green rust was the only secondary mineral evident in the pXRD pattern of the solids remaining at the end of the incubation (Figure 16) and there was no indication of the formation of any transient or intermediate secondary minerals during bioreduction (Figure 18). The hexagonal, platy green rust crystallites had a morphology (Figure 17F) consistent with that of biogenic green rust $[17,18,104]$. These results are essentially the same as what we previously observed in an identical experimental system that was amended with $500 \mu \mathrm{M}$ phosphate [31]. Increasing the phosphate concentration from $100 \mu \mathrm{M}$ to $1 \mathrm{mM}$ resulted in a significant increase in the rate of $\mathrm{Fe}(\mathrm{II})$ production and a small increase in the final Fe(II) concentration (Table 4), and green rust was the only observed secondary mineral (Figures 16 and 17G). The addition of $10 \mathrm{mM}$ phosphate resulted in a biphasic Fe(II) production profile (Figure 15). After an initial pulse of $11.0 \pm 0.8 \mathrm{mM} \mathrm{Fe}$ (II) within the first 0.9 days, $\mathrm{Fe}(\mathrm{II})$ production continued at a sustained rate of $1.9 \pm 0.1 \mathrm{mM} \cdot \mathrm{day}^{-1}$ through until day 30, ultimately leading to the accumulation of $71.4 \pm 4.3 \mathrm{mM} \mathrm{Fe}$ (II) at the end of incubation. At this phosphate concentration, both green rust and vivianite formed as secondary minerals (Figures 16 and $17 \mathrm{H}$ ). 

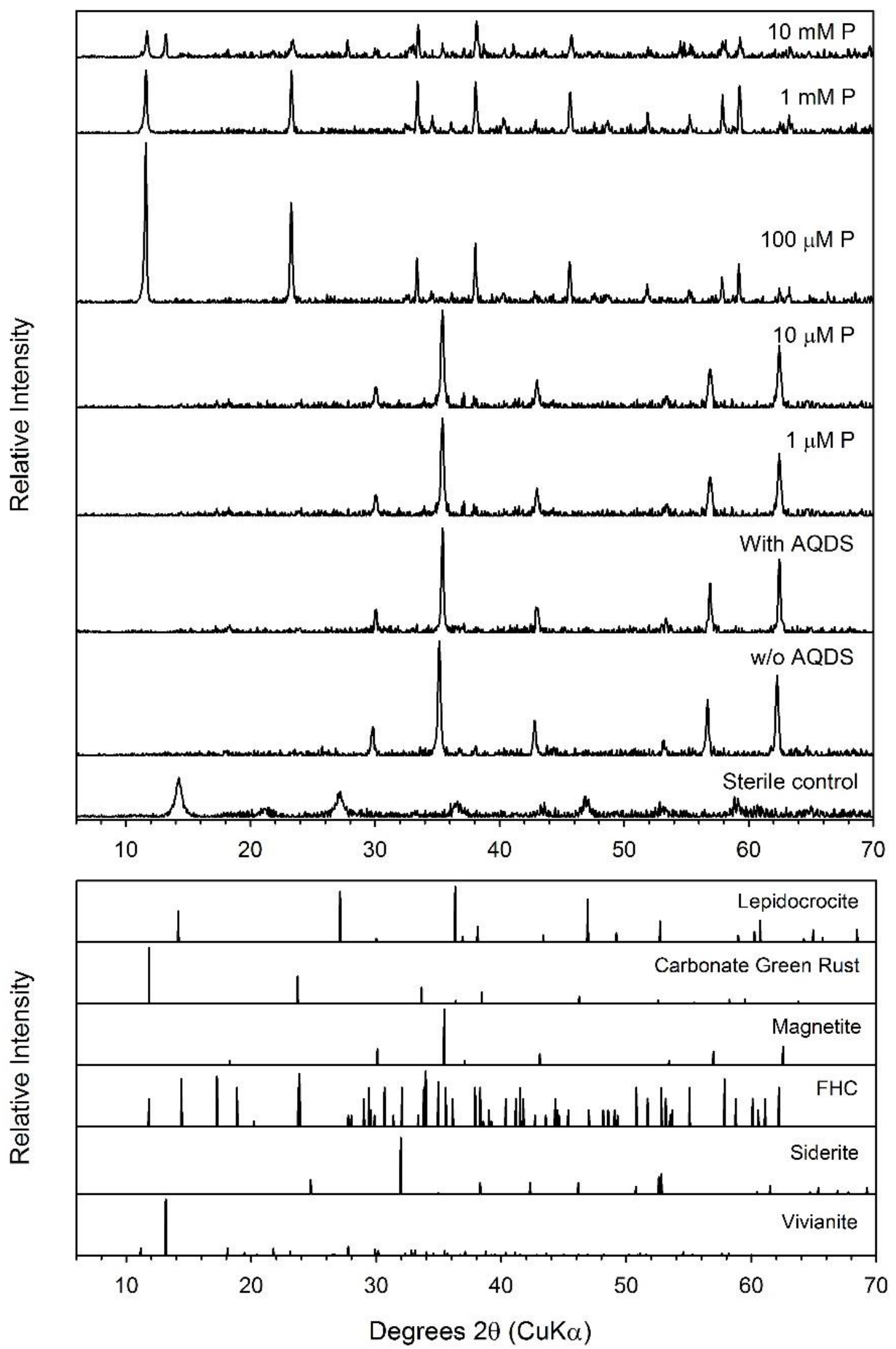

Figure 16. pXRD analysis of the solids in the lepidocrocite (0-10 $\mathrm{mM}$ added phosphate) bioreduction systems at the end of the incubations (79 days). All phosphate-amended systems contained $100 \mu \mathrm{M}$ AQDS. FHC is ferrous hydroxy carbonate (chukanovite). 

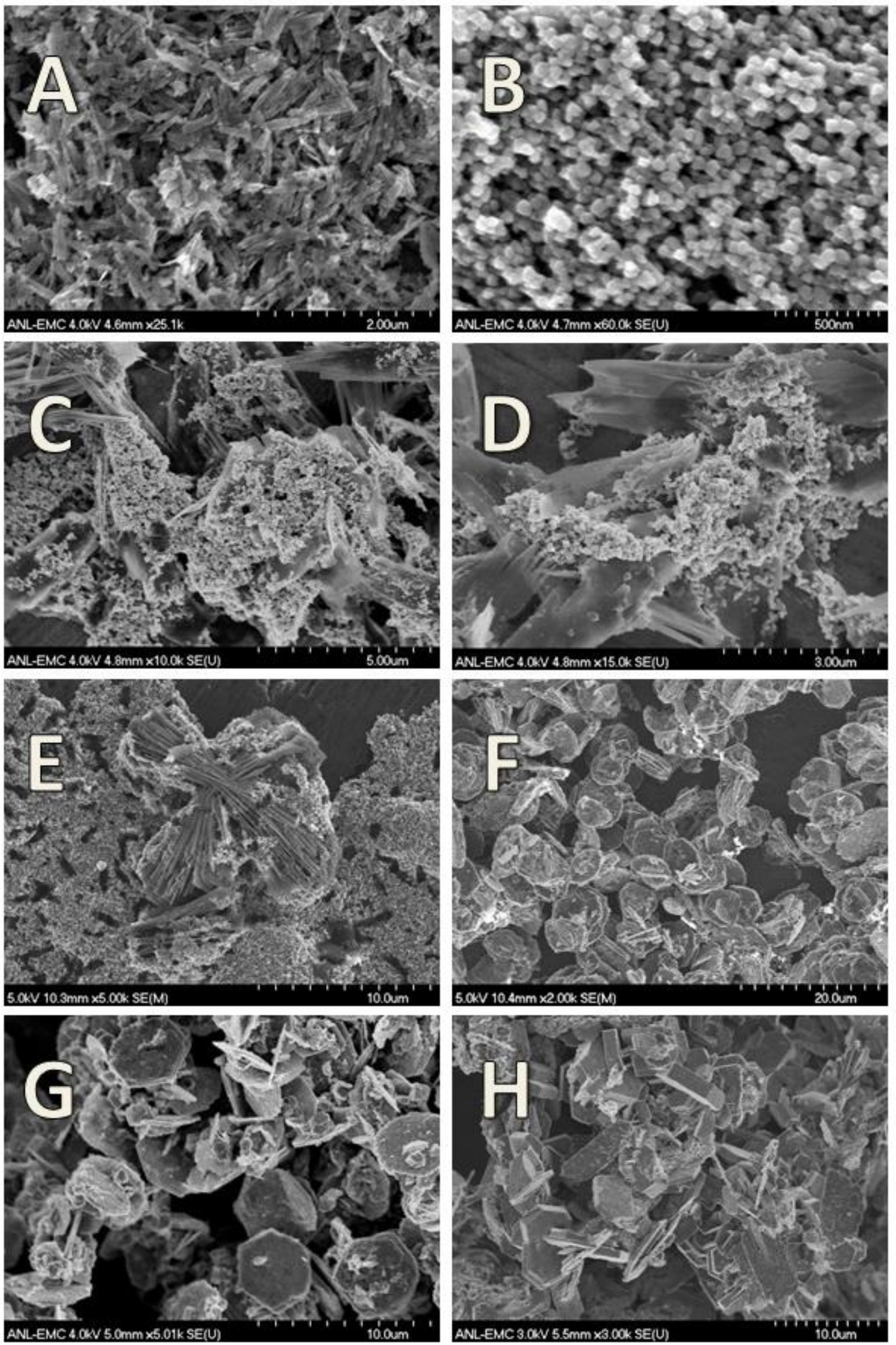

Figure 17. SEM images of the lepidocrocite used in this study (A) and the solids at the end of the incubations with no added phosphate in the absence of AQDS $(\mathbf{B}, \mathbf{C})$ and presence of AQDS with no added phosphate (D), $10 \mu \mathrm{M}$ phosphate (E), $100 \mu \mathrm{M}$ phosphate (F), $1 \mathrm{mM}$ phosphate (G), and $10 \mathrm{mM}$ phosphate $(\mathbf{H})$. The solids in the system amended with $1 \mu \mathrm{M}$ phosphate were identical to those in D. 
Given that there was a clear transition in the rate and extent of $\mathrm{Fe}(\mathrm{II})$ production, as well as the formation of secondary minerals between 10 and $100 \mu \mathrm{M}$ phosphate, we examined lepidocrocite bioreduction over this range of concentrations at a finer scale. The $\mathrm{Fe}(\mathrm{II})$ production profiles (rate and extent) and secondary mineral formation (magnetite and chukanovite) were similar for 0,10 , and $25 \mu \mathrm{M}$ phosphate-amended systems (Figure 19 and Table 4). The results for the systems with $50 \mu \mathrm{M}$ phosphate amendment were similar, except for a short initial lag and slightly higher Fe(II) concentration at the end of the incubation. The addition of $75 \mu \mathrm{M}$ phosphate resulted in distinctly different outcomes between the duplicate bottles. Replicate 1 exhibited an initial lag in $\mathrm{Fe}$ (II) production that was followed by a relatively lower rate of Fe(II) production (compared to the 0, 10, 25, and $50 \mu \mathrm{M}$ treatments); at the end of the incubation, replicate 1 had a slightly higher Fe(II) concentration, and magnetite and chukanovite were the only secondary minerals identified by pXRD and SEM (Figures 20 and 21B). However, the Fe(II) production profile for replicate 2 of the $75 \mu \mathrm{M}$ phosphate treatment was distinctly different from replicate 1 . The rate of $\mathrm{Fe}(\mathrm{II})$ production was much slower and was sustained over a longer period of time, similar to the $100 \mu \mathrm{M}$ treatment. As with the $100 \mu \mathrm{M}$ treatment, replicate 2 had a higher final Fe(II) concentration, and green rust was the only secondary mineral observed by $\mathrm{pXRD}$ and SEM (Figures 20 and 21C). These results suggest a narrow tipping point with respect to phosphate concentration and lepidocrocite bioreduction kinetics, extent, and secondary mineral formation. Below the critical phosphate concentration, Fe(II) production rates are "fast" and magnetite and chukanovite form as secondary minerals, whereas above the critical phosphate concentration, Fe(II) production is slower, the overall extent is greater, and green rust is observed as the sole secondary mineral.

\subsection{Feroxyhyte}

The bioreduction of feroxyhyte was essentially complete within 11 days after inoculation (Figure 22). The rate of Fe(II) production was 5 times faster with the addition of AQDS; however, both AQDS- and AQDS+ systems contained $\sim 24 \mathrm{mM} \mathrm{Fe}(\mathrm{II})$ at the end of the incubation (Table 4). A highly crystalline magnetite, consisting of 50-100 nm nominally cubic crystallites and well-formed bladed chukanovite crystallites, formed in both treatments (Figures 23 and 24B-D), with no indications of other secondary minerals or residual feroxyhyte (Figure 23 and Table 5). There is little information available on secondary minerals resulting from feroxyhyte bioreduction; however, the formation of magnetite in our study is similar to the formation of magnetite during feroxyhyte bioreduction by Geobacter sulfurreducens [26].

The addition of $500 \mu \mathrm{M}$ phosphate greatly inhibited the kinetics of feroxyhyte bioreduction- $0.6 \pm 0.01 \mathrm{mM} \mathrm{Fe}(\mathrm{II})$ day $^{-1}$ compared to $23.3 \pm 3.2 \mathrm{mM} \mathrm{Fe}$ (II) day ${ }^{-1}$ in the system without phosphate-however, the amount of Fe(II) produced by the end of the incubation was two-times greater (Table 4). Magnetite and chukanovite both formed as secondary minerals (Figure 23), but chukanovite was the dominant product (Table 5) and present as poorly formed, irregular crystals (Figure 24E). Increasing the phosphate concentration to $5 \mathrm{mM}$ resulted in a similar bioreduction profile with respect to $\mathrm{Fe}(\mathrm{II})$ production kinetics and final Fe(II) concentration (Figure 22 and Table 4), but in place of magnetite and chukanovite, vivianite and green rust formed as secondary minerals (Figure 23), both of which were poorly developed (i.e., irregular crystallites not exhibiting typical morphologies for green rust or vivianite) (Figure 24F). 


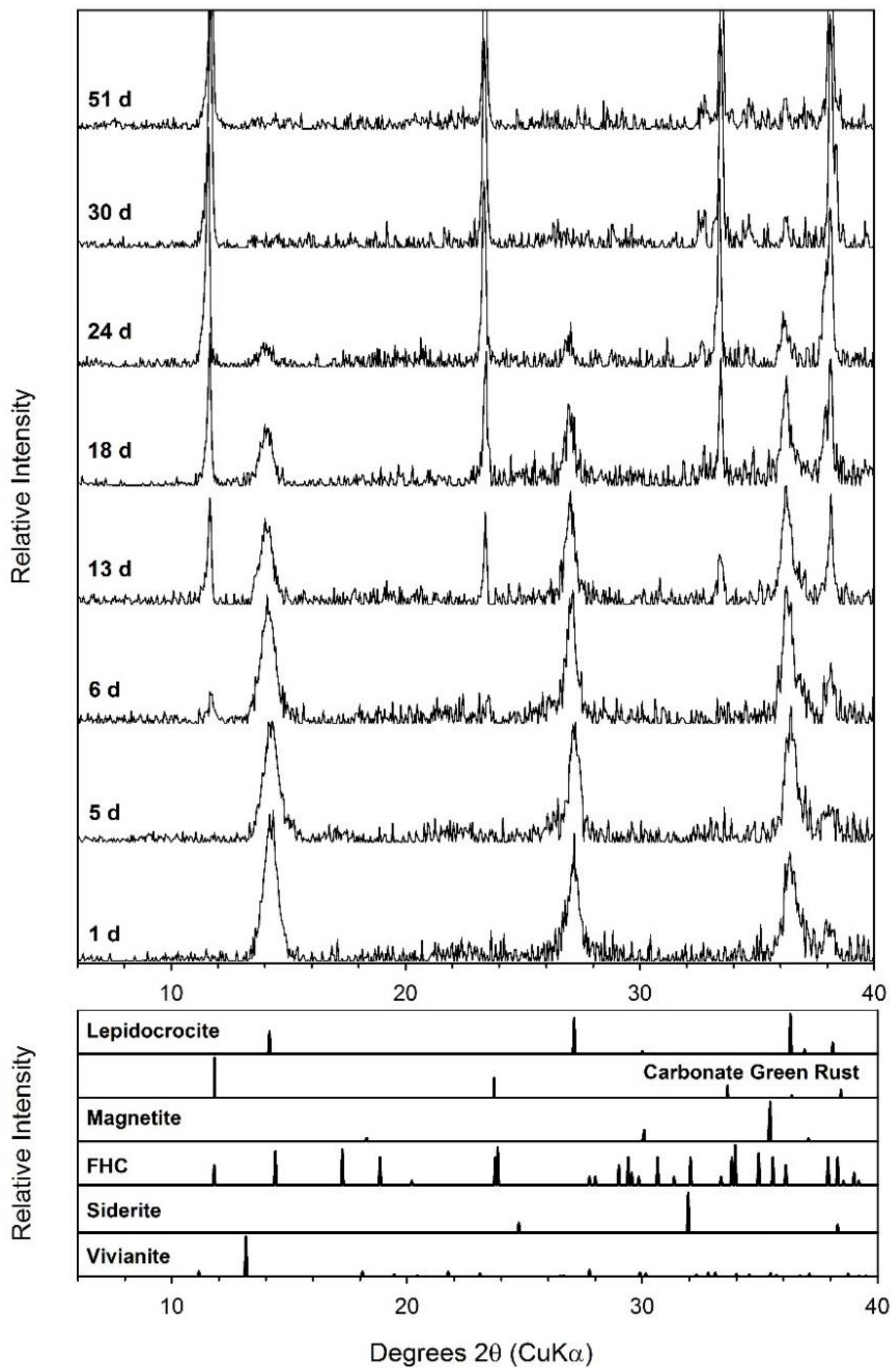

Figure 18. Time series of pXRD analysis of the solids in the $100 \mu \mathrm{M}$ phosphate-amended lepidocrocite bioreduction system. FHC is ferrous hydroxy carbonate (chukanovite). 

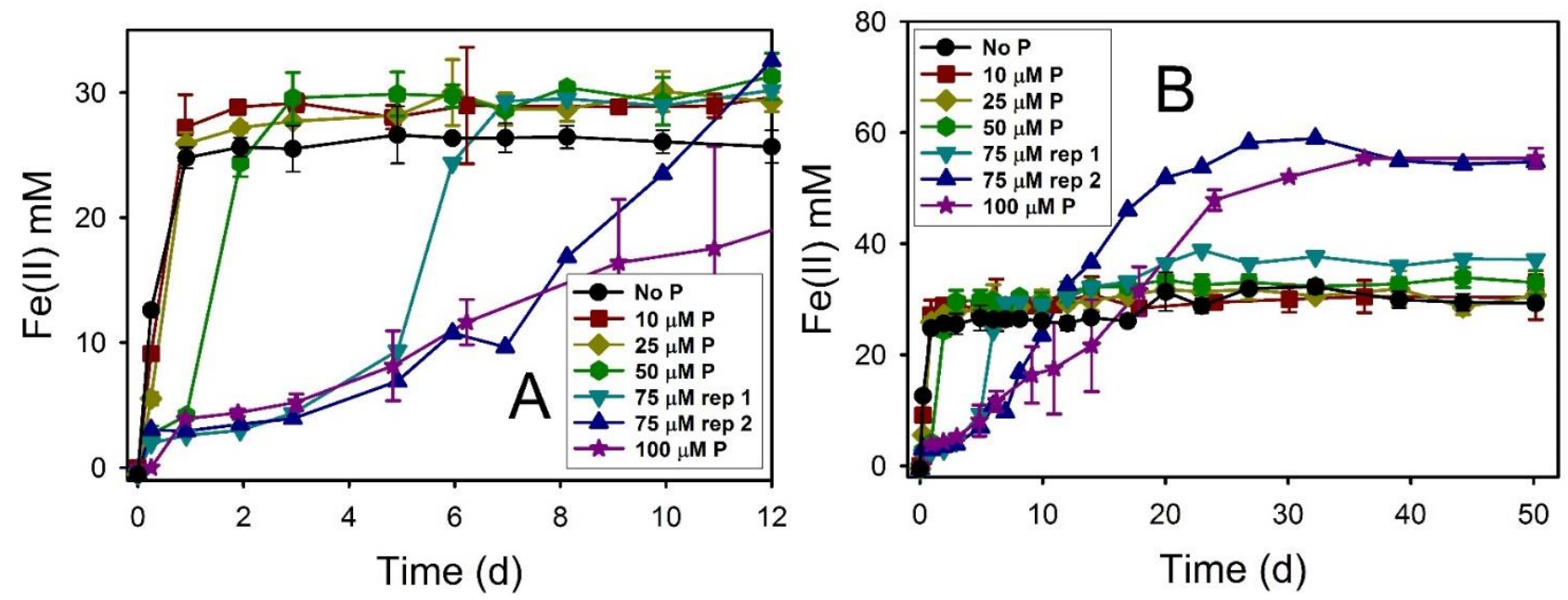

Figure 19. (A) Initial (<12 days) Fe(II) production during the bioreduction of lepidocrocite by S. putrefaciens CN32 and (B) over a period of 51 days. Error bars indicate one standard deviation. All systems contained $100 \mu \mathrm{M}$ AQDS.

\subsection{Ferric Green Rust}

Ferric green rust was readily reduced by CN32 (Figure 25), with an initial Fe(II) production rate of $\sim 19 \mathrm{mM} \cdot$ day $^{-1}$. The presence of AQDS resulted in a nearly 5 -fold increase in the initial rate of $\mathrm{Fe}(\mathrm{II})$ production $\left(\sim 91 \mathrm{mM} \cdot \mathrm{day}^{-1}\right)$, but over time the overall extent of Fe(III) reduction was the same as the non-AQDS-amended system (Figure 25 and Table 4). The addition of $500 \mu \mathrm{M}$ phosphate had no effect on either the rate or extent of $\mathrm{Fe}(\mathrm{II})$ production; however, the maximum rate of sustained $\mathrm{Fe}(\mathrm{II})$ production decreased to $\sim 1 \mathrm{mM} \mathrm{Fe}$ (II) day $^{-1}$ and the final Fe(II) concentration increased by $>70 \%$ in the $5 \mathrm{mM}$ phosphate-amended system (Figure 25 and Table 4).

The bioreduction of ferric green rust by CN32 resulted in the formation of magnetite and chukanovite in all but the $5 \mathrm{mM}$ phosphate system (Table 4). In the absence of added phosphate, highly crystalline magnetite formed in both the AQDS- and AQDS+ systems (Figure 26), and the crystallites were larger $(50-250 \mathrm{~nm}$ ) than the magnetite that formed in any of the other Fe(III) oxide systems we examined (Figure 27B-D). A somewhat less crystalline, finer-grained magnetite was observed in the system amended with $500 \mu \mathrm{M}$ phosphate (Figure 27E). There was little indication of chukanovite in the diffraction patterns of the solids; however, SEM imaging of the solids showed well-formed bladed chukanovite crystals (Figure 27C-E) and Mössbauer analysis indicated that $\sim 15 \%$ and $\sim 27 \%$ of the iron in the solids was present as chukanovite in the AQDS+ systems containing 0 and $500 \mu \mathrm{M}$ phosphate, respectively (Table 5). These results are in contrast to previous studies of the bioreduction of ferric green rust that have reported green rust as the only secondary mineral $[66,101]$. In the $5 \mathrm{mM}$ phosphate-amended system, pXRD and Mössbauer analysis indicated the transformation of ferric green rust to green rust (Figure 26 and Table 5). The green rust crystals were substantially larger than the parent ferric green rust (in some cases, $>5 \mu \mathrm{m}$ across) and in some instances exhibiting the terracing of the layers (Figure 27F-H). 


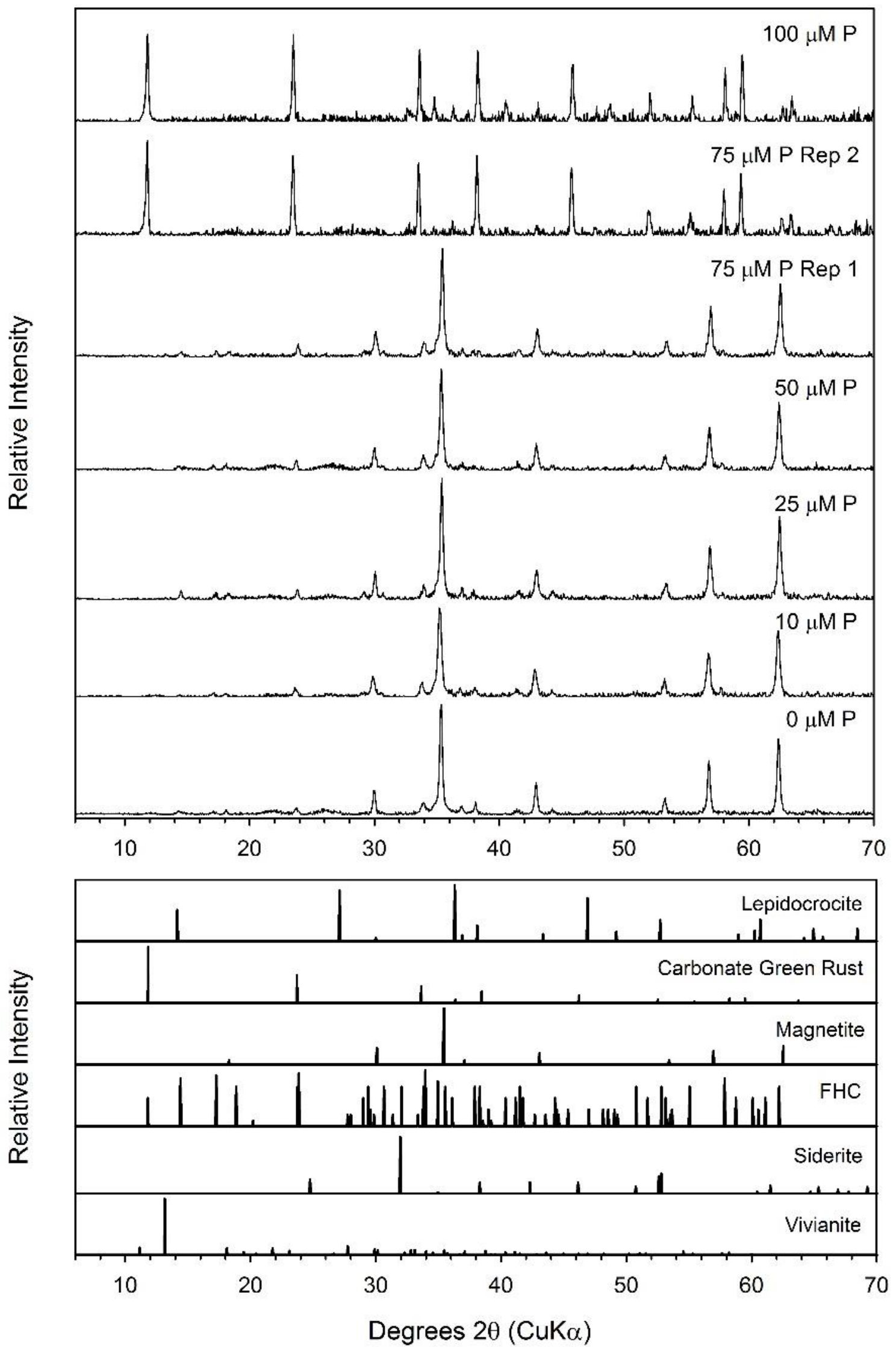

Figure 20. pXRD analysis of the solids in the lepidocrocite $(0-100 \mu \mathrm{M}$ phosphate) bioreduction systems at the end of the incubations (46 days). FHC is ferrous hydroxy carbonate (chukanovite). 

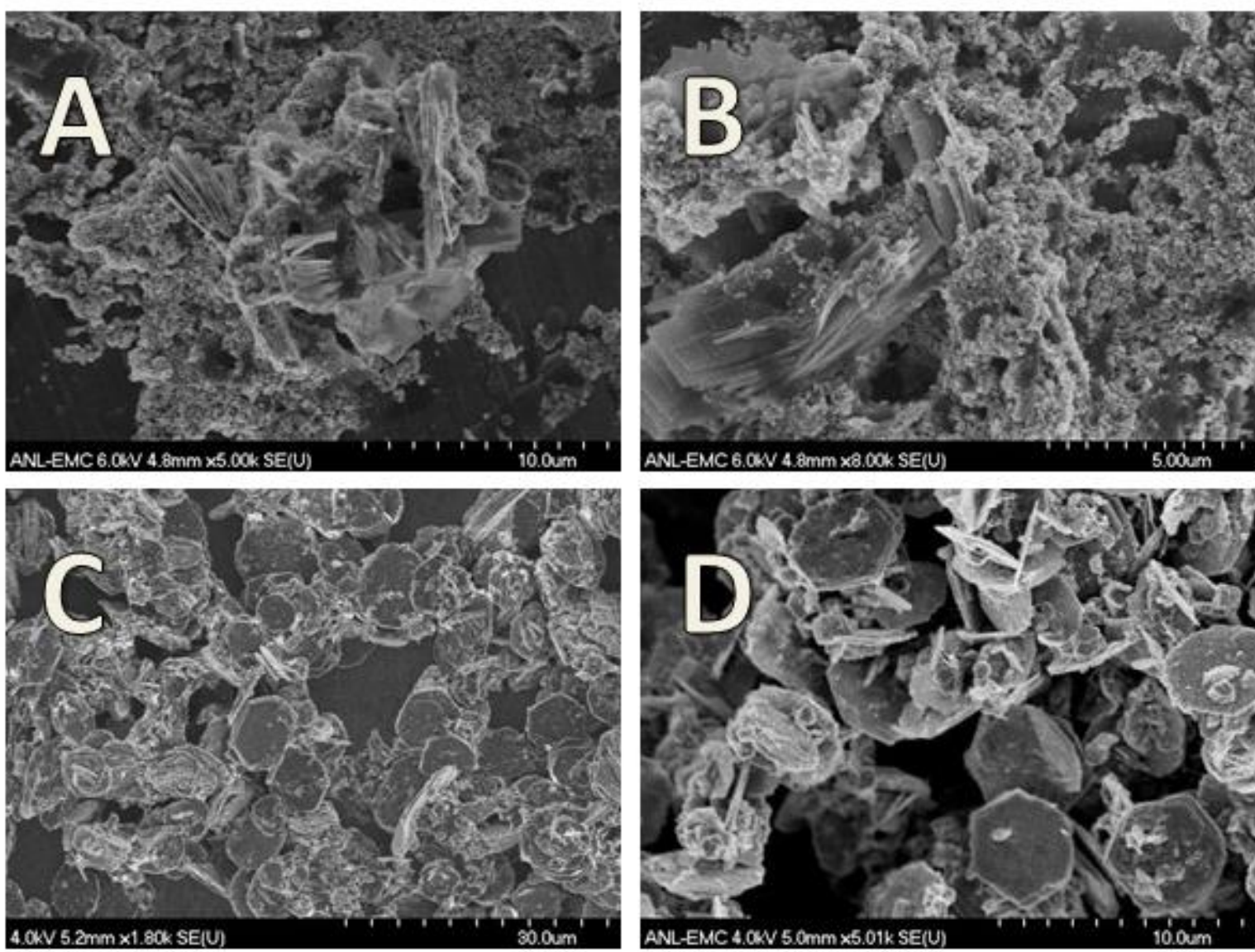

Figure 21. SEM images of the solids at the end of the lepidocrocite bioreduction incubations with $50 \mu \mathrm{M}$ phosphate (A), $75 \mu \mathrm{M}$ phosphate replicate 1 (B), $75 \mu \mathrm{M}$ phosphate replicate 2 (C), and $100 \mu \mathrm{M}$ phosphate (D). The solids in the system amended with $25 \mu \mathrm{M}$ phosphate were identical to those in A.
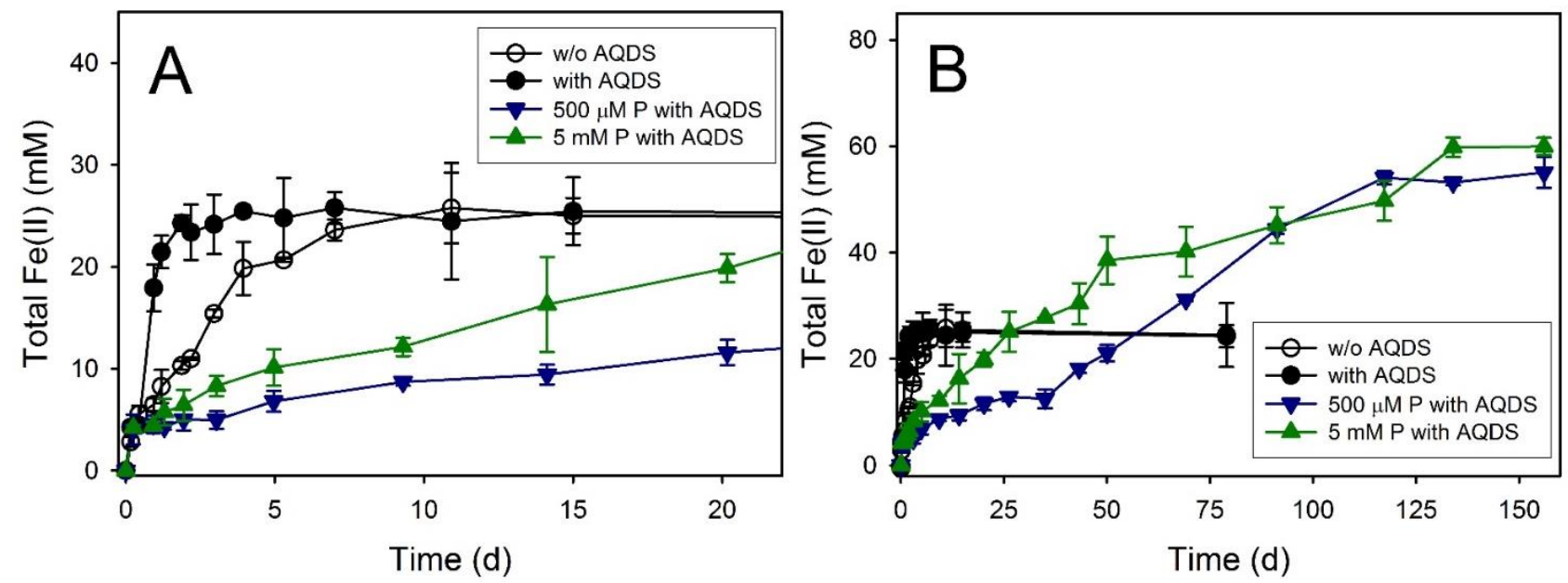

Figure 22. (A) Initial (<22 days) Fe(II) production during the bioreduction of feroxyhyte by S. putrefaciens CN32 and (B) over a period of up to 156 days. Error bars indicate one standard deviation. 

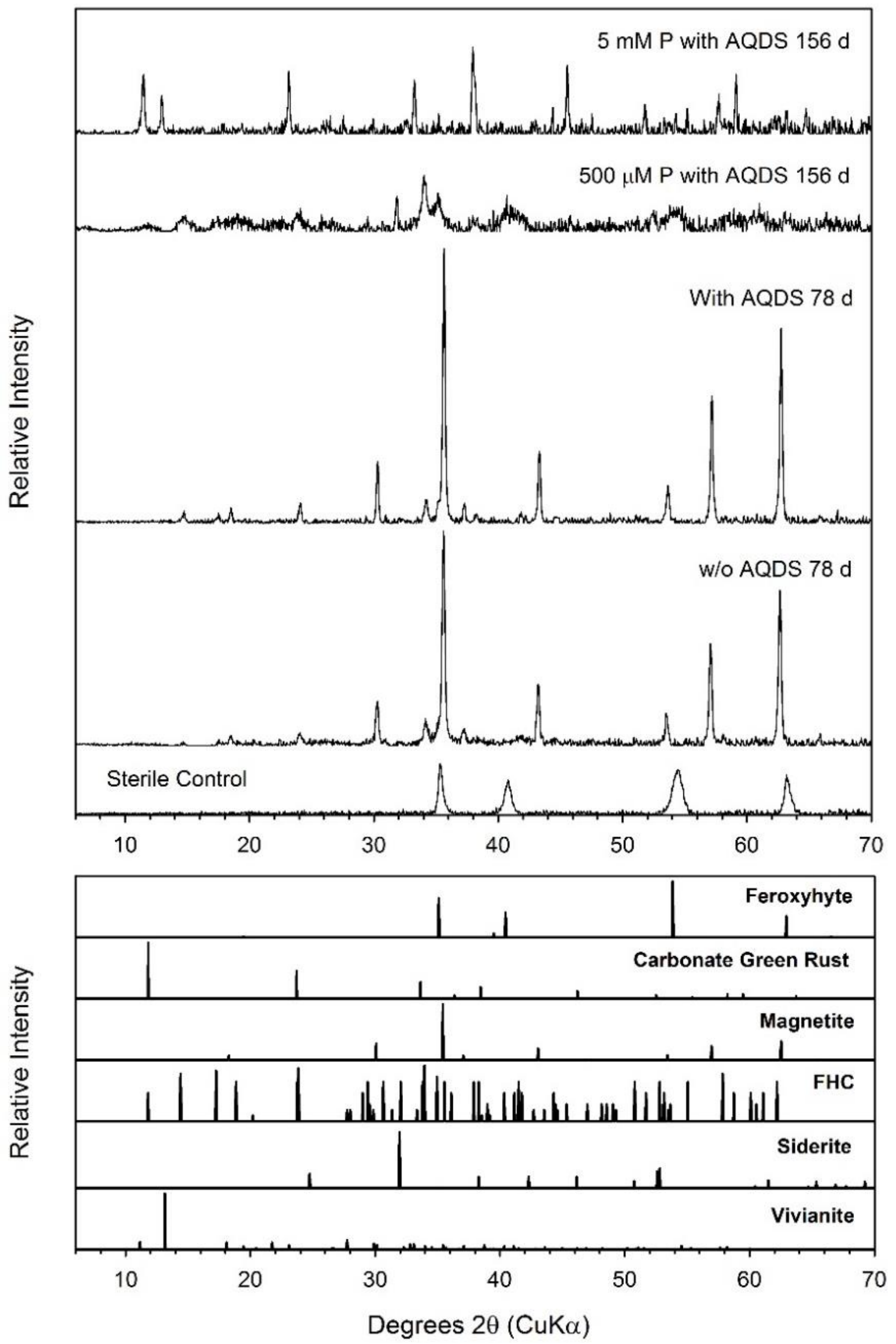

Figure 23. pXRD analysis of the solids in the feroxyhyte bioreduction systems at the end of the incubations (46 days). FHC is ferrous hydroxy carbonate (chukanovite). 

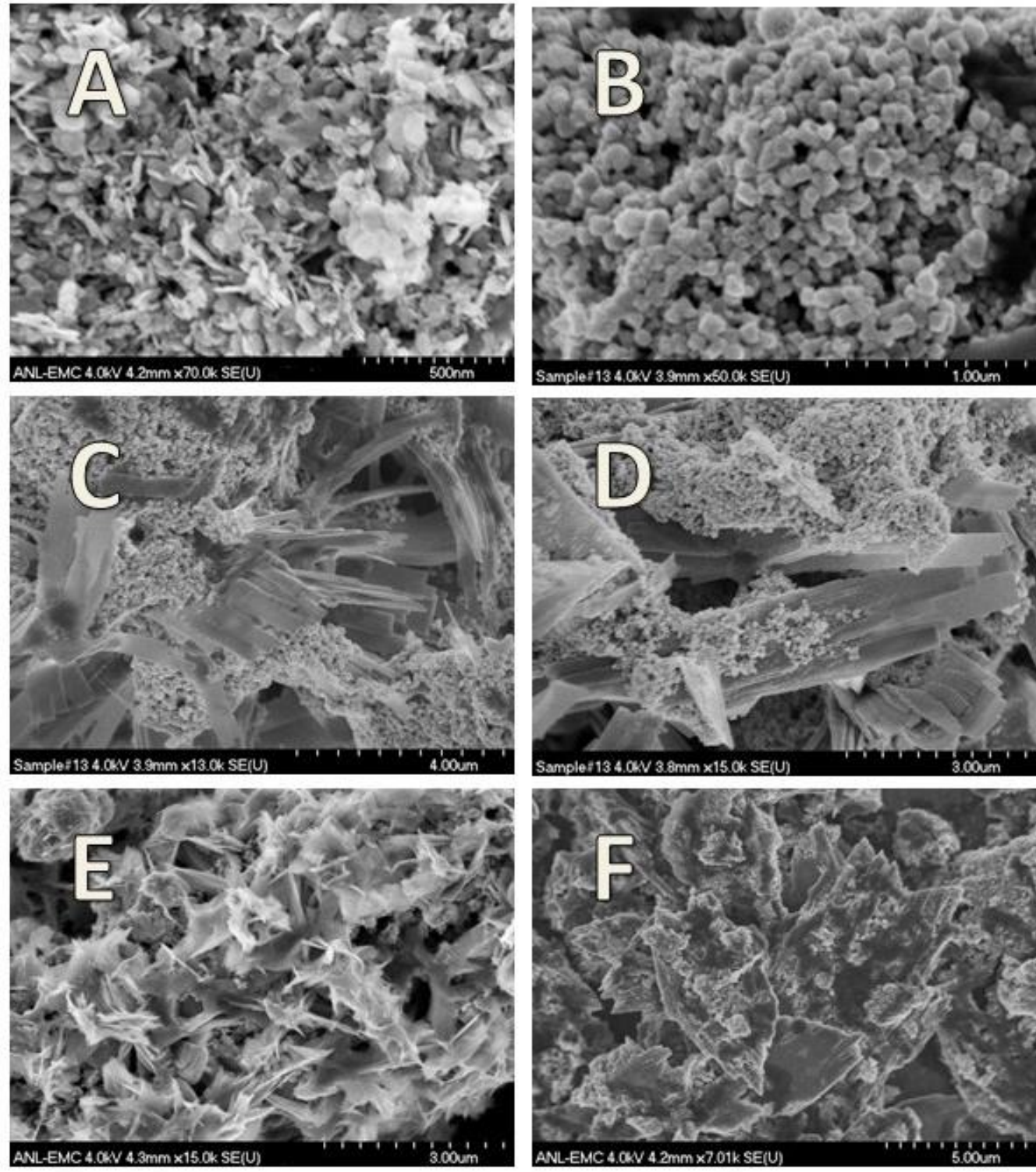

Figure 24. SEM images of the feroxyhyte used in this study $(\mathbf{A})$ and the solids at the end of the incubations in the feroxyhyte bioreduction systems with no added phosphate in the absence of AQDS $(\mathbf{B}, \mathbf{C})$ and presence of AQDS with no added phosphate (D), $500 \mu \mathrm{M}$ phosphate (E), and $5 \mathrm{mM}$ phosphate (F).
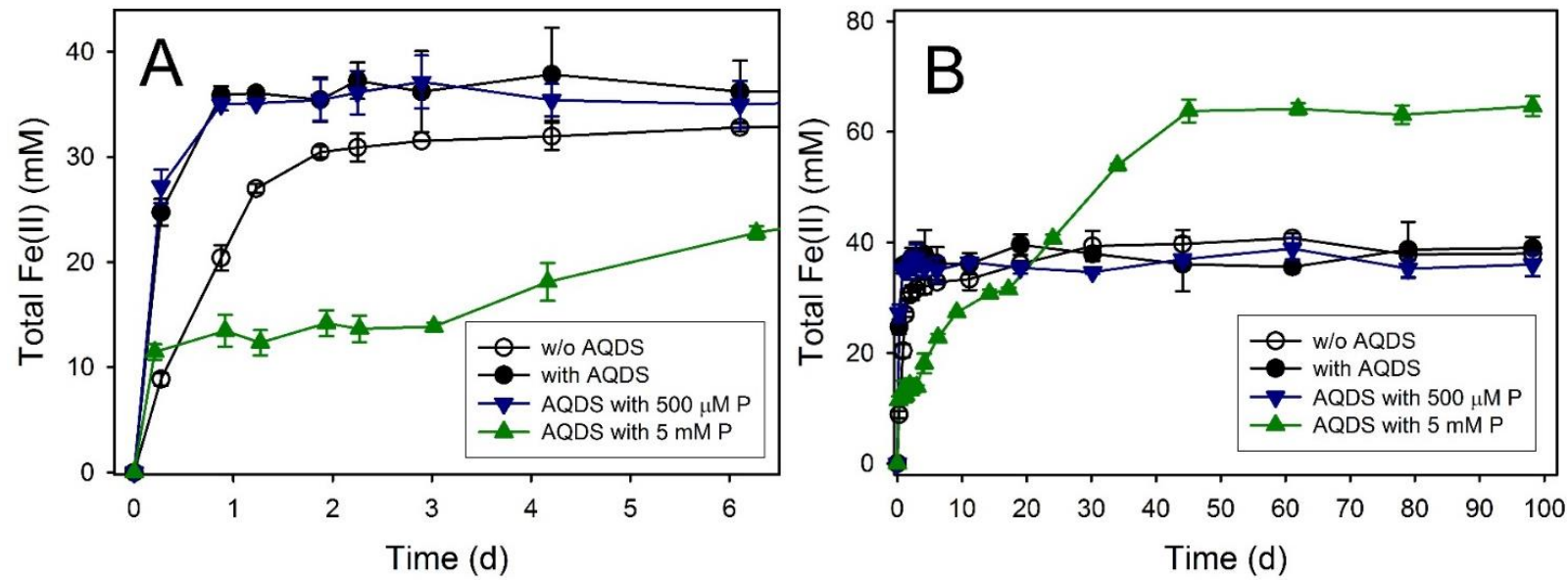

Figure 25. (A) Initial ( $<6.5$ days) Fe(II) production during the bioreduction of ferric green rust by $S$. putrefaciens CN32 and (B) over a period of 98 days. Error bars indicate one standard deviation. 

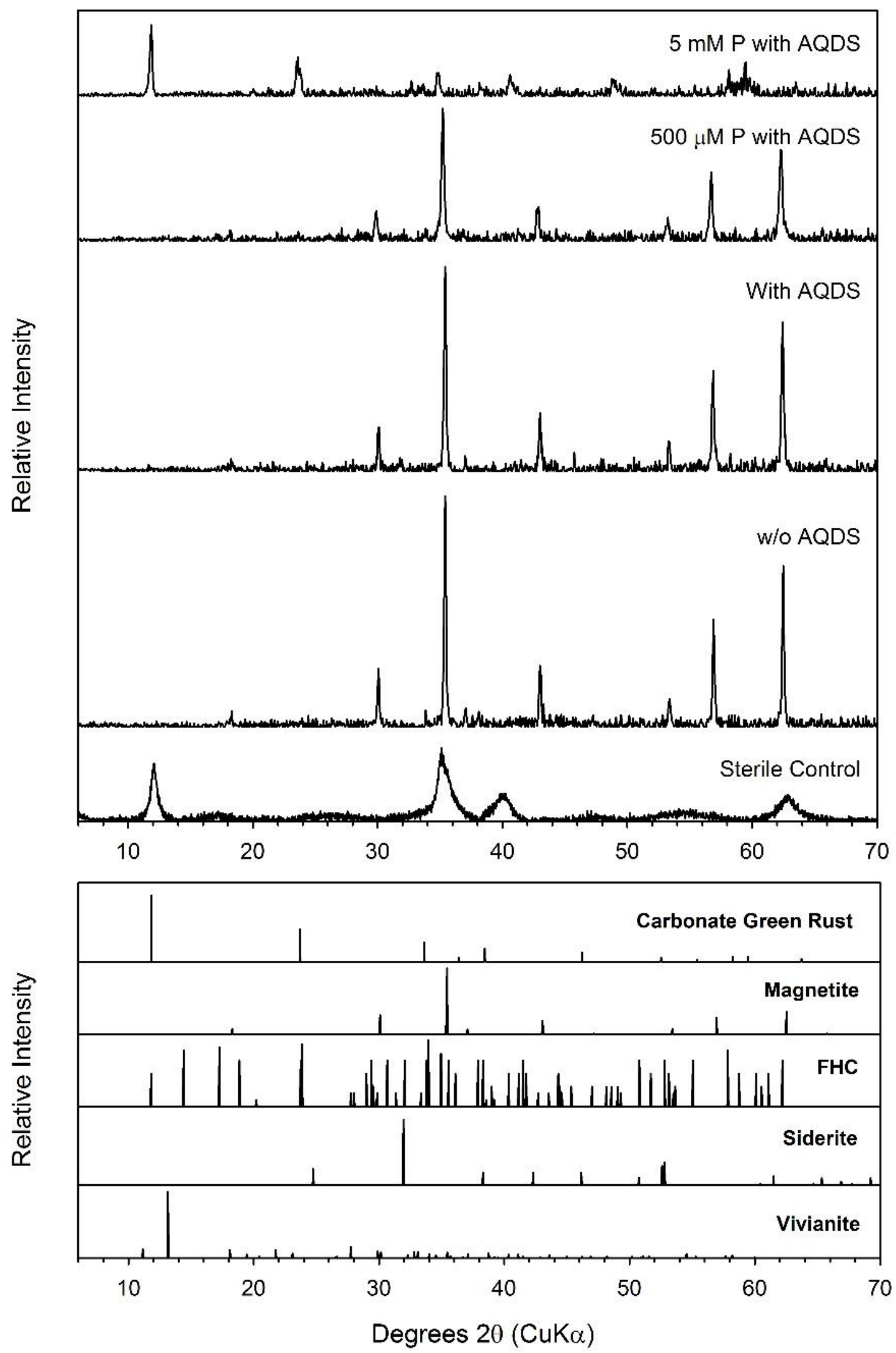

Figure 26. pXRD analysis of the solids in the ferric green rust bioreduction systems at the end of the incubations (98 days). FHC is ferrous hydroxy carbonate (chukanovite). 

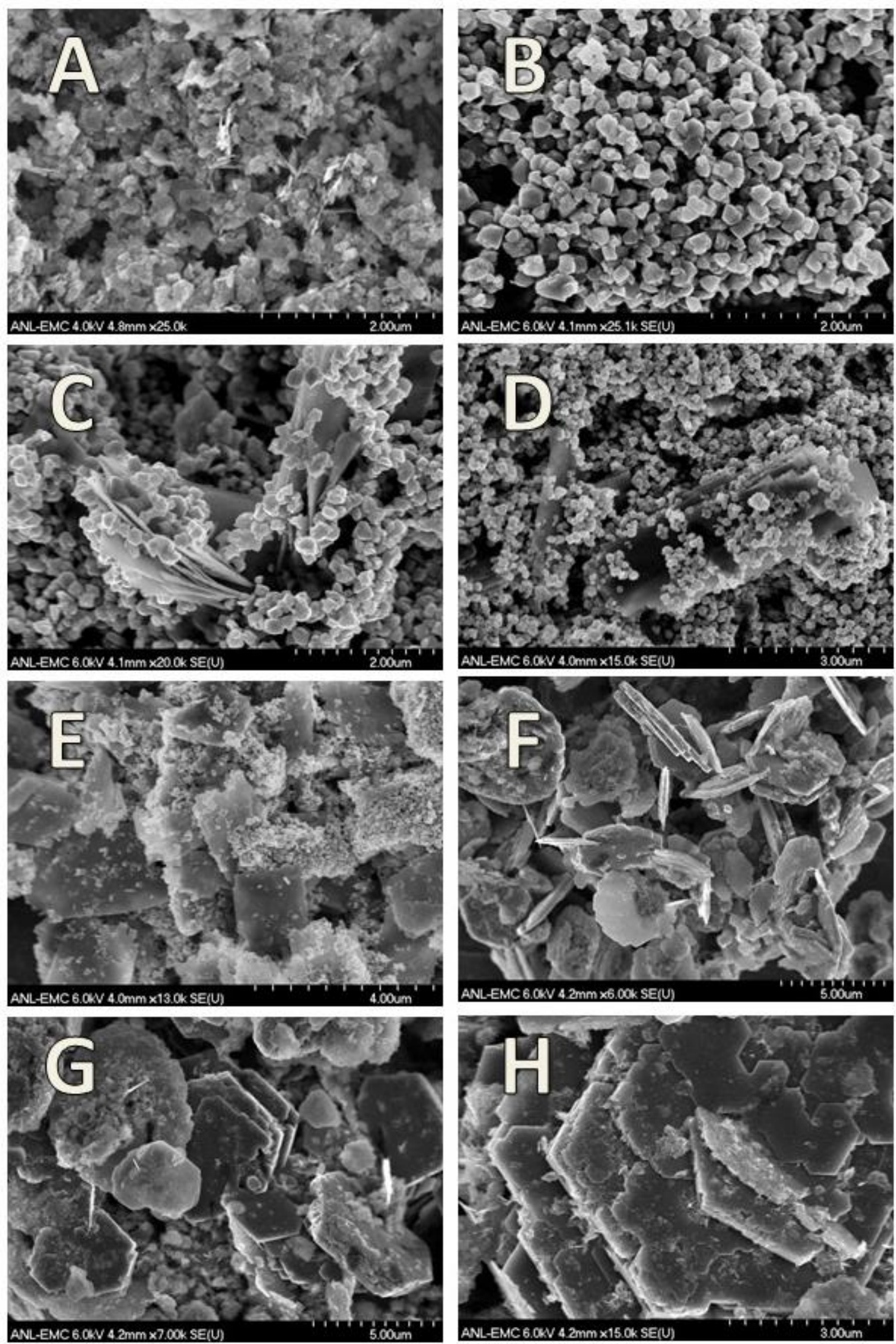

Figure 27. SEM images of the ferric green rust used in this study (A), and the solids at the end of the incubations (98 days) with no added phosphate in the absence of AQDS $(\mathbf{B}, \mathbf{C})$, and presence of AQDS with no added phosphate (D), $500 \mu \mathrm{M}$ phosphate (E), and $5 \mathrm{mM}$ phosphate $(\mathbf{F}-\mathbf{H})$. 
Table 5. Fit parameters from Mössbauer analysis of the secondary minerals in the indicated systems.

\begin{tabular}{|c|c|c|c|c|c|c|}
\hline Sample & Temp (K) & $\mathrm{CS}\left(\mathrm{mm} \cdot \mathrm{s}^{-1}\right)$ & QS $\left(\mathrm{mm} \cdot \mathrm{s}^{-1}\right)$ & $\mathrm{H}(\mathrm{T})$ & Mineral & RA (\%) \\
\hline \multirow{3}{*}{ Feroxyhyte + AQDS } & 77 & 1.30 & 2.29 & & Chukanovite & 21.3 \\
\hline & & 0.39 & -0.01 & 50.7 & Magnetite 1 & 36.6 \\
\hline & & 0.83 & -0.05 & 47.9 & Magnetite 2 & 42.1 \\
\hline \multirow{3}{*}{ Feroxyhyte + AQDS + $500 \mu \mathrm{M} P$} & 77 & 1.29 & 2.34 & & Chukanovite & 62.0 \\
\hline & & 0.58 & -0.07 & 50.6 & Magnetite (oct 2.5) & 19.2 \\
\hline & & 0.38 & -0.08 & 50.0 & Magnetite (tet 3) & 18.8 \\
\hline \multirow{6}{*}{ Ferric Green Rust + AQDS } & 140 & 1.30 & 2.18 & & Chukanovite & 15.0 \\
\hline & & 0.72 & -0.01 & 47.5 & Magnetite (oct 2.5) & 51.2 \\
\hline & & 0.39 & 0.00 & 50.5 & Magnetite (tet 3) & 33.8 \\
\hline & 77 & 1.35 & 2.26 & & Chukanovite & 14.6 \\
\hline & & 0.39 & -0.01 & 50.7 & Magnetite 1 & 40.1 \\
\hline & & 0.83 & -0.05 & 48.0 & Magnetite 2 & 45.3 \\
\hline \multirow{6}{*}{ Ferric Green Rust + AQDS + $500 \mu \mathrm{M} P$} & 140 & 1.26 & 2.20 & & Chukanovite & 26.3 \\
\hline & & 0.77 & -0.02 & 45.6 & Magnetite (oct 2.5) & 46.5 \\
\hline & & 0.37 & 0.00 & 50.2 & Magnetite (tet 3) & 27.3 \\
\hline & 77 & 1.30 & 2.30 & & Chukanovite & 28.7 \\
\hline & & 0.39 & -0.01 & 50.6 & Magnetite 1 & 33.3 \\
\hline & & 0.82 & -0.07 & 47.9 & Magnetite 2 & 38.0 \\
\hline \multirow{4}{*}{ Ferric Green Rust + AQDS + 5 mM P } & 140 & 0.47 & 0.72 & & Green Rust Fe(III) & 20.6 \\
\hline & & 1.27 & 2.78 & & Green Rust Fe(II) & 79.4 \\
\hline & 77 & 0.47 & 0.39 & & Green Rust Fe(III) & 20.7 \\
\hline & & 1.27 & 2.81 & & Green Rust Fe(II) & 79.3 \\
\hline
\end{tabular}

\section{Discussion}

\subsection{Fe(II)-Secondary Mineral Formation in Relation to Parent Fe(III) Oxide in Unamended Systems}

In our experimental systems, the bioreduction of Fe(III) oxides by S. putrefaciens CN32 resulted in the formation of siderite, magnetite, chukanovite, green rust, or vivianite, depending on the experimental conditions. Except for hematite and goethite, magnetite was the dominant secondary mineral observed in the absence of added phosphate. Among the Fe(III) oxides we examined, hematite and goethite had the lowest levels of bioreduction, consistent with previous studies also showing the diminished bioreduction of hematite and goethite, compared to phases such as ferrihydrite, lepidocrocite, akaganeite, and feroxyhyte $[19,26,84,91,105,106]$.

Relative to other Fe(III) oxides, secondary mineral formation during hematite bioreduction has not been widely studied. Behrends and Van Cappellen [22] reported the formation of magnetite and siderite following hematite bioreduction, although magnetite was only observed at bicarbonate concentrations $>5 \mathrm{mM}$. They proposed that the formation of magnetite is dependent on the relative rates of Fe(II) and Fe(III) supply in the aqueous phase, with the rate of soluble Fe(II) production, determined by the bioreduction rate and the rate of soluble Fe(III) formation, determined by the non-reductive dissolution of the hematite- the latter increasing with increasing bicarbonate concentrations. However, Luo et al, [96] examined hematite bioreduction at $<0.1 \mathrm{mM}$ bicarbonate and observed only magnetite. In our experimental system, siderite was the only secondary mineral observed. Although we did not measure bicarbonate concentrations, we can estimate that our system contained at least $3.5 \mathrm{mM}$ carbonate, based on the production of $\sim 7 \mathrm{mM} \mathrm{Fe}$ (II) and the stoichiometry of the reduction of $\mathrm{Fe}$ (III) coupled with formate oxidation (2Fe(III) + $\left.\mathrm{HCO}_{2^{-}}+\mathrm{H}_{2} \mathrm{O}\right) \rightarrow 2 \mathrm{Fe}(\mathrm{II})+\mathrm{HCO}_{3^{-}}+2 \mathrm{H}^{+}$). Therefore, bicarbonate is not the only control determining magnetite formation during the bioreduction of hematite.

As with hematite, studies of secondary mineral formation during goethite bioreduction are rather limited. Although siderite formation is commonly observed under high bicarbonate concentrations (e.g., $30 \mathrm{mM}$ ) [84,93,94], it has also been observed in systems containing as low as $\sim 2 \mathrm{mM}$ bicarbonate [97]. We did not observe siderite in our 
goethite bioreduction experiment, even though at least $11 \mathrm{mM}$ of bicarbonate was generated, based on the amount of Fe(II) produced; rather, chukanovite formed, despite the fact that chukanovite should be metastable, relative to siderite, under our conditions [107]. The formation of chukanovite has been reported in studies of the bioreduction of akaganeite, ferrihydrite, lepidocrocite, and maghemite $[21,27,31,41,66,67,108]$ (as well as for feroxyhyte and ferric green rust, as observed in this study), but not goethite. In these previous studies, magnetite or green rust initially formed as secondary minerals, and chukanovite formation was at their expense, making it essentially a tertiary mineral. In our study, chukanovite truly appears to be a secondary mineral of goethite bioreduction, as no intermediary phases were observed.

Magnetite and chukanovite were secondary minerals of the bioreduction of the remaining Fe(III) oxides (Tables 2 and 4). Magnetite is commonly reported as a product of microbial reduction of akaganeite $[20,21,26,67]$, ferrihydrite $[16,17,28,29,100,109-112]$, lepidocrocite $[26,27,31,41,97,104]$, feroxyhyte [26], and maghemite [66]. The reductive transformation of $\mathrm{Fe}(\mathrm{III})$ oxides to magnetite can occur by either solid-state transformation (topotactic) or dissolution-reprecipitation (reconstruction) mechanisms, depending on the parent $\mathrm{Fe}(\mathrm{III})$ oxide and the experimental conditions. In our experimental system, the transformation of poorly crystalline maghemite to poorly crystalline magnetite was clearly topotactic, given that magnetite is isostructural with maghemite and there was no change in crystallite morphology (Figure 11A,B; note that the pitting evident on the magnetite crystallites was likely due to continued bioreduction). Ferrihydrite is characterized by small crystal size $(<10 \mathrm{~nm})$ and the formation of magnetite of similar size and morphology during ferrihydrite bioreduction has been attributed to topotactic transformation [17,29]. However, magnetite can also form by reconstructive processes [113] that can involve the formation of intermediate Fe phases [114], which result in magnetite specimens having sizes/morphologies different from ferrihydrite. In our experimental system, ferrihydrite transformation resulted in a poorly crystalline and very fine-grained $(\sim 10 \mathrm{~nm})$ magnetite, consistent with a topotactic transformation. However, the magnetite specimens formed during the bioreduction of lepidocrocite, feroxyhyte, and ferric green rust were highly crystalline and likely produced by a dissolution-reprecipitation process, given how dissimilar the morphologies of these magnetites are from their parent Fe(III) oxides. The lepidocrocite used in our study consisted of elongated lath-like crystallites $\sim 10 \mathrm{~nm}$ wide and up to $40 \mathrm{~nm}$ long that were transformed to nominally cubic magnetite $\sim 50 \mathrm{~nm}$ in size. The thin, nominally hexagonal $25-75 \mathrm{~nm}$ wide feroxyhyte crystallites were bioreduced to $50-100 \mathrm{~nm}$ cubic and highly crystalline magnetite. The bioreduction of thin, nominally hexagonal ferric green rust crystallites up to $200 \mathrm{~nm}$ across were reduced to cubic/octahedral magnetite ranging in size from 50 to $250 \mathrm{~nm}$.

The formation of magnetite as a secondary mineral of Fe(III) oxide bioreduction has often been linked to "high" rates of Fe(III) reduction for topotactic transformation, or "high" rates of soluble Fe(II) and Fe(III) supply for transformation by dissolutionprecipitation $[22,28,29]$ and our results are consistent with these observations. In our study, magnetite did not form during hematite or goethite bioreduction, which had maximum $\mathrm{Fe}(\mathrm{II})$ production rates of 0.17 and $0.60 \mathrm{mM} \mathrm{Fe}(\mathrm{II})$ day $^{-1}$, respectively. Conversely, magnetite formed during the bioreduction of all of the other Fe(III) oxides examined, which had maximum Fe(II) production rates, ranging from 4.4 to $62.2 \mathrm{mM} \mathrm{Fe}(\mathrm{II}) \mathrm{day}^{-1}$. Magnetite also formed during the bioreduction of akaganeite in a separate study (13.7 $\mathrm{mM}$ Fe(II) day ${ }^{-1}$ ), under conditions identical to those in this study [67].

\subsection{Impact of $A Q D S$ on $F e(I I)$ Secondary Mineral Formation}

The presence of AQDS has been shown to enhance the rate and often the extent of the bioreduction of a wide range of Fe(III) oxides [17,26,30,32,45,46,55,84,115-118]. In our experimental systems AQDS-enhancement of the rate of Fe(II) production ranged from $11.8 \%$ for hematite to $430 \%$ for feroxyhyte. However, the presence of AQDS did not always lead to an increase in the overall extent of Fe(II) production, as there was no statistically signifi- 
cant difference between AQDS- and AQDS+ treatments in the bioreduction of maghemite, feroxyhyte, and ferric green rust.

Although the presence of electron shuttles almost always results in the enhanced microbial reduction of Fe(III) oxides, there does not appear to be a consistent effect of electron shuttles on secondary mineral formation. Fredrickson et al. [17] and Zachara et al. $[64,84]$ reported that AQDS affects both the types of secondary minerals and their relative crystallinity. Cutting et al. [26] found differences between AQDS- and AQDS+ systems in the relative amounts of goethite and magnetite formed during the bioreduction of akaganeite, lepidocrocite, and schwertmannite. In a previous study, we found that the bioreduction of akaganeite in the presence of AQDS resulted in the formation of a more crystalline magnetite than in its absence. Moreover, most of the magnetite formed in the AQDS+ system was ultimately transformed to chukanovite, but only a minor amount of the magnetite in the AQDS- system was converted to siderite. Conversely, Zegeye et al. [32], O'Loughlin [55], and Coker et al. [117] reported that the presence or absence of AQDS had no effect on the formation of specific secondary minerals during the bioreduction of lepidocrocite or ferrihydrite. The apparent inconsistencies in the effect of AQDS on secondary mineral formation may be due to differences in experimental conditions other than the presence/absence of AQDS.

In this study, AQDS had little effect on the formation of specific secondary minerals; that is, the secondary minerals that formed during the bioreduction of a specific Fe(III) oxide were the same in the presence and in the absence of AQDS (Tables 2 and 4) and there was no apparent difference in their crystallinity. Previous studies identifying chukanovite as a product of $\mathrm{Fe}(\mathrm{III})$ oxide bioreduction have all been in the presence of AQDS $[21,27,31,41,66,108]$. However, we observe chukanovite formation even in the absence of AQDS, indicating that AQDS is not essential for chukanovite formation. The presence of AQDS appears to affect the abundance of chukanovite, as our Mössbauer analysis shows a greater proportion of chukanovite in the AQDS-amended goethite system and there are indications in the pXRD data that AQDS may have enhanced the reduction of magnetite to chukanovite in the ferrihydrite system. It is therefore likely that AQDS significantly affects SMP distribution only in cases when the rate of Fe(II) supply is the major factor in determining biomineral formation.

\subsection{Phosphate Effects on Fe(II) Secondary Mineral Formation}

The effect of phosphate on secondary mineral formation in our experimental systems varied depending on the parent $\mathrm{Fe}(\mathrm{III})$ oxide and the phosphate concentration. In the case of hematite, the presence of $500 \mu \mathrm{M}$ phosphate had no apparent effect, as siderite was the only observed secondary mineral, with or without phosphate. This is in contrast to the study of Yan et al. [95], where the bioreduction of hematite by G. sulfurreducens led to vivianite formation; however, the Fe: $\mathrm{PO}_{4}$ ratio was 1:2 ( 2 $\mathrm{mM}$ Fe and $4 \mathrm{mM}$ phosphate) compared to 160:1 in our study. Behrends and Van Cappellen reported that the presence of both $1 \mathrm{mM}$ and $50 \mathrm{mM}$ phosphate completely inhibited the formation of magnetite as a secondary mineral during the bioreduction of hematite $(\sim 32 \mathrm{mM} \mathrm{Fe})$ by S. putrefaciens strain 200R, with the presumed formation of a ferrous phosphate phase in the system amended with $50 \mathrm{mM}$ phosphate [22]. Similarly, vivianite, but not magnetite, formed during the bioreduction of hematite by S. putrefaciens CN32 [84]. However, magnetite formation during the bioreduction of hematite $(167 \mathrm{mM} \mathrm{Fe})$ by Shewanella oneidensis strain MR-1 was not inhibited in the presence of $3 \mathrm{mM}$ phosphate, as both magnetite and vivianite were observed [96].

In our experimental system, chukanovite was the only secondary mineral that formed during goethite bioreduction in the presence or absence of $500 \mu \mathrm{M}$ phosphate; however, there was a notable increase over time in the crystallinity of goethite in the presence of $500 \mu \mathrm{M}$ phosphate that was accompanied by a change in crystallite morphology from acicular to lath-like. A study of the bioreduction of goethite (either 5, 10, or $100 \mathrm{mM} \mathrm{Fe}$ ) by S. putrefaciens strain CN32 in the presence of $440 \mu \mathrm{M}$ phosphate reported siderite as the only 
secondary mineral indicated by pXRD analysis [93]; however, there was no phosphate-free system for comparison. In a separate study, goethite bioreduction by S. putrefaciens CN32 in the presence of $4 \mathrm{mM}$ phosphate resulted in the formation of siderite and vivianite (with vivianite forming first) compared to siderite alone in the absence of phosphate [84].

The presence of phosphate seemed to have little effect on the bioreduction of maghemite to magnetite. At phosphate concentrations $\leq 1 \mathrm{mM}$, magnetite and chukanovite were the only observed secondary minerals, with roughly equivalent amounts of magnetite and chukanovite in the phosphate-free system and the system with $1 \mathrm{mM}$ phosphate. These results are consistent with a previous study showing that the presence of $0.21 \mathrm{wt} \%$ (as P) structural phosphate in maghemite had no effect on secondary mineral formation [66]. However, in the presence of $10 \mathrm{mM}$ phosphate, magnetite and vivianite formed, with no indication of chukanovite. As the transformation of maghemite to magnetite is topotactic, it is perhaps not surprising that phosphate did not seem to inhibit magnetite formation, even as the phosphate loading on maghemite reached the sorption capacity (Table 6). The formation of vivianite in the $10 \mathrm{mM}$ phosphate system is consistent with the high concentration of phosphate remaining in solution $(\sim 9 \mathrm{mM})$ after phosphate sorption by maghemite.

As discussed in Section 4.1, magnetite and chukanovite were observed as secondary minerals during the bioreduction of ferrihydrite, lepidocrocite, feroxyhyte, and ferric green rust in the absence of phosphate. Several previous studies have shown a close association between the presence of phosphate and the formation of green rust at the expense of magnetite during the reduction of ferrihydrite, lepidocrocite, and akaganeite by IRB $[17,31,40,65-67]$ However, most of these studies have been binary in their approach; i.e., phosphate was either absent or present at a single concentration/loading, and even those that have examined phosphate effects at multiple concentrations offer limited insight as to the sorption density or aqueous concentration range over which phosphate inhibits magnetite formation; either because magnetite was inhibited even at the lowest phosphate concentration/loading examined or by the presence of other similar oxyanions (e.g., silicate) $[39,40,66]$. In our study, we observe clear phosphate concentration effects on the formation of magnetite versus green rust; magnetite and chukanovite formed at phosphate concentrations of $\leq 1 \mathrm{mM}$ (ferrihydrite), < 100 $\mu \mathrm{M}$ (lepidocrocite), $500 \mu \mathrm{M}$ (feroxyhyte and ferric green rust), while green rust, or green rust and vivianite, formed at phosphate concentrations of $10 \mathrm{mM}$ (ferrihydrite), $\geq 100 \mu \mathrm{M}$ (lepidocrocite), and $5 \mathrm{mM}$ (feroxyhyte and ferric green rust).

Phosphate binds strongly to $\mathrm{Fe}(\mathrm{III})$ oxides through the formation of inner-sphere complexes [119] that are known to affect the stability and subsequent transformations of Fe(III) oxides (including biotic and abiotic reduction) [39,120,121]. As such, the extent of phosphate sorption to an Fe(III) oxide may have some bearing on the formation of specific secondary minerals. This is clearly the case for vivianite, a ferrous phosphate mineral. Vivianite is commonly reported in systems where phosphate loadings are high enough to maintain solution phase phosphate concentrations that support vivianite precipitation. For example, in our study, vivianite was only observed in systems where the equilibrium solution phase phosphate concentrations of $>4 \mathrm{mM}$ are expected (Table 6). It is less clear how phosphate sorption affects the formation of green rust versus magnetite. We observed a level of phosphate coverage for ferrihydrite, lepidocrocite, and feroxyhyte, below which magnetite (and chukanovite) formed and above which green rust (and vivianite) formed (Table 6); however, the threshold level was specific to each Fe(III) oxide. Borch et al. [39] examined secondary mineral formation during ferrihydrite bioreduction by $S$. putrefaciens CN32 under conditions of $0 \%, 50 \%$, and $100 \%$ phosphate coverage. Both magnetite and green rust were observed at $0 \%$ and $50 \%$ coverage, but only green rust formed at $100 \%$ coverage. The differences between their study and ours are noteworthy in two respects. First, they observed green rust formation in the absence of phosphate, and second, both green rust and magnetite were observed in the same system. In our experiments, we never observed magnetite and green rust in the same system; indeed, magnetite formed in one replicate bottle in the system containing lepidocrocite and $75 \mu \mathrm{M}$ phosphate, and 
green rust formed in the other (Table 4). It is also worth noting that the effect of the extent of phosphate coverage varied among the Fe(III) oxides; for example, phosphate coverage of nearly $70 \%$ capacity had no effect on the secondary minerals that formed in the hematite and goethite systems, while a completely different secondary mineral formed in the lepidocrocite system, with coverage as low as $7 \%$ capacity (Table 6). Furthermore, green rust was never observed as a product of maghemite bioreduction, even at nominal coverage $>100 \%$ of the calculated capacity (Table 6). As we discuss in the next section, other factors, in addition to phosphate concentration, have been identified as potentially contributing to the formation of green rust during Fe(III) oxide bioreduction, and both our study and that of Borch et al. [39] did not examine phosphate effects in the absence of some of these other factors. As such, our results offer only partial insight into the effects of phosphate on secondary mineral formation.

Table 6. Phosphate sorption on Fe(III) oxides.

\begin{tabular}{|c|c|c|c|c|c|c|c|}
\hline System & $\begin{array}{l}\text { Total Added } \\
\text { Phosphate } \\
\text { (mM) }\end{array}$ & $\begin{array}{l}\text { Phosphate in } \\
\text { Solution after } \\
48 \mathrm{~h}(\mathrm{mM})\end{array}$ & $\begin{array}{l}\text { Amount of } \\
\text { Phosphate } \\
\text { Sorbed (\%) }\end{array}$ & $\begin{array}{c}\text { Amount of Phosphate } \\
\text { Sorbed Per Surface } \\
\text { Area }\left(\mu \mathrm{mol} \cdot \mathrm{m}^{-2}\right)\end{array}$ & $\begin{array}{l}\text { Phosphate } \\
\text { Sorption Capacity } \\
\left(\mu \mathrm{mol} \cdot \mathrm{m}^{-2}\right)\end{array}$ & $\begin{array}{c}\text { Fraction of } \\
\text { Sorption } \\
\text { Capacity Occupied }\end{array}$ & $\begin{array}{c}\text { Secondary } \\
\text { Minerals } \\
\text { Observed }\end{array}$ \\
\hline Hematite & 0.500 & 0.271 & 45.9 & 1.64 & 2.40 & 0.68 & Sid \\
\hline Goethite & 0.500 & $\mathrm{ND}^{\mathrm{b}}$ & 100 & 1.38 & 2.10 & 0.66 & Chuk \\
\hline \multirow{4}{*}{ Maghemite } & 0.010 & ND & 100 & 0.02 & \multirow[t]{4}{*}{1.80} & 0.01 & Mag/Chuk \\
\hline & 0.100 & ND & 100 & 0.20 & & 0.11 & Mag/Chuk \\
\hline & 1.000 & 0.068 & 93.2 & 1.83 & & 1.02 & Mag/Chuk \\
\hline & 10.000 & 8.997 & 10 & 1.97 & & 1.09 & $\mathrm{Mag} / \mathrm{Viv}$ \\
\hline \multirow{4}{*}{ Ferrihydrite } & 0.010 & ND & 100 & $<0.01$ & \multirow[t]{4}{*}{3.10} & $<0.01$ & Mag/Chuk \\
\hline & 0.100 & ND & 100 & 0.04 & & 0.01 & Mag/Chuk \\
\hline & 1.000 & ND & 100 & 0.44 & & 0.14 & Mag/Chuk \\
\hline & 10.000 & 4.854 & 51.5 & 2.28 & & 0.73 & GR/Viv \\
\hline \multirow{6}{*}{ Lepidocrocite } & 0.001 & ND & 100 & $<0.01$ & \multirow[t]{6}{*}{2.60} & $<0.01$ & Mag/Chuk \\
\hline & 0.010 & ND & 100 & 0.02 & & 0.01 & Mag/Chuk \\
\hline & 0.100 & ND & 100 & 0.19 & & 0.07 & GR \\
\hline & 0.500 & ND & 100 & 0.96 & & 0.37 & GR \\
\hline & 1.000 & 0.373 & 62.7 & 1.21 & & 0.46 & GR \\
\hline & 10.000 & 9.126 & 8.7 & 1.68 & & 0.73 & GR/Viv \\
\hline \multirow{2}{*}{ Feroxyhyte } & 0.500 & ND & 100 & 1.10 & \multirow[t]{2}{*}{2.50} & 0.44 & Mag/Chuk \\
\hline & 5.000 & 4.207 & 15.9 & 1.72 & & 0.70 & GR/Viv \\
\hline \multirow[b]{2}{*}{ Ferric Green Rust } & 0.500 & ND & 100 & 0.63 & \multirow[t]{2}{*}{-} & - & Mag/Chuk \\
\hline & 5.000 & 2.104 & 57.9 & 3.66 & & - & GR/Viv \\
\hline Akaganeite & 0.500 & ND & 100 & 2.30 & 6.20 & 0.37 & GR \\
\hline
\end{tabular}

${ }^{\text {a }} \mathrm{Fe}(\mathrm{II})$ Phosphate sorption capacity values are from Borggaard [121]. ${ }^{\mathrm{b}}$ ND, non-detectable $(<0.0097 \mu \mathrm{M})$.

\subsection{Formation of Green Rust as a Secondary Mineral during Fe(III) Oxide Bioreduction}

The formation of green rust as a secondary mineral during the bioreduction of Fe(III) oxides was first reported by Fredrickson et al. during the reduction of ferrihydrite by $S$. putrefaciens CN32 [17]. Since then, green rusts have been reported as products of the microbial reduction of $\mathrm{Fe}(\mathrm{III})$ oxides in laboratory-based studies under a wide range of experimental conditions $[12,18,19,23,27,29,31-33,36,38-41,55,65,101,108,118,122-124]$. In addition to the presence/concentration of phosphate, other factors have been proposed to contribute to the formation of green rusts during Fe(III) oxide bioreduction, including the presence of other oxyanions (arsenate, silicate, molybdate, tungstate, etc.) [31,41]; the presence and nature of dissolved organic carbon (including humic substances and microbially produced extracellular polymeric materials) [31,33,38]; the species and population size of IRB [31-33]; the type and concentration of the electron donor [18,36,37]; the rate and extent of Fe(II) production $[17,19,125]$; the presence of electron shuttles [17]; the sorption of Fe(II) to the parent $\mathrm{Fe}(\mathrm{III})$ oxide [25]; the extent of aggregation of Fe(III) oxide particles [27]; $\mathrm{Fe}(\mathrm{III})$ oxide mineralogy (this study). Despite over 20 years of investigation, a definitive and comprehensive understanding of the key factor(s) and mechanisms of green rust formation during microbial Fe(III) oxide reduction remains elusive. However, the factors mentioned above do suggest some common themes; in particular, mineralogical characteristics of specific Fe(III) oxides, sorbate interactions, and bioreduction rate. 
Green rusts form as secondary minerals during the microbial reduction of many Fe(III) oxides, including ferrihydrite ([19,29,33,36,39,40,65,122,126] and this study), lepidocrocite ([12,18,27,31,32,41,55,66,101,104,108,118,123] and this study), mixtures of ferrihydrite and lepidocrocite [23,38], akaganeite [67], magnetite [124], schwertmannite [127], and ferric green rust $([66,101]$ and this study). Our study shows that green rust can also form during the bioreduction of feroxyhyte. However, green rusts have not been reported to form during the bioreduction of hematite, goethite, and maghemite. Usman et al. [128] have shown that green rust can be formed via the abiotic reductive transformation of goethite and hematite by $\mathrm{Fe}(\mathrm{II})$, which they attribute to careful control of the experimental conditions, which included the addition of Fe(II) at a level consistent with the 2:1 stoichiometric ratio of $\mathrm{Fe}(\mathrm{II}): \mathrm{Fe}(\mathrm{III})$ in green rust and the addition of $\mathrm{NaOH}$ to provide an $\mathrm{OH}^{-}: \mathrm{Fe}(\mathrm{III})$ ratio of 3 (final $\mathrm{pH} \sim 6.3$ ). Given the high levels of $\mathrm{Fe}(\mathrm{II})$ required for the transformation of goethite and hematite to green rust, it is perhaps not surprising that green rust has not been observed as a product of the bioreduction of either Fe(III) oxide, given the comparatively low levels (and perhaps slow kinetics) of Fe(II) that are typically reported ([26,84,89-91] and this study). Currently, there are no reports of the biotic or abiotic reduction of maghemite to green rust and it is unclear if this is because this topic has not been well studied or because the process does not happen; however, Etique et al. [124] have reported the formation of green rust as a secondary mineral during the bioreduction of magnetite, which suggest that it is the former, as maghemite is readily reduced to magnetite.

Several studies have proposed a link between the rate of Fe(II) production and the formation of green rust relative to other secondary minerals (e.g., magnetite and siderite) $[17,19,28,31,32,125]$. Indeed, a clear delineation was observed between "fast" Fe(II) production kinetics and magnetite formation versus green rust formation with "slow" $\mathrm{Fe}(\mathrm{II})$ production rates during the bioreduction of lepidocrocite [31,125]. In this study we did not observe a clear correlation between Fe(II) production rate and green rust formation. During the bioreduction of ferrihydrite, feroxyhyte, ferric green rust, and lepidocrocite, we observed rates of $\mathrm{Fe}$ (II) production from $0.6-100 \mathrm{mM} \mathrm{Fe}(\mathrm{II}) \mathrm{d}^{-1}$ in systems where magnetite formed, and from $0.7-72 \mathrm{Fe}(\mathrm{II}) \mathrm{d}^{-1}$ in systems where green rust formed (Tables 2 and 4). As such, it appears that the $\mathrm{Fe}(\mathrm{II})$ production rate alone is not the determining factor for GR formation, but in some cases it may be an indicator of other processes having more direct control on secondary mineral formation.

The surfaces of $\mathrm{Fe}(\mathrm{III})$ oxides are effective sorbents for a wide range of ligands found in various natural and engineered environments, and several of the studies showing green rust formation during Fe(III) oxide bioreduction suggest that the presence of many of these ligands favors green rust formation, typically at the expense of magnetite. As already discussed, green rust formation has been linked to phosphate concentration. The presence of other oxyanions, such as silicate, arsenate, molybdate, and tungstate, also favor green rust formation [31,41]; however, borate, even at higher surface coverage, does not [31]. Likewise, there are differences in the effects of various organic ligands. Among low molecular mass organic acids, green rust formed in the presence of citrate, but not oxalate [31]. Among humic substances (a class of naturally occurring, chemically heterogeneous organic oligoelectrolytes, derived primarily from the decomposition of bacteria, algae, and higher plant material that are ubiquitous in aquatic and terrestrial environments), the formation of green rust was favored in the presence of humics with greater aromatic content and larger molecular weights, while magnetite formed in the presence of humics with higher levels of polypeptides and polysaccharides [31]. Bacteria produce EPS (a heterogeneous mixture of polysaccharides, proteins, lipids, and nucleic acids), which sorb to iron oxides, and EPS from IRB has been shown to favor the formation of green rust $[31,33]$. Furthermore, IRB themselves associate with Fe(III) oxide surfaces $[129,130]$, and high cell numbers of IRB also tend to favor green rust formation [27,31,32]; however, the specific cell density, leading to green rust formation, seems to be species dependent $[31,33]$.

Although there have been numerous studies examining the link between ligand sorption on $\mathrm{Fe}(\mathrm{III})$ oxides and green rust formation during microbial Fe(II) oxide reduction, 
the processes leading to the formation of green rust versus magnetite are still unclear. Green rust has been reported as a metastable intermediate in the abiotic formation of magnetite following the sorption of $\mathrm{Fe}(\mathrm{II})$ to lepidocrocite [131] or ferrihydrite $[62,132,133]$ in aqueous suspensions. However, the presence of ligands such as phosphate or arsenate/arsenite either slowed the rate of green rust transformation to magnetite or completely inhibited it $[62,134]$, consistent with the stabilization of green rusts by the sorption of organic and inorganic ligands $[41,58,59,135-138]$. In contrast to these abiotic systems, green rust has not been observed as an intermediate phase during magnetite formation as a secondary mineral of the bioreduction of Fe(III) oxides. In our study, either green rust or magnetite formed; there was never the co-occurrence of the phases, even in the lepidocrocite system containing $75 \mu \mathrm{M}$ phosphate, where one replicate bottle formed only green rust and the other formed only magnetite.

The formation of green rust during the bioreduction of Fe(III) oxides could occur via either a reconstructive (dissolution-reprecipitation) or a solid-state/topotactic (structural rearrangement) process. Mann et al. [62] and Hansen et al. [139] proposed that green rust formation occurs via the solid-state rearrangement of ferrihydrite following the sorption of $\mathrm{Fe}^{2+}$. Solid-state transformation was also invoked for the formation of green rust during the bioreduction of ferrihydrite in the presence of phosphate, for which the sorption of phosphate to ferrihydrite was proposed to inhibit magnetite formation [17,40]. However, the morphological differences between the nanoparticulate ferrihydrite and the micron-sized green rust crystals are not consistent with a purely topotactic or pseudomorphic process for ferrihydrite transformation to green rust, and a similar argument can be made for the transformations of akaganeite, feroxyhyte, and lepidocrocite. During the bioreduction of lepidocrocite in the presence of phosphate, $\mathrm{O}^{\prime}$ Loughlin et al. [66] reported a progressive transition in particle morphology from lepidocrocite to green rust, consistent with an initial structural reorganization of lepidocrocite to proto green rust particles that then grow to achieve the characteristic platy, hexagonal morphology of typical green rust. The formation of green rust during the bioreduction of akaganeite, ferrihydrite, and feroxyhyte might proceed by a similar process involving the sorption of phosphate or other ligands.

As satisfying as it would be to propose a consistent model for the mechanism of green rust formation during $\mathrm{Fe}(\mathrm{III})$ oxide bioreduction, such an understanding remains elusive. Moreover, the conflicting and often contradictory data suggest that there are perhaps multiple pathways to green rust formation.

\subsection{Environmental Relevance}

Dynamic redox conditions are ubiquitous in aquatic and terrestrial systems across all geographic zones (polar, temperate, and tropical) and are evident in a diverse range of environments, including stratified lakes, lacustrine and marine sediments, floodplains and wetland environments, groundwater-surface water interaction zones, and many others. Throughout these varied environments, the activity of Fe(III)-reducing microbes is coupled with several major ecosystem processes, including the mineralization of organic matter and accompanying the release of $\mathrm{CO}_{2}$, the uptake and release of nutrients (e.g., $\mathrm{N}$ and $\mathrm{P}$ ), and the mobility and transformations of contaminants. Moreover, it is largely due to microbially-driven $\mathrm{Fe}(\mathrm{III})$ reduction that $\mathrm{Fe}(\mathrm{II})$ is typically one of the most abundant reductants in aquatic and terrestrial environments under suboxic and anoxic conditions [140-142]. However, the reactivity of Fe(II) is highly dependent on its chemical speciation [143-147], so insights into the factors that influence the formation of specific Fe(II) phases has important implications for understanding Fe biogeochemistry and contaminant and nutrient transformations in natural and engineered environments. Among the $\mathrm{Fe}(\mathrm{II})$-bearing secondary minerals resulting from microbial reduction of $\mathrm{Fe}(\mathrm{III})$ oxides, green rusts are particularly effective reductants for a wide range of contaminants of concern, including nitrate, chlorinated solvents, nitroaromatics, azo dyes, toxic metals, metallolids, and radionuclides $[86,143,144,148-168]$. Therefore, identifying the factors that lead to the 
formation of green rusts and other reactive $\mathrm{Fe}(\mathrm{II})$ phases can contribute to better water quality management in natural and engineered environments.

Author Contributions: Conceptualization, E.J.O.; formal analysis, C.A.G. and E.J.O.; funding acquisition, M.I.B., K.M.K., E.J.O. and M.M.S.; investigation, M.I.B., C.A.G., K.M.K., E.J.O. and M.M.S.; project administration, E.J.O.; writing—original draft, E.J.O.; writing—review and editing, M.I.B., C.A.G., K.M.K., E.J.O. and M.M.S. All authors have read and agreed to the published version of the manuscript.

Funding: Research under the Wetlands Hydrobiogeochemistry Scientific Focus Area (SFA) at Argonne National Laboratory was supported by the Subsurface Biogeochemical Research Program, Office of Biological and Environmental Research (BER), Office of Science, U.S. Department of Energy (DOE), under contract DE-AC02- 06CH11357.

Data Availability Statement: Data available on request.

Acknowledgments: We thank Russell Cook for his assistance with SEM imaging; Michael McCormick for B.E.T. surface area measurements of the Fe(III) oxides; Drew Latta for providing ferric green rust; and the three anonymous reviewers for their thoughtful comments.

Conflicts of Interest: The authors declare no conflict of interest. The funders had no role in the design of the study; in the collection, analyses, or interpretation of data; in the writing of the manuscript, or in the decision to publish the results.

\section{References}

1. Roden, E.E.; Lovley, D.R. Dissimilatory Fe(III) reduction by the marine microorganism Desulfuromonas acetoxidans. Appl. Environ. Microbiol. 1993, 59, 734-742. [CrossRef]

2. Caccavo, F., Jr;; Coates, J.D.; Rossello-Mora, R.A.; Ludwig, W.; Schleifer, K.H.; Lovley, D.R.; McInerney, M.J. Geovibrio ferrireducens, a phylogenetically distinct dissimilatory Fe(III)-reducing bacterium. Arch. Microbiol. 1996, 165, 370-376. [CrossRef] [PubMed]

3. Coates, J.D.; Bhupathiraju, V.K.; Achenbach, L.; McInerney, M.J.; Lovley, D.R. Geobacter hydrogenophilus, Geobacter chapelli and Geobacter grbiciae, three new, strictly anaerobic, dissimilatory Fe(III)-reducers. Int. J. Syst. Evolut. Microbiol. 2001, 51, 581-588. [CrossRef]

4. Coates, J.D.; Ellis, D.J.; Gaw, C.V.; Lovley, D.R. Geothrix fermentans gen. nov., sp. nov., a novel Fe(III)-reducing bacterium from a hydrocarbon-contaminated aquifer. Int. J. Syst. Bacteriol. 1999, 49, 1615-1622. [CrossRef] [PubMed]

5. Dong, Y.; Sanford, R.A.; Boyanov, M.I.; Kemner, K.M.; Flynn, T.M.; O’Loughlin, E.J.; Chang, Y.J.; Locke, R.A., Jr;; Weber, J.R.; Egan, S.M.; et al. Orenia metallireducens sp. nov. strain Z6, a novel metal-reducing member of the phylum firmicutes from the deep subsurface. Appl. Environ. Microbiol. 2016, 82, 6440-6453. [CrossRef] [PubMed]

6. Dong, Y.; Sanford, R.A.; Boyanov, M.I; Kemner, K.M.; Flynn, T.M.; O'Loughlin, E.J.; Locke Ii, R.A.; Weber, J.R.; Egan, S.M.; Fouke, B.W. Tepidibacillus decaturensis sp. nov.: A microaerophilic, moderately thermophilic iron-reducing bacterium isolated from a depth of $1.7 \mathrm{~km}$ in the Illinois Basin, USA. Int. J. Syst. Evol. Microbiol. 2016. [CrossRef]

7. Ettwig, K.F.; Zhu, B.; Speth, D.; Keltjens, J.T.; Jetten, M.S.; Kartal, B. Archaea catalyze iron-dependent anaerobic oxidation of methane. Proc. Natl. Acad. Sci. USA 2016. [CrossRef]

8. Kashefi, K.; Lovley, D.R. Reduction of Fe(III), $\mathrm{Mn}(\mathrm{IV})$, and toxic metals at $100^{\circ} \mathrm{C}$ by Pyrobacterium islandicum. Appl. Environ. Microbiol. 2000, 66, 1050-1056. [CrossRef]

9. Sanford, R.A.; Cole, J.R.; Tiedje, J.M. Characterization and description of Anaeromyxobacter dehalogens gen. nov., sp. nov., an Aryl-halorespiring facultative anaerobic myxobacterium. Appl. Environ. Microbiol. 2002, 68, 893-900. [CrossRef]

10. Roh, Y.; Liu, S.V.; Li, G.; Huang, H.; Phelps, T.J.; Zhou, J. Isolation and characterization of metal-reducing Thermoanaerobacter strains from deep subsurface environments of the Piceance Basin, Colorado. Appl. Environ. Microbiol. 2002, 68, 6013-6020. [CrossRef]

11. Lovley, D.R.; Giovanoli, S.J.; White, D.C.; Champine, J.E.; Phillips, E.J.P.; Gorby, Y.A.; Goodwin, S. Geobacter metallireducens gen. nov. sp. nov., a microorganism capable of coupling the complete oxidation of organic compounds to the reduction of iron and other metals. Arch. Microbiol. 1993, 159, 336-344. [CrossRef] [PubMed]

12. O'Loughlin, E.J.; Larese-Casanova, P.; Scherer, M.M.; Cook, R.E. Green rust formation from the bioreduction of g-FeOOH (lepidocrocite): Comparison of several Shewanella species. Geomicrobiol. J. 2007, 24, 211-230.

13. Slobodkin, A.; Reysenbach, A.L.; Strutz, N.; Dreier, M.; Wiegel, J. Thermoterrabacterium ferrireducens gen. nov., sp. nov., a thermophilic anaerobic dissimilatory Fe(III)-reducing bacterium from a continental hot spring. Int. J. Syst. Bacteriol. 1997, 47, 541-547. [CrossRef] [PubMed]

14. Greene, A.C.; Patel, B.K.; Sheehy, A.J. Deferribacter thermophilus gen. nov., sp. nov., a novel thermophilic manganese- and iron-reducing bacterium isolated from a petroleum reservoir. Int. J. Syst. Bacteriol. 1997, 47, 505-509. [CrossRef]

15. Roh, Y.; Chon, C.-M.; Moon, J.-W. Metal reduction and biomineralization by an alkaliphilic metal-reducing bacterium, Alkaliphilus metalliredigens (QYMF). Geosci. J. 2007, 11, 415-423. [CrossRef] 
16. Lovley, D.R.; Stolz, J.F.; Nord, G.L., Jr.; Phillips, E.J.P. Anaerobic production of magnetite by a dissimilatory iron-reducing microorganism. Nature 1987, 330, 252-254. [CrossRef]

17. Fredrickson, J.K.; Zachara, J.M.; Kennedy, D.W.; Dong, H.; Onstott, T.C.; Hinman, N.W.; Li, S.-M. Biogenic iron mineralization accompanying the dissimilatory reduction of hydrous ferric oxide by a groundwater bacterium. Geochim. Cosmochim. Acta 1998, 62, 3239-3257. [CrossRef]

18. Ona-Nguema, G.; Abdelmoula, M.; Jorand, F.; Benali, O.; Géhin, A.; Block, J.-C.; Génin, J.-M.R. Iron(II,III) hydroxycarbonate green rust formation and stabilization from lepidocrocite bioreduction. Environ. Sci. Technol. 2002, 36, 16-20. [CrossRef]

19. Glasauer, S.; Weidler, P.G.; Langley, S.; Beveridge, T.J. Controls on Fe reduction and mineral formation by a subsurface bacterium. Geochim. Cosmochim. Acta 2003, 67, 1277-1288. [CrossRef]

20. Roh, Y.; Zhang, C.-L.; Vali, H.; Lauf, R.J.; Zhou, J.; Phelps, T.J. Biogeochemical and environmental factors in Fe biomineralization: Magnetite and siderite formation. Clays Clay Miner. 2003, 51, 83-95. [CrossRef]

21. Kukkadapu, R.K.; Zachara, J.M.; Fredrickson, J.K.; Kennedy, D.W.; Dohnalkova, A.C.; Mccready, D.E. Ferrous hydroxy carbonate is a stable transformation product of biogenic magnetite. Am. Mineral. 2005, 90, 510-515. [CrossRef]

22. Behrends, T.; Van Cappellen, P. Transformation of hematite into magnetite during dissimilatory iron reduction-conditions and mechanisms. Geomicrobiol. J. 2007, 24, 403-416. [CrossRef]

23. Boyanov, M.I.; O'Loughlin, E.J.; Kemner, K.M. Iron phase transformations resulting from the respiration of Shewanella putrefaciens on a mixed mineral phase. J. Phys. Conf. Ser. 2009, 190, 1-4. [CrossRef]

24. Shelobolina, E.; Konishi, H.; Xu, H.; Benzine, J.; Xiong, M.Y.; Wu, T.; Blothe, M.; Roden, E. Isolation of phyllosilicate-iron redox cycling microorganisms from an illite-smectite rich hydromorphic soil. Front. Microbiol. 2012, 3, 134. [CrossRef]

25. Dong, Y.; Sanford, R.A.; Boyanov, M.I.; Flynn, T.M.; O’Loughlin, E.J.; Kemner, K.M.; George, S.; Fouke, K.E.; Li, S.; Huang, D.; et al. Controls on iron reduction and biomineralization over broad environmental conditions as suggested by the Firmicutes Orenia metallireducens strain Z6. Environ. Sci. Technol. 2020, 54, 10128-10140. [CrossRef] [PubMed]

26. Cutting, R.S.; Coker, V.S.; Fellowes, J.W.; Lloyd, J.R.; Vaughan, D.J. Mineralogical and morphological constraints on the reduction of Fe(III) minerals by Geobacter sulfurreducens. Geochim. Cosmochim. Acta 2009, 73, 4004-4022. [CrossRef]

27. Zegeye, A.; Mustin, C.; Jorand, F. Bacterial and iron oxide aggregates mediate secondary iron mineral formation: Green rust versus magnetite. Geobiology 2010, 8, 209-222. [CrossRef]

28. Zachara, J.M.; Kukkadapu, R.K.; Frederickson, J.K.; Gorby, Y.A.; Smith, S.C. Biomineralization of poorly crystalline Fe(III) oxides by dissimilatory metal reducing bacteria (DMRB). Geomicrobiol. J. 2002, 19, 179-207. [CrossRef]

29. Hansel, C.M.; Benner, S.G.; Neiss, J.; Dohnalkova, A.; Kukkadapu, R.K.; Fendorf, S. Secondary mineralization pathways induced by dissimilatory iron reduction of ferrihydrite under advective flow. Geochim. Cosmochim. Acta 2003, 67, 2977-2992. [CrossRef]

30. Bae, S.; Lee, W. Biotransformation of lepidocrocite in the presence of quinones and flavins. Geochim. Cosmochim. Acta 2013, 114, 144-155. [CrossRef]

31. O'Loughlin, E.J.; Gorski, C.; Scherer, M.M.; Boyanov, M.I.; Kemner, K.M. Effects of oxyanions, natural organic matter, and cell density on the bioreduction of lepidocrocite $(\mathrm{g}-\mathrm{FeOOH})$ and secondary mineral formation. Environ. Sci. Technol. 2010, 44, 4570-4576. [CrossRef] [PubMed]

32. Zegeye, A.; Ruby, C.; Jorand, F. Kinetic and thermodynamic analysis during dissimilatory g-FeOOH reduction: Formation of green rust 1 and magnetite. Geomicrobiol. J. 2007, 24, 51-64. [CrossRef]

33. Salas, E.C.; Berelson, W.M.; Hammond, D.E.; Kampf, A.R.; Nealson, K.H. The impact of bacterial strain on the products of dissimilatory iron reduction. Geochim. Cosmochim. Acta 2010, 74, 574-583. [CrossRef] [PubMed]

34. Fredrickson, J.K.; Kota, S.; Kukkadapu, R.K.; Liu, C.; Zachara, J.M. Influence of electron donor/acceptor concentrations on hydrous ferric oxide (HFO) bioreduction. Biodegradation 2003, 14, 91-103. [CrossRef]

35. Lee, J.-H.; Roh, Y.; Kim, K.-W.; Hur, H.-G. Organic acid-dependent iron mineral formation by a newly isolated iron-reducing bacterium, Shewanella sp. HN-41. Geomicrobiol. J. 2007, 24, 31-41. [CrossRef]

36. Salas, E.C.; Berelson, W.M.; Hammond, D.E.; Kampf, A.R.; Nealson, K.H. The influence of carbon source on the products of dissimilatory iron reduction. Geomicrobiol. J. 2009, 26, 451-462. [CrossRef]

37. O'Loughlin, E.J.; Gorski, C.A.; Flynn, T.M.; Scherer, M.M. Electron donor utilization and secondary mineral formation during the bioreduction of lepidocrocite by Shewanella putrefaciens CN32. Minerals 2019, 9, 434. [CrossRef]

38. Jorand, F.; Zegeye, A.; Ghanbaja, J.; Abdelmoula, M. The formation of green rust induced by tropical river biofilm components. Sci. Total Environ. 2011, 409, 2586-2596. [CrossRef]

39. Borch, T.; Masue, Y.; Kukkadapu, R.K.; Fendorf, S. Phosphate imposed limitations on biological reduction and alteration of ferrihydrite. Environ. Sci. Technol. 2007, 41, 166-172. [CrossRef]

40. Kukkadapu, R.K.; Zachara, J.M.; Fredrickson, J.K.; Kennedy, D.W. Biotransformation of two-line silica-ferrihydrite by a dissimilatory Fe(III)-reducing bacterium: Formation of carbonate green rust in the presence of phosphate. Geochim. Cosmochim. Acta 2004, 68, 2799-2814. [CrossRef]

41. Sergent, A.-S.; Jorand, F.; Hanna, K. Effects of Si-bearing minerals on the nature of secondary iron mineral products from lepidocrocite bioreduction. Chem. Geol. 2011, 289, 86-97. [CrossRef]

42. Shi, L.; Richardson, D.J.; Wang, Z.; Kerisit, S.N.; Rosso, K.M.; Zachara, J.M.; Fredrickson, J.K. The roles of outer membrane cytochromes of Shewanella and Geobacter in extracellular electron transfer. Environ. Microbiol. Rep. 2009, 1, 220-227. [CrossRef] [PubMed] 
43. Gorby, Y.A.; Yanina, S.; McLean, J.S.; Rosso, K.M.; Moyles, D.; Dohnalkova, A.; Beveridge, T.J.; Chang, I.S.; Kim, B.H.; Kim, K.S.; et al. Electrically conductive bacterial nanowires produced by Shewanella oneidensis strain MR-1 and other microorganisms. Proc. Natl. Acad. Sci. USA 2006, 103, 11358-11363. [CrossRef] [PubMed]

44. Reguera, G.; McCarthy, K.D.; Metha, T.; Nicoll, J.S.; Tuominen, M.T.; Lovley, D.R. Extracellular electron transfer via microbial nanowires. Nature 2005, 435, 1098-1101. [CrossRef] [PubMed]

45. Lovley, D.R.; Coates, J.D.; Blunt-Harris, E.L.; Phillips, E.J.P.; Woodward, J.C. Humic-substances as electron acceptors for microbial respiration. Nature 1996, 382, 445-448. [CrossRef]

46. Nevin, K.P.; Lovley, D.R. Potential for nonenzymatic reduction of Fe(III) via electron shuttling in subsurface sediments. Environ. Sci. Technol. 2000, 34, 2472-2478. [CrossRef]

47. Royer, R.A.; Burgos, W.D.; Fisher, A.S.; Jeon, B.-H.; Unz, R.F.; Dempsey, B.A. Enhancement of hematite bioreduction by natural organic matter. Environ. Sci. Technol. 2002, 36, 2897-2904. [CrossRef]

48. Jiang, J.; Kappler, A. Kinetics of microbial and chemical reduction of humic substances: Implications for electron shuttling. Environ. Sci. Technol. 2008, 42, 3563-3569. [CrossRef]

49. Wolf, M.; Kappler, A.; Jiang, J.; Meckenstock, R.U. Effects of humic substances at low concentrations on ferrihydrite reduction by Geobacter metallireducens. Environ. Sci. Technol. 2009, 43, 5679-5685. [CrossRef]

50. Roden, E.E.; Kappler, A.; Bauer, I.; Jiang, J.; Paul, A.; Stoesser, R.; Konishi, H.; Xu, H. Extracellular electron transfer through microbial reduction of solid-phase humic substances. Nat. Geosci. 2010, 3, 417-421. [CrossRef]

51. Scott, D.T.; McKnight, D.M.; Blunt-Harris, E.L.; Kolesar, S.E.; Lovley, D.R. Quinone moieties act as electron acceptors in the reduction of humic substances by humics-reducing microorganisms. Environ. Sci. Technol. 1998, 32, 2984-2989. [CrossRef]

52. Klapper, L.; McKnight, D.M.; Fulton, J.R.; Blunt-Harris, E.L.; Nevin, K.P.; Lovley, D.R.; Hatcher, P.G. Fulvic acid oxidation state detection using fluorescence spectroscopy. Environ. Sci. Technol. 2002, 36, 3170-3175. [CrossRef] [PubMed]

53. Nurmi, J.T.; Tratnyek, P.G. Electrochemical properties of natural organic matter (NOM), fractions of NOM, and model biogeochemical electron shuttles. Environ. Sci. Technol. 2002, 36, 617-624. [CrossRef] [PubMed]

54. Tratnyek, P.G.; Macalady, D.L. Abiotic reductions of nitro aromatic pesticides in anaerobic laboratory systems. J. Agric. Food Chem. 1989, 37, 248-254. [CrossRef]

55. O'Loughlin, E.J. Effects of electron transfer mediators on the biodegradation of lepidocrocite (g-FeOOH) by Shewanella putrefaciens CN32. Environ. Sci. Technol. 2008, 42, 6876-6882. [CrossRef]

56. Smeck, N.E. Phosphorous dynamics in soils and landscapes. Geoderma 1985, 36, 185-199. [CrossRef]

57. Torrent, J. Interactions between phosphate and iron oxide. Adv. GeoEcol. 1997, 30, 321-344.

58. Benali, O.; Abdelmoula, M.; Refait, P.; Génin, J.-M.R. Effect of orthophosphate on the oxidation products of Fe(II)-Fe(III) hydroxycarbonate: The transformation of green rust to ferrihydrite. Geochim. Cosmochim. Acta 2001, 65, 1715-1726. [CrossRef]

59. Bocher, F.; Géhin, A.; Ruby, C.; Ghanbaja, J.; Abdelmoula, M.; Génin, J.-M.R. Coprecipitation of Fe(II-III) hydroxycarbonate green rust stabilized by phosphate adsorption. Solid State Sci. 2004, 6, 117-124. [CrossRef]

60. Cumplido, J.; Barrón, V.; Torrent, J. Effect of phosphate on the formation of nanophase lepidocrocite from Fe(II) sulfate. Clays Clay Miner. 2000, 48, 503-510. [CrossRef]

61. Gálvez, N.; Barrón, V.; Torrent, J. Effect of phosphate on the crystallization of hematite, goethite, and lepidocrocite from ferrihydrite. Clays Clay Miner. 1999, 47, 304-311. [CrossRef]

62. Mann, S.; Sparks, N.H.C.; Coouling, S.B.; Larcombe, M.C.; Frankel, R.B. Crystallochemical characterization of magnetic spinels prepared from aqueous solution. J. Chem. Soc. Faraday Trans. 1989, 85, 3033-3044. [CrossRef]

63. Refait, P.; Reffass, M.; Landoulsi, J.; Sabot, R.; Jeannin, M. Role of phosphate species during the formation and transformation of Fe(II-III) hydroxycarbonate green rust. Colloids Surf. A 2007, 299, 29-37. [CrossRef]

64. Zachara, J.M.; Kukkadapu, R.K.; Peretyazhko, T.; Bowden, M.; Wang, C.; Kennedy, D.W.; Moore, D.; Arey, B. The mineralogic transformation of ferrihydrite induced by heterogeneous reaction with bioreduced anthraquinone disulfonate (AQDS) and the role of phosphate. Geochim. Cosmochim. Acta 2011, 75, 6330-6349. [CrossRef]

65. Borch, T.; Fendorf, S. Phosphate interactions with iron (hydr)oxides: Mineralization pathways and phosphorous retention upon bioreduction. In Adsorption of Metals by Geomedia II Variables, Mechanisms, and Model Applications; Barnett, M.O., Kent, D., Eds.; Elsevier: New York, NY, USA, 2008; Volume 7, pp. 321-348.

66. O'Loughlin, E.J.; Boyanov, M.I.; Flynn, T.M.; Gorski, C.; Hofmann, S.M.; McCormick, M.L.; Scherer, M.M.; Kemner, K.M. Effects of bound phosphate on the bioreduction of lepidocrocite $(\mathrm{g}-\mathrm{FeOOH})$ and maghemite $\left(\mathrm{g}-\mathrm{Fe}_{2} \mathrm{O}_{3}\right)$ and formation of secondary minerals. Environ. Sci. Technol. 2013, 47, 9157-9166. [CrossRef] [PubMed]

67. O'Loughlin, E.J.; Gorski, C.A.; Scherer, M.M. Effects of phosphate on secondary mineral formation during the bioreduction of akaganeite (b-FeOOH): Green rust versus framboidal magnetite. Curr. Inorg. Chem. 2015, 5, 214-224. [CrossRef]

68. Christiansen, B.C.; Balic-Zunic, T.; Dideriksen, K.; Stipp, S.L.S. Identification of green rust in groundwater. Environ. Sci. Technol. 2009, 43, 3436-3441. [CrossRef]

69. Johnson, C.A.; Freyer, G.; Fabisch, M.; Caraballo, M.A.; Küsel, K.; Hochella, M.F. Observations and assessment of iron oxide and green rust nanoparticles in metal-polluted mine drainage within a steep redox gradient. Environ. Chem. 2014, 11, 377. [CrossRef]

70. Zegeye, A.; Bonneville, S.; Benning, L.G.; Sturm, A.; Fowle, D.A.; Jones, C.; Canfield, D.E.; Ruby, C.; MacLean, L.C.; Nomosatryo, S.; et al. Green rust formation controls nutrient availability in a ferruginous water column. Geology 2012, 40, 599-602. [CrossRef] 
71. Feder, F.; Trolard, F.; Klingelhöfer, G.; Bourrié, G. In situ Mössbauer spectroscopy: Evidence for green rust (fougerite) in a gleysol and its mineralogical transformations with time and depth. Geochim. Cosmochim. Acta 2005, 69, 4463-4483. [CrossRef]

72. Génin, J.-M.R.; Bourrié, G.; Trolard, F.; Abdelmoula, M.; Jaffrezic, A.; Refait, P.; Maitre, V.; Humbert, B.; Herbillon, A. Thermodynamic equilibria in aqueous suspensions of synthetic and natural Fe(II)-Fe(III) green rusts: Occurrences of the mineral in hydromorphic soils. Environ. Sci. Technol. 1998, 32, 1058-1068. [CrossRef]

73. Refait, P.; Abdelmoula, M.; Trolard, F.; Génin, J.-M.R.; Ehrhardt, J.J.; Bourrié, G. Mössbauer and XAS study of a green rust mineral: The partial substitution of $\mathrm{Fe}^{2+}$ by $\mathrm{Mg}^{2+}$. Am. Mineral. 2001, 86, 731-739. [CrossRef]

74. Trolard, F.; Génin, J.-M.R.; Abdelmoula, M.; Bourrié, G.; Humbert, B.; Herbillon, A. Identification of a green rust mineral in a reductomorphic soil by Mössbauer and Raman spectroscopies. Geochim. Cosmochim. Acta 1997, 61, 1107-1111. [CrossRef]

75. Weatherington-Rice, J.; Bigham, J.M. Buried pre-Illinoian-age lacustrine deposits with "green rust" colors in Clermont County, Ohio. Ohio J. Sci. 2006, 106, 35-44.

76. Latta, D.E.; Boyanov, M.I.; Kemner, K.M.; O'Loughlin, E.J.; Scherer, M.M. Abiotic reduction of uranium by Fe(II) in soil. Appl. Geochem. 2012, 27, 1512-1524. [CrossRef]

77. Bearcock, J.M.; Perkins, W.T.; Dinelli, E.; Wade, S.C. Fe(II)/Fe(III) 'green rust' developed within ocherous coal mine drainage sediment in South Wales, UK. Mineral. Mag. 2006, 70, 731-741. [CrossRef]

78. Bender Koch, C.; Mørup, S. Identification of green rust in an ochre sludge. Clay Miner. 1991, 26, 577-582. [CrossRef]

79. Root, R.A.; Dixit, S.; Campbell, K.M.; Jew, A.D.; Hering, J.G.; O’Day, P.A. Arsenic sequestration by sorption processes in high-iron sediments. Geochim. Cosmochim. Acta 2007, 71, 5782-5803. [CrossRef]

80. Trolard, F.; Bourrié, G.; Abdelmoula, M.; Refait, P.; Feder, F. Fougerite, a new mineral of the pyroaurite-iowaite group: Description and crystal structure. Clays Clay Miner. 2007, 55, 323-334. [CrossRef]

81. Mills, S.J.; Christy, A.G.; Génin, J.M.R.; Kameda, T.; Colombo, F. Nomenclature of the hydrotalcite supergroup: Natural layered double hydroxides. Mineral. Mag. 2012, 76, 1289-1336. [CrossRef]

82. Génin, J.M.R.; Mills, S.J.; Christy, A.G.; Guérin, O.; Herbillon, A.J.; Kuzmann, E.; Ona-Nguema, G.; Ruby, C.; Upadhyay, C. Mössbauerite, $\mathrm{Fe}_{6}{ }^{3+} \mathrm{O}_{4}(\mathrm{OH})_{8}\left[\mathrm{CO}_{3}\right] \cdot 3 \mathrm{H}_{2} \mathrm{O}$, the fully oxidized 'green rust' mineral from Mont Saint-Michel Bay, France. Mineral. Mag. 2014, 78, 447-465. [CrossRef]

83. Duval, S.; Baymann, F.; Schoepp-Cothenet, B.; Trolard, F.; Bourrié, G.; Grauby, O.; Branscomb, E.; Russell, M.J.; Nitschke, W. Fougerite: The not so simple progenitor of the first cells. Interface Focus 2019, 9. [CrossRef] [PubMed]

84. Zachara, J.M.; Fredrickson, J.K.; Li, S.-M.; Kennedy, D.W.; Smith, S.C.; Gassman, P.L. Bacterial reduction of crystalline Fe ${ }^{3+}$ oxides in single phase suspension and subsurface materials. Am. Mineral. 1998, 83, 1426-1443. [CrossRef]

85. Schwertmann, U.; Cornell, R.M. Iron Oxides in the Laboratory, 2nd ed.; Wiley-VCH: Weinheim, Germany, $2000 ;$ p. 188.

86. Latta, D.E.; Boyanov, M.I.; Kemner, K.M.; O'Loughlin, E.J.; Scherer, M.M. Reaction of uranium(VI) with green rusts: Effect of interlayer anion. Curr. Inorg. Chem. 2015, 5, 156-168. [CrossRef]

87. Stookey, L.L. Ferrozine-A new spectrophotometric reagent for iron. Anal. Chem. 1970, 42, 779-781. [CrossRef]

88. Sørensen, J. Reduction of ferric iron in anaerobic, marine sediment and interaction with reduction of nitrate and sulfate. Appl. Environ. Microbiol. 1982, 43, 319-324. [CrossRef] [PubMed]

89. Hansel, C.M.; Benner, S.G.; Nico, P.; Fendorf, S. Structural constraints of ferric (hydr)oxides on dissimilatory iron reduction. Geochim. Cosmochim. Acta 2004, 68, 3217-3229. [CrossRef]

90. Roden, E.E. Geochemical and microbiological controls on dissimilatory iron reduction. Comptes Rendus Geosci. 2006, 338, 456-467. [CrossRef]

91. Bonneville, S.; Behrends, T.; Van Cappellen, P. Solubility and dissimilatory reduction kinetics of iron(III) oxyhydroxides: A linear free energy relationship. Geochim. Cosmochim. Acta 2009, 73, 5273-5282. [CrossRef]

92. Dong, H.; Fredrickson, J.K.; Kennedy, D.W.; Zachara, J.M.; Kukkadapu, R.K.; Onstott, T.C. Mineral transformation associated with the microbial reduction of magnetite. Chem. Geol. 2000, 169, 299-318. [CrossRef]

93. Liu, C.; Kota, S.; Zachara, J.M.; Fredrickson, J.K.; Brinkman, C.K. Kinetic analysis of the bacterial reduction of goethite. Environ. Sci. Technol. 2001, 35, 2482-2490. [CrossRef] [PubMed]

94. Zachara, J.M.; Fredrickson, J.K.; Smith, S.C.; Glassman, P.L. Solubilization of Fe(III) oxide-bound trace metals by a dissimilatory Fe(III) reducing bacterium. Geochim. Cosmochim. Acta 2001, 65, 75-93. [CrossRef]

95. Yan, B.; Wrenn, B.A.; Basak, S.; Biswas, P.; Giammar, D.E. Microbial reduction of Fe(III) in hematite nanoparticles by Geobacter sulfurreducens. Environ. Sci. Technol. 2008, 42, 6526-6531. [CrossRef] [PubMed]

96. Luo, H.-W.; Zhang, X.; Chen, J.-J.; Yu, H.-Q.; Sheng, G.-P. Probing the biotransformation of hematite nanoparticles and magnetite formation mediated by Shewanella oneidensis MR-1 at the molecular scale. Environ. Sci. Nano 2017, 4, 2395-2404. [CrossRef]

97. Cooper, D.C.; Picardal, F.; Rivera, J.; Talbot, C. Zinc immobilization and magnetite formation via ferric oxide reduction by Shewanella putrefaciens 200. Environ. Sci. Technol. 2000, 34, 100-106. [CrossRef]

98. Liu, D.; Wang, H.; Dong, H.; Qiu, X.; Dong, X.; Cravotta, C.A., III. Mineral transformations associated with goethite reduction by Methanosarcina barkeri. Chem. Geol. 2011, 288, 53-60. [CrossRef]

99. Gorski, C.A.; Scherer, M.M. Determination of nanoparticulate magnetite stoichiometry by Mössbauer spectroscopy, acidic dissolution, and powder X-ray diffraction: A critical review. Am. Mineral. 2010, 95, 1017-1026. [CrossRef]

100. Li, Y.L.; Pfiffner, S.M.; Dyar, M.D.; Vali, H.; Konhauser, K.; Cole, D.R.; Rondinone, A.J.; Phelps, T.J. Degeneration of biogenic superparamagnetic magnetite. Geobiology 2009, 7, 25-34. [CrossRef] 
101. Jorand, F.; Zegeye, A.; Landry, F.; Ruby, C. Reduction of ferric green rust by Shewanella putrefaciens. Lett. Appl. Microbiol. 2007, 45, 515-521. [CrossRef]

102. Peretyazhko, T.S.; Zachara, J.M.; Kennedy, D.W.; Fredrickson, J.K.; Arey, B.W.; McKinley, J.P.; Wang, C.M.; Dohnalkova, A.C.; Xia, Y. Ferrous phosphate surface precipitates resulting from the reduction of intragrain 6-line ferrihydrite by Shewanella oneidensis MR-1. Geochim. Cosmochim. Acta 2010, 74, 3751-3767. [CrossRef]

103. Zegeye, A.; Abdelmoula, M.; Usman, M.; Hanna, K.; Ruby, C. In situ monitoring of lepidocrocite bioreduction and magnetite formation by reflection Mössbauer spectroscopy. Am. Mineral. 2011, 96, 1410-1413. [CrossRef]

104. Jorand, F.P.A.; Sergent, A.S.; Remy, P.P.; Bihannic, I.; Ghanbaja, J.; Lartiges, B.; Hanna, K.; Zegeye, A. Contribution of anionic vs. neutral polymers to the formation of green rust 1 from $\gamma$-FeOOH bioreduction. Geomicrobiol. J. 2013, 30, 600-615. [CrossRef]

105. Roden, E.E. Fe(III) oxide reactivity toward biological versus chemical reduction. Environ. Sci. Technol. 2003, 37, 1319-1324. [CrossRef]

106. Dominik, P.; Kaupenjohann, M. Reduction of Fe(III) (hydr)oxides with known thermodynamic stability by Geobacter metallireducens. Geomicrobiol. J. 2004, 21, 287-295. [CrossRef]

107. Azoulay, I.; Rémazeilles, C.; Refait, P. Determination of standard Gibbs free energy of formation of chukanovite and Pourbaix diagrams of iron in carbonated media. Corros. Sci. 2012, 58, 229-236. [CrossRef]

108. Ona-Nguema, G.; Morin, G.; Wang, Y.; Menguy, N.; Juillot, F.; Olovi, L.; Aquilanti, G.; Abdelmoula, M.; Ruby, C.; Bargar, J.R.; et al. Arsenite sequestration at the surface of nano- $\mathrm{Fe}(\mathrm{OH})_{2}$, ferrous-carbonate hydroxide, and green-rust after bioreduction of arsenic-sorbed lepidocrocite by Shewanella putrefaciens. Geochim. Cosmochim. Acta 2009, 73, 1359-1381. [CrossRef]

109. Williams, A.G.B.; Gregory, K.B.; Parkin, G.F.; Scherer, M.M. Hexahydro-1,3,5-trinitro-1,3,5-triazine transformation by biologically reduced ferrihydrite: Evolution of Fe mineralogy, surface area, and reaction rates. Environ. Sci. Technol. 2005, 39, 5183-5189. [CrossRef]

110. Wu, W.; Li, B.; Hu, J.; Li, J.; Wang, F.; Pan, Y. Iron reduction and magnetite biomineralization mediated by a deep-sea iron-reducing bacterium Shewanella piezotolerans WP3. J. Geophys. Res. 2011, 116. [CrossRef]

111. Amstaetter, K.; Borch, T.; Kappler, A. Influence of humic acid imposed changes of ferrihydrite aggregation on microbial Fe(III) reduction. Geochim. Cosmochim. Acta 2012, 85, 326-341. [CrossRef]

112. Han, R.; Liu, T.; Li, F.; Li, X.; Chen, D.; Wu, Y. Dependence of secondary mineral formation on Fe(II) production from ferrihydrite reduction by Shewanella oneidensis MR-1. ACS Earth Space Chem. 2018, 2, 399-409. [CrossRef]

113. Perez-Gonzalez, T.; Jimenez-Lopez, C.; Neal, A.L.; Rull-Perez, F.; Rodriguez-Navarro, A.; Fernandez-Vivas, A.; Iañez-Pareja, E. Magnetite biomineralization induced by Shewanella oneidensis. Geochim. Cosmochim. Acta 2010, 74, 967-979. [CrossRef]

114. Vali, H.; Weiss, B.; Li, Y.-L.; Sears, S.K.; Kim, S.S.; Kirschvink, J.L.; Zhang, C.L. Formation of tabular single-domain magnetite induced by Geobacter metallireducens GS-15. Proc. Natl. Acad. Sci. USA 2004, 101, 16121-16126. [CrossRef] [PubMed]

115. Bond, D.R.; Lovley, D.R. Reduction of Fe(III) oxide by methanogens in the presence and absence of extracellular quinones. Environ. Microbiol. 2002, 4, 115-124. [CrossRef] [PubMed]

116. Straub, K.L.; Schink, B. Evaluation of electron-shuttling compounds in microbial ferric iron reduction. FEMS Microbiol. Lett. 2003, 220, 229-233. [CrossRef]

117. Coker, V.S.; Bell, A.M.T.; Pearce, C.I.; Pattrick, R.A.D.; van der Laan, G.; Lloyd, J.R. Time-resolved synchrotron powder x-ray diffraction study of magnetite formation by the Fe(III)-reducing bacterium Geobacter sulfurreducens. Am. Mineral. 2008, 93, 540-547. [CrossRef]

118. Jung, J.; Bae, S.; Lee, W. Indirect contact of bio-transformation of lepidocrocite: Role of electron transfer mediator. Sustain. Environ. Res. 2012, 23, 193-198.

119. Cornell, R.M.; Schwertmann, U. The Iron Oxides: Structure, Properties, Reactions, Occurrence and Uses, 2nd ed.; Wiley-VCH: New York, NY, USA, 2003; p. 664.

120. Biber, M.; dos Santos Afonso, M.; Stumm, W. The coordination chemistry of weathering: IV. Inhibition of the dissolution of oxide minerals. Geochim. Cosmochim. Acta 1994, 58, 1999-2010. [CrossRef]

121. Liu, C.; Zachara, J.M.; Foster, N.S.; Strickland, J. Kinetics of reductive dissolution of hematite by bioreduced anthraquinone-2,6disulfonate. Environ. Sci. Technol. 2007, 41, 7730-7735. [CrossRef]

122. Parmar, N.; Gorby, Y.A.; Beveridge, T.J.; Ferris, F.G. Formation of green rust and immobilization of nickel in response to bacterial reduction of hydrous ferric oxide. Geomicrobiol. J. 2001, 18, 375-385. [CrossRef]

123. Zegeye, A.; Ona-Nguema, G.; Carteret, C.; Huguet, L.; Abdelmoula, M.; Jorand, F. Formation of hydroxysulfate green rust 2 as a single iron(II-III) mineral in microbial culture. Geomicrobiol. J. 2005, 22, 389-399. [CrossRef]

124. Etique, M.; Jorand, F.P.; Ruby, C. Magnetite as a precursor for green rust through the hydrogenotrophic activity of the iron-reducing bacteria Shewanella putrefaciens. Geobiology 2016, 14, 237-254. [CrossRef] [PubMed]

125. Ona-Nguema, G.; Jorand, F.; Benali, O.; Abdelmoula, M.; Génin, J.-M.R.; Block, J.-C. Key Role of the Kinetics of g-FeOOH Bioreduction on the Formation of Fe(II-III) Minerals, Proceedings of the Hyperfine Interactions (C): Proceedings of the International Conference on the Applications of the Mössbauer Effect (ICAME 2001), Oxford, UK, 2-7 September 2001; Thomas, M.F., Williams, J.M., Gibb, T.C., Eds.; Kluwer Academic Publishers: Dordrecht, The Netherlands, 2002; pp. 415-418.

126. Shimizu, M.; Zhou, J.; Schroder, C.; Obst, M.; Kappler, A.; Borch, T. Dissimilatory reduction and transformation of ferrihydritehumic acid coprecipitates. Environ. Sci. Technol. 2013, 47, 13375-13384. [CrossRef] [PubMed] 
127. Schoepfer, V.A.; Burton, E.D.; Johnston, S.G.; Kraal, P. Phosphate loading alters schwertmannite transformation rates and pathways during microbial reduction. Sci. Total Environ. 2019, 657, 770-780. [CrossRef] [PubMed]

128. Usman, M.; Hanna, K.; Abdelmoula, M.; Zegeye, A.; Faure, P.; Ruby, C. Formation of green rust via mineralogical transformation of ferric oxides (ferrihydrite, goethite and hematite). Appl. Clay Sci. 2012, 64, 38-43. [CrossRef]

129. Neal, A.L.; Bank, T.L.; Hochella, M.F., Jr.; Rosso, K.M. Cell adhesion of Shewanella oneidensis to iron oxide minerals: Effect of different crystal faces. Geochem. Trans. 2005, 6, 77-84. [CrossRef]

130. Parikh, S.J.; Chorover, J. ATR-FTIR spectroscopy reveals bond formation during bacterial adhesion to iron oxide. Langmuir 2006, 22, 8492-8500. [CrossRef]

131. Tamaura, Y.; Yoshida, T.; Katsura, T. The synthesis of green rust $\mathrm{II}\left(\mathrm{Fe}^{\mathrm{III} 1}-\mathrm{Fe}^{\mathrm{II} 2}\right)$ and its spontaneous transformation into $\mathrm{Fe}_{3} \mathrm{O}_{4}$. Bull. Chem. Soc. Jpn. 1984, 57, 2411-2416. [CrossRef]

132. Sumoondur, A.; Shaw, S.; Ahmed, I.; Benning, L.G. Green rust as a precursor for magnetite: An in situ synchrotron study. Mineral. Mag. 2008, 71, 201-204. [CrossRef]

133. Li, Y.-L.; Zhu, S.-Y.; Deng, K. Mössbauer hyperfine parameters of iron species in the course of Geobacter-mediated magnetite mineralization. Phys. Chem. Miner. 2011, 38, 701-708. [CrossRef]

134. Wang, Y.; Morin, G.; Ona-Nguema, G.; Brown, G.E., Jr. Arsenic(III) and arsenic(V) speciation during transformation of lepidocrocite to magnetite. Environ. Sci. Technol. 2014, 48, 14282-14290. [CrossRef]

135. Kwon, S.-K.; Kimijima, K.i.; Kanie, K.; Suzuki, S.; Muramatsu, A.; Saito, M.; Shinoda, K.; Waseda, Y. Influence of silicate ions on the formation of goethite from green rust in aqueous solution. Corros. Sci. 2007, 49, 2946-2961. [CrossRef]

136. Ruby, C.; Géhin, A.; Aissa, R.; Ghanbaja, J.; Abdelmoula, M.; Génin, J.-M.R. Chemical stability of hydroxysulfate green rust synthesized in the presence of foreign anions: Carbonate, phosphate and silicate. Hyperfine Interact. 2006, 167, 803-807. [CrossRef]

137. Sahoo, G.; Fujieda, S.; Shinoda, K.; Suzuki, S. Influence of phosphate species on green rust I transformation and local structure and morphology of g-FeOOH. Corros. Sci. 2011, 53, 2446-2452. [CrossRef]

138. Zegeye, A.; Etique, M.; Carteret, C.; Ruby, C.; Schaaf, P.; Francius, G. Origin of the differential nanoscale reactivity of biologically and chemically formed green rust crystals investigated by chemical force spectroscopy. J. Phys. Chem. C 2014, 118, 5978-5987. [CrossRef]

139. Hansen, H.C.B.; Borggaard, O.K.; Sorensen, J. Evaluation of the free energy of formation of Fe(II)-Fe(III) hydroxide-sulphate (green rust) and its reduction of nitrite. Geochim. Cosmochim. Acta 1994, 58, 2599-2608. [CrossRef]

140. Hering, J.G.; Stumm, W. Oxidative and reductive dissolution of minerals. In Mineral-Water Interface Geochemistry; Hochella, M.F.J., White, A.F., Eds.; American Mineralogical Society: Washington, DC, USA, 1990; Volume 23, pp. 427-465.

141. Heron, G.; Christensen, T.H. Impact of sediment-bound iron on redox buffering in a landfill leachate polluted aquifer (Vejen, Denmark). Environ. Sci. Technol. 1995, 29, 187-192. [CrossRef]

142. Rügge, K.; Hofstetter, T.B.; Haderlein, S.B.; Bjerg, P.L.; Knudsen, S.; Zraunig, C.; Mosbæk, H.; Christensen, T.H. Characterization of predominant reductants in an anaerobic leachate-contaminated aquifer by nitroaromatic probe compounds. Environ. Sci. Technol. 1998, 32, 23-31. [CrossRef]

143. Elsner, M.; Schwarzenbach, R.P.; Haderlein, S.B. Reactivity of Fe(II)-bearing minerals toward reductive transformation of organic contaminants. Environ. Sci. Technol. 2004, 38, 799-807. [CrossRef]

144. Lee, W.; Batchelor, B. Reductive capacity of natural reductants. Environ. Sci. Technol. 2003, 37, 535-541. [CrossRef]

145. Scheinost, A.C.; Charlet, L. Selenite reduction by mackinawite, magnetite and siderite: XAS characterization of nanosized redox products. Environ. Sci. Technol. 2008, 42, 1984-1989. [CrossRef]

146. Scheinost, A.C.; Kirsch, R.; Banerjee, D.; Fernandez-Martinez, A.; Zaenker, H.; Funke, H.; Charlet, L. X-ray absorption and photoelectron spectroscopy investigation of selenite reduction by $\mathrm{Fe}^{\mathrm{II}}$-bearing minerals. J. Contam. Hydrol. 2008, 102, $228-245$. [CrossRef] [PubMed]

147. O'Loughlin, E.J.; Kelly, S.D.; Kemner, K.M. XAFS investigation of the interactions of UVI with secondary mineralization products from the bioreduction of Fe ${ }^{\text {III }}$ oxides. Environ. Sci. Technol. 2010, 44, 1656-1661. [CrossRef]

148. Bond, D.L.; Fendorf, S. Kinetics and structural constraints of chromate reduction by green rusts. Environ. Sci. Technol. 2003, 37, 2750-2757. [CrossRef] [PubMed]

149. Christiansen, B.C.; Geckeis, H.; Marquardt, C.M.; Bauer, A.; Römer, J.; Wiss, T.; Schild, D.; Stipp, S.L.S. Neptunyl (NpO $2^{+}$) interaction with green rust, $\mathrm{GR}_{\mathrm{Na}, \mathrm{SO} 4}$. Geochim. Cosmochim. Acta 2011, 75, 1216-1226. [CrossRef]

150. Erbs, M.; Hansen, H.C.B.; Olsen, C.E. Reductive dechlorination of carbon tetrachloride using iron(II) iron(III) hydroxide sulfate (green rust). Environ. Sci. Technol. 1999, 33, 307-311. [CrossRef]

151. Hansen, H.C.B.; Bender Koch, C.; Nancke-Krogh, H.; Borggaard, O.K.; Sorensen, J. Abiotic nitrate reduction to ammonium: Key role of green rust. Environ. Sci. Technol. 1996, 30, 2053-2056. [CrossRef]

152. Hansen, H.C.B.; Guldberg, S.; Erbs, M.; Bender Koch, C. Kinetics of nitrate reduction by green rusts-Effects of interlayer anion and Fe(II):Fe(III) ratio. Appl. Clay Sci. 2001, 18, 81-91. [CrossRef]

153. Heasman, D.M.; Sherman, D.M.; Ragnarsdottir, K.V. The reduction of aqueous $\mathrm{Au}^{3+}$ by sulfide minerals and green rust phases. Am. Mineral. 2003, 88, 725-738. [CrossRef]

154. Kone, T.; Hanna, K.; Abdelmoula, M.; Ruby, C.; Carteret, C. Reductive transformation and mineralization of an azo dye by hydroxysulphate green rust preceding oxidation using $\mathrm{H}_{2} \mathrm{O}_{2}$ at neutral $\mathrm{pH}$. Chemosphere 2009, 75, 212-219. [CrossRef] 
155. Larese-Casanova, P.; Scherer, M.M. Abiotic transformation of hexahydro-1,3,5-trinitro-1,3,5-triazine (RDX) by green rusts. Environ. Sci. Technol. 2008, 42, 3975-3981. [CrossRef]

156. Lee, W.; Batchelor, B. Abiotic reductive dechlorination of chlorinated ethylenes by iron-bearing soil minerals. 2. Green rust. Environ. Sci. Technol. 2002, 36, 5348-5354. [CrossRef] [PubMed]

157. Legrand, L.; El Figuigui, A.; Mercier, F.; Chausse, A. Reduction of aqueous chromate by Fe(II)/Fe(III) carbonate green rust: Kinetic and mechanistic studies. Environ. Sci. Technol. 2004, 38, 4587-4595. [CrossRef]

158. Loyaux-Lawniczak, S.; Refait, P.; Lecomte, P.; Ehrhardt, J.-J.; Génin, J.-M.R. The reduction of chromate ions by Fe(II) layered hydroxides. Hydrol. Earth Syst. Sci. 1999, 3, 593-599. [CrossRef]

159. Mitsunobu, S.; Takahashi, Y.; Sakai, Y. Abiotic reduction of antimony(V) by green rust $\left(\mathrm{Fe}_{4}(\mathrm{II}) \mathrm{Fe}_{2}(\mathrm{III})(\mathrm{OH})_{12} \mathrm{SO}_{4} * 3 \mathrm{H}_{2} \mathrm{O}\right)$ Chemosphere 2008, 70, 942-947. [CrossRef] [PubMed]

160. Myneni, S.C.B.; Tokunaga, T.K.; Brown, G.E., Jr. Abiotic selenium redox transformations in the presence of Fe(II,III) oxides. Science 1997, 278, 1106-1109. [CrossRef]

161. O'Loughlin, E.J.; Burris, D.R. Reduction of halogenated ethanes by green rust. Environ. Toxicol. Chem. 2004, 23, 41-48. [CrossRef] [PubMed]

162. O'Loughlin, E.J.; Kelly, S.D.; Kemner, K.M.; Csencsits, R.; Cook, R.E. Reduction of $\mathrm{Ag}^{\mathrm{I}}, \mathrm{Au}^{\mathrm{III}}, \mathrm{Cu}^{\mathrm{II}}$, and $\mathrm{Hg}^{\mathrm{II}}$ by $\mathrm{Fe}^{\mathrm{II}} / \mathrm{Fe}^{\mathrm{III}}$ hydroxysulfate green rust. Chemosphere 2003, 53, 437-446. [CrossRef]

163. Pepper, S.E.; Bunker, D.J.; Bryan, N.D.; Livens, F.R.; Charnock, J.M.; Pattrick, R.A.D.; Collison, D. Treatment of radioactive wastes: An x-ray adsorption spectroscopy study of the treatment of technetium with green rust. J. Colloid Interface Sci. 2003, 268, 408-412. [CrossRef]

164. Refait, P.; Simon, L.; Génin, J.-M.R. Reduction of $\mathrm{SeO}_{4}{ }^{2-}$ anions and anoxic formation of iron(II)-iron(III) hydroxy-selenate green rust. Environ. Sci. Technol. 2000, 34, 819-825. [CrossRef]

165. Skovbjerg, L.L.; Stipp, S.L.S.; Utsunomiya, S.; Ewing, R.C. The mechanisms of reduction of hexavalent chromium by green rust sodium sulphate: Formation of Cr-goethite. Geochim. Cosmochim. Acta 2006, 70, 3582-3592. [CrossRef]

166. Williams, A.G.B.; Scherer, M.M. Kinetics of Cr(VI) reduction by carbonate green rust. Environ. Sci. Technol. 2001, 35, 3488-3494. [CrossRef] [PubMed]

167. Yan, S.; Boyanov, M.I.; Mishra, B.; Kemner, K.M.; O’Loughlin, E.J. U(VI) reduction by biogenic and abiotic hydroxycarbonate green rusts: Impacts on U(IV) speciation and stability over time. Environ. Sci. Technol. 2018, 52, 4601-4609. [CrossRef] [PubMed]

168. Etique, M.; Zegeye, A.; Gregoire, B.; Carteret, C.; Ruby, C. Nitrate reduction by mixed iron(II-III) hydroxycarbonate green rust in the presence of phosphate anions: The key parameters influencing the ammonium selectivity. Water Res. 2014, 62, 29-39. [CrossRef] [PubMed] 